\author{
UNIVERSIDADE DE SÃO PAULO \\ FACULDADE DE FILOSOFIA, LETRAS E CIÊNCIAS HUMANAS \\ DEPARTAMENTO DE LETRAS CLÁSSICAS E VERNÁCULAS \\ PROGRAMA DE PÓS-GRADUAÇÃO EM LITERATURA PORTUGUESA
}

\title{
A estética do labirinto: barroco e modernidade em Ana Hatherly
}

Claudio Alexandre de Barros Teixeira

E-MAIL: claudio.dan@gmail.com

Dissertação elaborada no Programa de pósgraduação em Literatura Portuguesa do Departamento de Línguas Clássicas e Vernáculas da Faculdade de Filosofia, Letras e Ciências Humanas da Universidade de São Paulo, para a obtenção do título de mestre.

Orientador: prof. dr. José Horácio de Almeida Nascimento Costa

V. 1

São Paulo

2009 


\section{UNIVERSIDADE DE SÃO PAULO}

FACULDADE DE FILOSOFIA, LETRAS E CIÊNCIAS HUMANAS

DEPARTAMENTO DE LETRAS CLÁSSICAS E VERNÁCULAS

PROGRAMA DE PÓS-GRADUAÇÃO EM LITERATURA PORTUGUESA

CLAUDIO ALEXANDRE DE BARROS TEIXEIRA

A estética do labirinto: barroco e modernidade em Ana Hatherly

v. 1

São Paulo

2009 


\section{Agradecimentos}

A

Horácio Costa, orientador e amigo, pelos comentários e referências que foram essenciais para a realização deste trabalho.

$\grave{A}$

CAPES - Coordenação de Apoio à Pesquisa, pelo apoio financeiro dado para a minha pesquisa, entre os anos de 2007 e 2008.

Aos professores Antônio Vicente Seraphim Pietroforte, Mário Lugarinho, Maria Esther Maciel, por todas as sugestões e comentários.

A

Ana Hatherly, pelo entusiasmo, diálogo e generosidade.

A

Regina, pela cumplicidade, carinho e convívio. 


\section{SUMÁRIO}



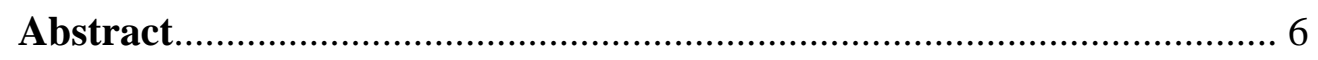

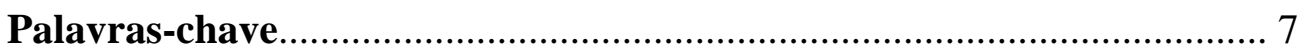



\section{Capítulo I: O labirinto contraria o linear}

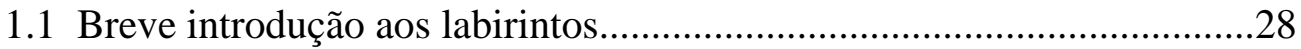

1.2 A obra labiríntica na modernidade......................................................42

1.3 O escritor: uma “máquina de produzir desordem”................................48

1.4 A reinvenção da escrita e da leitura.....................................................57

\section{Capítulo II: A escrita labiríntica das Tisanas}

2.1 As Tisanas: aspectos estruturais, conceituais e estilísticos....................64

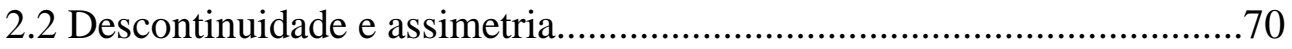

2.3 A “técnica da destruição da certeza”....................................................74

2.4 Diálogos entre a poesia e a pintura.....................................................78

2.5 As “proto-Tisanas” e as “Quase-Tisanas”.............................................82

2.6 Sonho, mito e criação poética...............................................................87

2.7 Leitura comparada: Anacrusa e Tisanas..............................................93

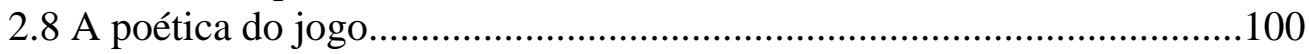

2.9 Leitura comparada: O mestre e Tisanas................................................106

Capítulo III: Vanguarda e pós-vanguarda na idade da escrita..............119

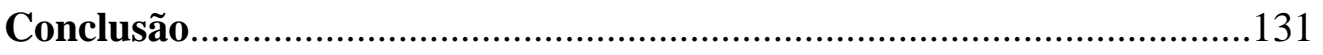

Referências bibliográficas.............................................................134 


\section{RESUMO}

A estética do labirinto: barroco e modernidade em Ana Hatherly tem como objetivo estudar a criação poética da autora portuguesa, apontando suas afinidades estéticas com as tradições barroca e maneirista, e em especial com os labirintos (ou textos visuais) do século XVII. Ana Hatherly, que integrou o movimento da Poesia Experimental Portuguesa (PO-EX), na década de 1960, fez uma releitura criativa dessa herança cultural, ao mesmo tempo em que dialogou com formas e procedimentos da vanguarda internacional (e em particular com a Poesia Concreta), visando a reinvenção da escrita, mesclando recursos da literatura, da música, da pintura e outras formas de expressão. A escrita renovada de Ana Hatherly demanda um outro tipo de recepção por parte do leitor, que participa da descoberta ou da construção de significados, numa reinvenção da leitura.

A estratégia criativa de Ana Hatherly aproxima-se, portanto, do conceito de obra aberta, formulado por Umberto Eco e Haroldo de Campos, que pode ser definida como um tipo de estrutura estética que permite múltiplas leituras, a partir de certo conjunto de regras estabelecidas pelo autor (que revela assim o aspecto de jogo da obra de arte). Este é um dos conceitos centrais discutidos na dissertação, aplicado à análise de obras da autora como as Tisanas, com apoio adicional nas formulações teóricas de autores como Affonso Ávila, Gustav R. Hocke e Johann Huizinga. Por fim, discutiremos os conceitos de vanguarda com base em autores como Marjorie Perloff, Renato Poggioli e Richard Kostelanetz, com o objetivo de apontar a atualidade de muitas das propostas do movimento da $P O-E X$, que não se limitam a um determinado contexto histórico, relacionando-se, inclusive, com experiências realizadas nos dias de hoje, no campo da poesia eletrônica ou digital. 


\begin{abstract}
The aesthetics of the labyrinth: baroque and modernity in Ana Hartherly aims to study the poetic creation of this Portuguese author pointing out its aesthetics choices in relation to the baroque and the mannerism, particularly the labyrinths (or visual texts) produced in the $17^{\text {th }}$ century. Ana Hatherly, who took part in the Portuguese Experimental Poetry movement (PO-EX), in the 1960's, performed a creative rereading of this cultural heritage, and at the same time established a link with forms and procedures of the international vanguard (especially with the Concrete Poetry), pursuing the reinvention of the writing, merging resources of literature, music, painting and other forms of expression. Ana Hatherly's renewed writing demands another way of approaching, one that leads the reader into discoveries or constructions of meanings, in a reinvention of the act of reading.

Ana Hatherly's creative strategy therefor is closely related with the concept of an open piece of work, formulated by Umberto Eco and Haroldo de Campos, and means a type of aesthetic structure that allows multiple interpretations, once a certain set of rules is established by the author (rendering, this way, a gamelike work). That is one of the key concepts to be discussed in this dissertation, where her works, such as Tisanas will be analyzed with additional theoretical support of works by Affonso Ávila, Gustav R. Hocke, and Johann Huizinga. Finally, we shall discuss the concepts of vanguard with theoretical support of Marjorie Perloff, Renato Poggioli and Richard Kostelanetz, aiming to point out how contemporary many of the PO-EX propositions are. Those are not bonded to a determined historical context, and even nowadays can be observed in experiences in the field of the electronic or digital poetry.
\end{abstract}


PALAVRAS-CHAVE: Ana Hatherly; experimentalismo; labirinto; visualidade; vanguarda.

KEYWORDS: Ana Hatherly; expermentalism; labyrinth; visuality; vanguard. 


\section{INTRODUÇÃO}

Ana Hatherly (Porto, 1929) faz uma releitura das tradições maneirista e barroca em sua poesia, ao mesmo tempo em que explora as possibilidades da invenção estética, mesclando recursos da literatura, da pintura, do desenho, da música e outros meios de expressão, situando-se no território das vanguardas da segunda metade do século XX.

O objetivo desta dissertação é investigar os processos criativos da autora — que participou ativamente do movimento da Poesia Experimental (PO-EX), na década de 1960 - relacionando a estrutura de seus textos com as formas da poesia barroca e com o conceito de obra aberta, formulado por Haroldo de Campos e Umberto Eco.

A estratégia criativa adotada pela poeta portuguesa recusa os conceitos habituais de “leitura” e “escritura” e incita a participação inteligente do leitor para a descoberta de múltiplas vias interpretativas, tal como ocorre na relação fruitiva com os labirintos poéticos, que a autora analisou em livros como A experiência do prodígio - bases teóricas e antologia de textos visuais portugueses dos séculos XVII e XVIII (1983).

Seguindo o ideal de reinvenção da escrita (e da leitura), ela incorporou procedimentos caligráficos, inspirada no estudo de alfabetos antigos como o chinês, o hebraico, o latino, e criou textos visuais em que as letras, sílabas e palavras são trabalhadas em função de aspectos plásticos, e não apenas semânticos, como acontece em obras experimentais situadas na fronteira entre a poesia, a narrativa e a pintura, como Anagramático (1970), Mapas da imaginação e da memória (1973) e O escritor (1975).

Conforme declara a autora no ensaio A reinvenção da leitura

Com essa tentativa experimentava, por um lado, alargar o campo da leitura para fora da literalidade; por outro, ainda, alargar o campo criador da própria escrita, metafórica e factualmente, pois que chamando a atenção para a escrita como desenho ou pintura de 
signos (tornando-a ilegível para desalojar do hábito da leitura conteudística) estava tentando restituir a escrita à sua força original, semiótica, icônica, autonomamente semântica (HATHERLY, Ana e MELO E CASTRO, E.M.: 1981, 149).

A recuperação do caráter visual da escrita em sua pesquisa poética, como declara Ana Hatherly em A casa das musas (1995), deriva tanto da Poesia Concreta e do Experimentalismo quanto do texto visual barroco, que apresentou a ela "a capacidade de desenvolver um novo modo de ler os textos, as imagens e tudo o que historicamente se nos oferece como leitura” (HATHERLY, 1995a: 12). “Quando falamos de escrita”, diz ela, “no contexto da literatura, falamos de texto, dum tipo de composição em que o processo de representação, a sua visualidade, se tornou de tal modo implícito que passou para a região da invisibilidade” (idem, 37). Ou seja, o sentido referencial da escrita se sobrepôs ao visual de tal maneira que este deixou de ser notado pela sensibilidade do leitor.

“É na segunda metade do século XX que a Poesia Concreta vem trazer para a área da escrita literária um contributo notável de insubordinação desse estado de coisas” (idem, 38), prossegue ela, citando ainda as contribuições de Mallarmé, Apollinaire, dos dadaístas, futuristas e surrealistas, que trouxeram "importantes modificações no conceito de leitura, que a partir de então deixa (de novo) de ser obrigatoriamente um percurso horizontal da esquerda para a direita, de cima para baixo. Desse processo de subversão e de liberação de energias, a visão da escrita saiu revigorada, reanimada, reinventada” (idem).

Conforme escreveu E. M. de Melo e Castro, “quase toda a Poesia Experimental Portuguesa produzida a partir do início da década de 60 se pode inscrever dentro de uma denominação geral de POESIA ESPACIAL” (HATHERLY, Ana, e MELO E CASTRO, E. M: 1981, 9), uma vez que “suas coordenadas visuais são dominantes” (idem). 
No cadinho das operações poéticas desenvolvidas pelos vanguardistas portugueses, prossegue Melo e Castro, "foi e é no campo das experiências visuais e espaciais do texto, considerado como matéria substantiva de que o poema se produz, que a pesquisa morfológica, fonética, sintática e semiológica se projetou e projeta” (idem).

Uma obra de Ana Hatherly que exemplifica a declaração de Melo e Castro e evidencia a releitura dos textos visuais maneiristas e barrocos dentro de uma perspectiva de vanguarda é o ciclo de variações poéticas Leonorana, que adota o mote de um conhecido vilancete de Camões, composto na métrica da redondilha maior ("Descalça vai para a fonte / Leonor pela verdura / vai formosa e não segura”).

Rogério Barbosa da Silva afirma que, nas 31 variações sobre o mote camoniano, a autora portuguesa dialoga com “vários aspectos imagéticos do texto de Camões”, que são “explorados e potencializados na tessitura sonoro-imagética, na espacialização dos versos e na própria inscrição gráfica” (SILVA, 2006). O diálogo com o texto camoniano, porém, evolui de um discurso sintático linear em que as referências intertextuais são claras até a progressiva fragmentação do verso, da palavra e do próprio alfabeto, culminando num abstracionismo gráfico que recorda obras como $O$ escritor.

O processo de dissolução do significante e do significado é descrito por Maria João Fernandes como uma "subversão da sintaxe, da semântica e da grafia da linguagem, uma invenção de novas formas de escrita e a exigência de novas formas de leitura, de uma participação ativa do leitor na decifração do texto” (HATHERLY, 2004: 74).

Ler e interpretar essa “composição híbrida, em que o verbal e o não-verbal se interpenetram” (SILVA, 2006) exige a compreensão de que estamos diante de um “jogo lúdico, racional e experimental, com todas as dimensões do signo: com a visual, com o som e com o sentido" (HATHERLY, 2004: 74). Temos aqui uma escrita reinventada, que 
participa tanto da tradição literária quanto da caligrafia, da tipografia, da música e da pintura.

Como observou Maria dos Prazeres Gomes, “o diálogo com a música dá-se não só ao nível da exploração dos estratos fônicos da língua, da exploração da tessitura sonora dos textos: trata-se de uma relação estrutural, homológica, uma relação de procedimentos” (GOMES, 1992), sintetizada na recombinação do mote camoniano numa série prismática de permutações. Recordemos que a variação é uma forma musical em que a melodia é repetida ao longo da composição com mudanças em seus "elementos constitutivos (como o ritmo, compasso, tonalidade, modo, harmonização, arabesco etc.), com a única e imperiosa condição de permitir que o ouvinte sempre possa reconhecer mais ou menos distintamente o tema original” (HOLLANDA, 1986: 1754).

Essa técnica musical, cujo exemplo mais conhecido são as Variações de Goldberg (1742), de Johann Sebastian Bach, é reimaginada por Ana Hatherly em Leonorana, onde as letras, palavras e frases funcionam como notas, acordes e ruídos que se combinam entre si como seqüências sonoras numa partitura, explorando as possibilidades de andamento, ritmo e harmonia, com as elipses funcionando como pausas e o branco da página como silêncio, integrado ao universo musical. A estrutura dos poemas obedece a uma lógica plástica e rítmica, decorrente da própria experiência da autora como musicista e artista visual.

Como é sabido, a pintura é uma experiência que acontece no espaço e a música se desenvolve no tempo; sendo assim, em Leonorana, Ana Hatherly realiza um fascinante entrecruzamento de recursos espaço-temporais que nos fazem lembrar de uma afirmação de Abraham Moles, para quem "as mensagens espaciais (desenho, pintura, por exemplo) são suscetíveis de um desenvolvimento temporal pela exploração que as decompõe em seqüências de elementos intensivos transmitidos numa ordem dada” (MOLES, 1969: 23). 
A espacialização das linhas e palavras integra a construção plástica do poema e direciona a oralização, em seus vários caminhos de leitura; o aspecto espacial da composição, portanto, colabora com o temporal, ou, para citarmos novamente Abraham Moles, “a utilização de artifícios tais como o corte ou a exploração de uma imagem numa sequência temporal permite traduzir artificialmente as dimensões espaciais” (idem, 33). A ambigüidade estrutural do poema, que se alimenta dos universos sonoro e visual, levou Melo e Castro a considerar que em Leonorana já não se trata "nem de música, nem de pintura, mas de novas articulações sintáticas que são a origem de outros novos sentidos, no seio de um sistema que a si próprio se considera poesia” (HATHERLY, 1992: 100).

A escolha de um texto clássico de Camões como célula-base para esse ciclo de variações não é casual; como observou Rogério Barbosa da Silva, um traço fundamental na poesia da autora portuguesa é “a sua relação crítica com o passado das várias tradições criativas que formaram o imaginário português e, de certa forma, o da cultura ocidental de que nos nutrimos”. (HATHERLY, 2004: 25) A poética de Ana Hatherly, continua Barbosa, “pressupõe não um rompimento com o passado - algo presumível de uma atitude de vanguarda (...) —, mas um trabalho de contínua releitura desse passado, com vistas a manter viva a chama de uma poesia inventiva” (idem). A própria autora portuguesa já escreveu que “inovar é sempre relativo e tanto se pode inovar com o novo como inovar com o antigo, porque a invenção é uma forma de reinvenção, toda a leitura é releitura e toda a releitura transforma” (HATHERLY, 1995a: 14).

A “relação crítica” com o passado a que se refere Barbosa é um ponto axial da Poesia Experimental (PO-EX), que identificou a “coincidência de vários processos criativos entre algumas criações poéticas barrocas e as atuais”, como diz Ana Hatherly em A casa das musas (HATHERLY, 1995a: 13), o que levou os experimentalistas a assumirem a defesa 
da poesia maneirista e barroca em seus manifestos e publicações. O número 1 da revista Poesia Experimental, de 1964, por exemplo, trazia poemas de Félix Krull, Quirinus Kuhlmann e Luís de Camões ${ }^{1}$ ao lado de autores vanguardistas da época.

Ana Hatherly confessa a “descoberta da surpreendente afinidade técnica que encontrei entre algumas das minhas composições dos anos 60 e algumas das criações medievais e barrocas com que nessa altura entrei pela primeira vez em contato” (HATHERLY, 1995a: 9), o que a motivou a fazer pesquisas sobre "a poesia visual européia, que desde os gregos alexandrinos ${ }^{2}$ se prolonga por toda a Idade Média, refloresce no Renascimento, explode no Barroco, mergulha no século XIX e renasce transfigurada no século XX” (idem). A revalorização do barroco histórico português, que remonta às análises críticas pioneiras de Jorge de Sena e Gaspar Simões, na década de 1950, foi então uma atitude contestadora em relação aos cânones da historiografia literária vigentes durante o regime salazarista, que sucumbiu com a Revolução dos Cravos, em 25 de abril de 1974. Conforme declara Ana Hatherly,

Os que defenderam a poesia barroca - como Melo e Castro e eu própria - fizeram-no por três motivos: 1) porque ela era condenada pela crítica oficial, e, assim, defendê-la era pôr em prática um programa de subversão; 2) porque se encontravam nos processos de criação da poesia barroca - visual ou não - valores processuais, retóricos e lúdicos que, tendo caído em desuso, à luz duma nova consideração surgiam como extraordinariamente dinâmicos e belos; 3) porque encontraram nessas obras paralelos idiossincráticos que ajudam a compreender algo da nossa estrutura mental e da nossa sensibilidade artística

\footnotetext{
${ }^{1} \mathrm{O}$ poema de Camões publicado na revista, intitulado Os chamados disparates da Índia, é uma crítica à administração colonial portuguesa no país asiático; podemos considerar que a escolha desse texto não foi casual, uma vez que, na época da publicação da revista, o regime salazarista esteve envolvido na repressão ao movimento pela emancipação política de Angola.

2 No ensaio A reinvenção da leitura, Ana Hatherly cita “os papiros mágicos do século V a. C. e o ‘Ovo’ de Símias de Rodes, que data do ano 300 a. C. e cuja técnica de leitura se conhece. Trata-se dum poema bucólico composto graficamente em forma de ovo, sendo essa forma usada como metáfora do processo poético. A sua leitura exige regras especiais: deve começar-se pela primeira linha superior, saltando depois para a última linha inferior, seguidamente retomando a segunda linha superior para descer à segunda inferior e assim sucessivamente até se atingir o centro” (HATHERLY, Ana, e MELO E CASTRO, E. M.: 1981,139).
} 
ainda hoje, uma visão diferente da idéia pós-moderna de neobarroco, que surgiu muito depois.” (idem, 13)

A revisão crítica do barroco português foi, portanto, um fenômeno simultâneo ao surgimento de uma poesia densa e hermética praticada por poetas da década de 1960, como Salette Tavares, Herberto Helder, Ana Hatherly, Luiza Neto Jorge, Ruy Belo e António Ramos Rosa, entre outros, que podemos alinhar numa vertente neobarroca da poesia portuguesa. Estes autores, embora tenham escrito e publicado seus poemas isoladamente (antes de constituírem grupos como a PO-EX e Poesia 61), apresentavam, já no final da década de 1950, uma afinidade de processos criativos.

Conforme escreveu Melo e Castro na edição n. 4/5 da revista Claro Escuro ${ }^{3}$, esses poetas se caracterizavam por "um tratamento específico da linguagem; uma maneira sui generis de produzir metáforas; uma articulação não imediatamente descritiva; uma enunciação que denotava distanciamento do sujeito lírico” (MELO E CASTRO, E. M., 1990: 75), sinais distintos, ou mesmo antagônicos ao discurso linear de conteúdo social do NeoRealismo e também ao lirismo intimista e sentimental do grupo articulado em torno da revista Presença. Na poesia dos jovens autores portugueses, continua, verificava-se uma

opacidade imagística que criava uma atmosfera encantatória na leitura, mas que pouco tinha a ver com o onirismo dos surrealistas: uma sensibilidade mais visual do que conceitual; uma relação mais sensual que ideológica com a escrita; um gosto pela invenção e pelo além do comum e também um novo rigor, talvez contraditório, sempre presente na concepção de estrutura do poema (idem).

Podemos reconhecer estas características em obras como A colher na boca, de Herberto Helder (1960), Quarta dimensão (1961), de Luiza Neto Jorge, Viagem através de uma nebulosa (1960), de António Ramos Rosa, Boca bilíngüe (1966), de Ruy Belo, ou A dama e o cavaleiro (1960), de Ana Hatherly. O neobarroco português incorporou o espírito

\footnotetext{
${ }^{3}$ Texto republicado em livro com o título O fim visual do século XX. São Paulo: Edusp, 1993.
} 
lúdico, imagético, sensorial da arte setecentista, mas nada tinha a ver com “as implicações

históricas e religiosas do século XVII”, segundo Melo e Castro, que identificou como

pontos de contato a "busca fonética, da pesquisa lingüística, da investigação da estrutura do

poético, da reformulação da sintaxe e do alargamento do âmbito semântico, ou do aumento

da temperatura informacional dos textos” (MENÉRES e MELO E CASTRO, E. M. 1971: XLIX).

Conforme escreveu Vincenzo Russo,

O barroco, longe de ser entendido nos seus aspectos sociológicos de época ou de cultura da Contra-Reforma, da Inquisição, do Jesuitismo, transforma-se, na ressemantização dos poetas da década de 60 e 70 em Portugal, numa arma de resistência e de luta contra o regime salazarista, que pode apenas reevocar o Seiscentos na comum característica de serem ambos períodos sem liberdade de expressão. Aos poetas experimentalistas, para citar Melo e Castro, não interessava o período histórico em si, dos séculos XVII e XVIII, mas sim a potencialidade dinâmica da idéia de barroco, sobretudo à luz de uma perspectiva construtivista-combinatória, centrada quase exclusivamente nas suas vertentes lúdico-formalistas e concreto visuais. (RUSSO, 2008: 97)

O conceito de um barroco cíclico, transistórico, que surgiria em momentos da

história saturados de classicismo remonta a teóricos como Ernst Curtius, Gustav Hocke e

Eugênio D’Ors e sua aproximação com as teses e propostas da vanguarda pode ser situada

nas décadas de 1950 e 1960, graças ao trabalho de autores como Umberto Eco e Haroldo de

Campos. No ensaio VER-TER-SER, Melo e Castro escreve o seguinte comentário:

A recusa de modelos estáticos é uma dimensão da arte de vanguarda e por aqui se pode fazer uma aproximação com a dinâmica barroca. É que o barroco tem um significado de dinamização e abertura e desprende-se de um período histórico datado. Se procurarmos cuidadosamente, encontraremos características de atividade de tipo barroco em todos os períodos da História em que o equilíbrio das formas e das fórmulas perfeitas e o estatismo das certezas dão lugar ao dinamismo das dúvidas e das perguntas, ao plurissignificado das formas, à crescente quantidade de informação contida nos sinais, à ambigüidade viva dos símbolos, ao espaço sensível das hipóteses, às formas dinamizadas na sua própria ascensão ou queda, ao ornamento estruturalmente funcional, à luz que potencializa os volumes, à sombra que define ou dilui gestalticamente o fundo e a figura, às palavras em movimento que inventam as idéias, às metáforas e aos objetos em diálogo de informação mútua, à redução e rigor matemático do aleatório, contra os cânones rígidos da beleza. É por tudo isto que é preciso estudar e compreender o barroco, não como mero período histórico mas sim como idéia mestra oposta à idéia de 'clássico', definindo um dos dois modos de o homem estar no mundo, viver, criar e comunicar. (HATHERLY, Ana, e MELO E CASTRO, E. M., 1981: 163-164) 
O livro de estréia de Ana Hatherly, Um ritmo perdido, publicado em 1958, embora seja anterior às pesquisas visuais da autora, já apresenta elementos barroquizantes, como a construção de metáforas, enigmas e paradoxos, mesclados a elementos da tradição lírica portuguesa. No poema que dá título ao volume, encontramos a seguinte estrofe, em que ela faz um irônico auto-retrato a partir de sucessivas negações e jogos antitéticos entre seres animados e inanimados, concretos e abstratos, reais e mitológicos: “Não vês que eu não sou nada, / nem anjo nem pessoa, / nem ave nem engenho, / Que é totalmente outra / A minha definição? / Eu não sou mais do que o próprio chão...” (HATHERLY, 1980: 25).

O tema de uma outra identidade, fingida ou sentida, tem ecos de Fernando Pessoa e Sá-Carneiro — antecedidos pelo Sá de Miranda das Trovas à maneira antiga: “Comigo me desavim / sou posto em todo perigo: / não posso viver comigo / nem posso fugir de mim” - (SPINA, 1974: 185) e prossegue na obra seguinte, As aparências (1959), em que encontramos os versos: “A viagem que o meu ser empreende / Começa em mim, / E fora de mim, / Ainda a mim se prende. // A senda mais perigosa / Em nós se consumando, / Passamos a existência / Mil círculos concêntricos / Desenhando” (HATHERLY, 1980: 27).

Os deslocamentos entre dentro e fora, real e imaginário, sentido e pensado, significante e significado, sujeito real e o outro construído são elementos essenciais na lírica de Ana Hatherly, assim como as palavras tempo, espelho, sonho e viagem, que indicam relações intertextuais com o imaginário e a simbologia do barroco ("La vida es sueño”) e também da filosofia budista, que compara a existência mutável e impermanente com a natureza irreal do sonho (tópico que será desenvolvido no segundo capítulo deste trabalho).

O teatro ilusório do mundo é representado de maneira enfática em outra peça de As aparências, intitulada Quando bebeu o elixir perdeu a dimensão, que em sua terceira seção 
diz: “O sonho é a ponte / Que vai do infinito ao infinito, / É a medida sem comparação, / É a presença do que se imagina. // Sonhar talvez só seja / Reconhecer o que já nem a alma sinta / Nem o próprio pensamento veja” (HATHERLY, 1980: 26). Nestas linhas, observamos jogos entre elementos concretos (ponte) e abstratos (sonho), o uso da anáfora (do infinito ao infinito), da sinestesia (alma sinta / pensamento veja), do paradoxo (medida sem comparação) e outras figuras tradicionais da retórica, que funcionam como elementos de forte contraste expressivo. Segundo Vincenzo Russo, o neobarroco português incorporou, de maneira intertextual, os “materiais barrocos” por meio de “formas de citação, de releitura, de colagem, de transposição, de paródia” (RUSSO, 2008: 105), provocando uma “des-historicização pós-moderna dos mesmos materiais, cujo uso já não necessita de ser legitimado pelo seu conteúdo histórico”, sendo “regulamentado por estruturas imanentes ao próprio contexto estético”, seguindo uma estratégia artística “centrada quase exclusivamente nas suas vertentes lúdico-formalistas e concreto-visuais” (idem).

A releitura do passado pelos experimentalistas, portanto, foi uma revisão criativa do repertório da tradição barroca e maneirista, buscando recuperar o que ainda havia de informação nova ou pouco assimilada, dentro de uma perspectiva de vanguarda. A revisão crítica do barroco não se confunde com o pastiche de estilos históricos pela pósmodernidade, afirma Guy Scarpetta, por sua “exigência de invenção, de estilo”, enquanto o pós-modernismo, "tal como o kitsch, poderia definir-se como a incapacidade de criar um estilo, e pela pura substituição da invenção pela citação” (PEREIRA, Paulo, 1990) . O

\footnotetext{
${ }^{4}$ Eduardo Milán faz crítica similar ao pós-modernismo em seu artigo Poesia: questão de futuro, onde afirma: "Partindo da base de que os laços com o passado estão rompidos definitivamente, vai buscar ali os cumes eufóricos desse tempo, os momentos de maior prestígio — não os de maior temperatura estética - e, em um efeito de mímese atemporal, 'recupera' para o presente os momentos de opulência de um tempo que já nada tem a ver com o passado, nem com um presente que derive dele. Deste modo, se des-historiciza o passado e, em conseqüência, também o presente” (MILÁN, 2001: 75).
} 
neobarroco seria uma “conciliação com a modernidade”, diz Paulo Pereira, ou ainda “a vanguarda ela mesma na impossibilidade de se ser vanguarda.” (idem).

O neobarroco português, desde o seu surgimento, se definiu como vanguardista e próximo às propostas do movimento internacional da Poesia Concreta, como declara Melo e Castro na coletânea PO-EX - Textos teóricos e documentos da poesia experimental portuguesa, em que aponta os dois acontecimentos principais que antecederam o aparecimento em Portugal de manifestações da Poesia Experimental:

primeiro, a rápida visita a Lisboa de Décio Pignatari em 1956 (sem resultados significativos) após o seu já histórico encontro com Gomringer; segundo, a publicação em 1962, pela Embaixada do Brasil em Lisboa, de uma pequena mas excelente compilação da Poesia Concreta do Grupo Noigandres - São Paulo - Brasil (ano em que eu próprio publico IDEOGRAMAS, reunindo poemas de 1961). (MELO E CASTRO, E. M., e HATHERLY, Ana: 1981, 9).

Ana Hatherly, aliás, publicou em 1959 o primeiro poema concreto escrito em Portugal $^{5}$ (que pode ser lido em várias direções, como um labirinto barroco), mas a sua adesão ao movimento internacional da Poesia Concreta só aconteceu em 1966, quando colaborou no $2^{\circ}$. número dos Cadernos da Poesia Experimental Portuguesa, assumindo, a partir daí, a liderança da tendência experimentalista, ao lado de Melo e Castro. Os poemas concretistas de Ana Hatherly, produzidos entre 1959 e 1964, foram incluídos na antologia Um calculador de improbabilidades (2001), que reúne textos criativos da autora.

A relação de Ana Hatherly com a Poesia Concreta, no entanto, logo manifestou sinais de esgotamento. Segundo a poeta, “são poucos os exemplos de um concretismo ortodoxo por mim praticado porque em breve me apercebi da rapidez com que esse processo, extremamente redutor, se esgotava, podendo conduzir a uma ociosa tautologia”

\footnotetext{
${ }^{5}$ Ana Hatherly publicou também o primeiro artigo sobre a Poesia Concreta que saiu em Portugal, no suplemento Letras e Artes do jornal Diário de Notícias, em 1959.
} 
(HATHERLY, 2001: 10). Apesar da recusa em prosseguir escrevendo poemas conforme os postulados do Plano-piloto da poesia concreta, Ana Hatherly reconhece seu aprendizado com esse processo, que integrou posteriormente em outras experiências, “quer na poesia visual, quer na exploração analítica de formas tradicionais do discurso poético, inclusive na sua aproximação à prosa, sobretudo ao poema em prosa” (idem).

Ana Hatherly realizou experiências inventivas com a prosa poética nas suas Tisanas, em que a autora coloca em primeiro plano a ambigüidade, a assimetria, o hibridismo, o non sense, dialogando com as fábulas tradicionais do zen-budismo, conhecidas como koans, que perturbam a lógica rotineira pela ação fabulatória inesperada e inusitada. Esse livro, iniciado em 1969, é um work in progress que dispensa a noção de unidade narrativa e a seqüência linear início-meio-fim, incitando o leitor a construir o seu próprio caminho de leitura nesse conjunto de textos labirínticos que desconsideram distinções entre gêneros literários (assim como o romance experimental O mestre, de 1963, e o diário de sonhos Anacrusa, de 1983).

A participação criativa do leitor na construção de rotas interpretativas do texto é um dos elementos centrais da concepção das Tisanas $^{6}$, assim como ocorre nos labirintos barrocos e em obras de vanguarda como o Un coup de dés de Mallarmé, os Cantos de Pound e o Finnegans Wake de Joyce. Neste sentido, podemos considerar as Tisanas uma obra de arte aberta, conceito apresentado por Haroldo de Campos $^{7}$ em artigo publicado no

\footnotetext{
${ }^{6}$ Roland Barthes, ao fazer uma distinção entre texto lisible (“legível”) e scriptible (“escritível”), define o segundo como "uma galáxia de significantes, não uma estrutura de significados; ele não tem começo; é reversível; conquistamos o acesso ao mesmo através de várias entradas, nenhuma das quais pode se declarar, de modo autorizado, ser a principal” (PERLOFF, 1993: 272). Esta definição, a nosso ver, define bem a concepção e a estrutura das Tisanas de Ana Hatherly.

${ }^{7} \mathrm{O}$ artigo de Haroldo de Campos, intitulado A obra de arte aberta, foi incluído na coletânea Teoria da poesia concreta - textos críticos e manifestos, 1950-1960 (São Paulo: Duas Cidades, 1975).
} 
Diário de São Paulo, em 03/07/1955, e posteriormente utilizado por Umberto Eco na comunicação O problema da obra aberta, apresentado no XII Congresso Internacional de Filosofia, em 1958, e depois no livro Obra aberta, cuja primeira edição data de 1962.

Conforme escreveu Haroldo de Campos, a concepção estrutural do "poemaconstelação” Un coup de dés, de Stéphane Mallarmé, liquidou “a noção de desenvolvimento linear seccionado em princípio-meio-fim, em prol de uma organização circular da matéria poética” (CAMPOS, Augusto e Haroldo de, e PIGNATARI, Décio: 1975, 30), na qual o “elemento primordial de organização rítmica” é o espaço em branco da página, assim como o silêncio é parte integrante da música de Anton Webern. A variação tipográfica de fontes e corpos de letras, no poema de Mallarmé8 ${ }^{8}$, bem como o uso de itálicos e negritos, contribuem para dar uma variedade de ritmos, timbres e de altura — não por acaso, o poeta francês confessa a influência da “música ouvida em concerto” (MALLARMÉ, 1980: 152) na criação de seu poema, enquanto a disposição espacial das palavras e linhas em páginas duplas permite ao leitor diferentes formas de leitura ${ }^{9}$.

${ }^{8}$ Gerald L. Bruns, em Modern poetry and the idea of language, diz o seguinte sobre a importância estrutural da tipografia no poema de Mallarmé: "Em Un coup de dés, a tipografia substitui a sintaxe como um meio de estabelecer relações entre as palavras - isto é, como um meio de organizar o material do poema. As estruturas sintáticas são encontráveis em toda parte, mas elas são radicalmente difundidas pelo modo como as palavras estão colocadas na página” (PERLOFF, 1993: 175).

${ }^{9}$ E. M. de Melo e Castro, em texto lido na Feira do Livro de 1962, em Lisboa, afirma que Mallarmé, "ante a solicitação da página em branco, joga e concebe o poema como se de um jogo de dados se tratasse. Dados que no entanto nunca esgotam as possibilidades totais do acaso, deixando-as sempre intocadas e as mesmas, após a concretização de cada resultado. E termina o poema dizendo: cada pensamento, cada ato, cada imagem descobre e propõe uma jogada. Põe em equação todas as potencialidades da vida e apresenta um resultado livre, resultado que é válido em si próprio, mas não esgota as potencialidades nem da vida, nem de quem cria o poema, de quem encontra o resultado e o propõe. Por isso, cada poema é sempre um retorno ao começo. É sempre um trabalho de reinvenção do mundo" (HATHERLY, Ana, e MELO E CASTRO, E. M.: 1981, 99). Já no texto intitulado A Proposição 2.01, o autor volta ao tema do poema mallarmaico, dizendo: "Uma jogada de dados, embora defina um resultado (o Poema), não abole o acaso (como diz Mallarmé). Os dados, no ar, contêm todas as possibilidades de significação — uma vez caídos sobre a mesa definem um resultado — mas um só - para sempre - e só por aquele instante, pois a próxima jogada já será diferente. A próxima jogada fica sempre em aberto. E esse é o trabalho do Poeta como artista criador” (idem, 123). 
O princípio da obra aberta está presente também no Finnegans Wake de James Joyce, uma obra "que retém a propriedade do círculo, da eqüidistância de todos os pontos em relação ao centro: a obra é porosa à leitura, por qualquer das partes através das quais se procure assediá-la” (CAMPOS, Augusto e Haroldo de, e PIGNATARI, Décio: 1975, 31). Neste livro de alta radicalidade inventiva, a junção neológica de termos históricos, geográficos, científicos, mitológicos, nomes próprios ou de uso comum (riverrun, devlinsfirst, viterberated, por exemplo) multiplica a geração de significados "a ponto de conter todo um cosmos metafórico numa só palavra” (idem). No ensaio Panorama em português, que escreveu para o livro Panaroma do Finnegans Wake, Haroldo de Campos acrescenta:

Ninguém como Joyce levou a tal extremo a minúcia artesanal da linguagem. Seu macrocosmo - seu romance-rio - traz, em quase cada uma das unidades verbais que o tecem, implícito um microcosmo. A palavra-metáfora. A palavra-montagem. A palavraideograma. (...) No Finnegans Wake abole-se o dualismo fundo-forma em prol de uma dialética perene de conteúdo-e-continente, de um onipresente isomorfismo: se o entrecho é fluvial, nomes de rios se imbricam nos vocábulos, criando um circuito reversível de reflexos do nível temático ao nível formal. (JOYCE, 2001: 27-28)

As novas estruturas composicionais citadas por Haroldo de Campos em seu artigo — que menciona ainda a poesia de Cummings, os Cantos de Pound, a música de Webern, as esculturas móveis de Calder — teriam poucas afinidades estéticas ou conceituais com a “obra de arte 'perfeita’, 'clássica', do ‘tipo diamante’”, segundo definições de Pierre Boulez, aproximando-se antes de uma "concepção de obra de arte aberta, como um barroco moderno” (CAMPOS, Augusto e Haroldo de, e PIGNATARI, Décio: 1975, 33).

Formas circulares, não-lineares de composição, que favorecem a multiplicidade de leituras, como as de Mallarmé, Joyce ou Pound, criam uma nova relação entre o receptor e a mensagem, tema que Umberto Eco desenvolveu em seu livro de 1962. Segundo o autor italiano, “a atenção deverá deslocar-se da mensagem como sistema objetivo de informações 
possíveis para a relação comunicativa entre mensagem e receptor, (...) na qual a decisão interpretativa do receptor passa a constituir o valor efetivo da informação” (ECO, 2008: 5).

No prefácio que escreveu para a edição de 1968 do livro de Eco, Giovanni Cutolo observa que o autor “sustenta um ‘modelo teórico’ de obra aberta”, que não reproduz “uma presumida estrutura de uma relação fruitiva, isto independentemente da existência prática, factual, de obras caracterizáveis como ‘abertas’” (ECO, 1976: 9). O que o pensador italiano propõe a seus leitores, prossegue Cutolo, não é “o 'modelo' de um dado grupo de obras, mas sim de um grupo de relações de fruição entre estas e seus receptores” (idem). Quando o espectador manuseia uma escultura da série Bichos, de Lygia Clark, por exemplo, ele estabelece uma relação com a obra de arte distinta da contemplação de uma tela de Michelangelo ou Leonardo da Vinci: ele manipula a obra, altera sua forma, cria um sentido para ela, dentro das possibilidades oferecidas pelo próprio objeto artístico.

A estrutura da obra aberta, afirma Eco, é um “sistema de relações (...) entre seus diversos níveis (semântico, sintático, físico, emotivo; nível dos temas e nível dos conteúdos ideológicos; nível das relações estruturais e da resposta estruturada do receptor etc.)” (idem, 28), e é a pluralidade de interpretações possíveis derivada dessas relações fruitivas que sinaliza a "riqueza de aspectos e ressonâncias" (idem, 40) de uma obra, que nunca deixa de ser ela mesma. “Cada fruição, assim, é uma interpretação e uma execução”, diz o autor italiano, "pois em cada fruição a obra revive dentro de uma perspectiva original” (idem).

O modelo teórico proposto por Eco altera a forma tradicional de interpretação do texto literário, em que o sentido era estabelecido pelo autor e pelo próprio texto, cabendo ao leitor apenas recebê-lo. Se a liberdade oferecida pela obra aberta enriquece a construção de significados, pela participação ativa do leitor, por outro lado implica o risco de leituras 
dispersivas e caóticas, distantes do "modo com que o próprio texto prevê essa participação” (ECO, 2008: 2), como o autor reconheceu, posteriormente, em Os limites da interpretação, publicado em 1990 (logo, quase três décadas após Obra aberta). Isto equivale a dizer, nas palavras do próprio Eco, que “o texto interpretado impõe restrições a seus intérpretes. Os limites da interpretação coincidem com os direitos do texto (o que não quer dizer que coincidam com os direitos de seu autor)” (idem, XXII).

Temos aqui, portanto, a seguinte questão teórica: como conciliar a liberdade de leitura da obra aberta com o sentido original do texto?

Uma das possíveis respostas a esse desafio é a adoção de um conjunto de regras, ou programas, para a obra experimental. Melo e Castro escreveu que "são programas o cálculo combinatório e as formas geométricas em que se baseiam os labirintos barrocos e, antes deles, os poemas figurativos medievais. São programas a estrutura métrica e rímica do soneto, da décima, da sextina...” (HATHERLY, 1992: 99). Isto significa que a construção formal do poema traz um sentido estrutural e os caminhos para sua leitura e interpretação.

Por esse motivo, “um dos princípios basilares de todo o Experimentalismo”, diz Ana Hatherly, “é o da concepção e aplicação de um programa, que valida e fundamenta todo o processo criativo, desde a concepção à execução” (HATHERLY, 1995a: 10). A poeta portuguesa parte de uma estratégia e de um método para estabelecer um pacto lúdico com o leitor, conciliando a organização da obra poética com a liberdade interpretativa. No livro Um calculador de improbabilidades, Ana Hatherly afirma que

A consciência dos mecanismos da criação e da comunicação, que se procura atingir através do ato poético, está submetida às regras que o poeta a si próprio impõe e que são as normas do jogo que ele executa e persegue com idéias, palavras e atos. Nesse contexto, o criador surge como um investigador de formas e de sentidos, que são as 
improbabilidades $^{10}$ que ele calcula. O poema, como objeto-ato, é o resultado de um conjunto de regras aplicadas a uma situação específica. (HATHERLY, 2001: 8)

No ciclo de variações poéticas Leonorana, por exemplo, ela incluiu um programa que "rege a complexa combinatória que o texto documenta, entre elementos formais, semânticos e sonoros, incluindo a passagem para a visualização”, conforme Maria João Fernandes (HATHERLY, 2004: 74). Um exemplo deste programa é o comentário da autora sobre a Variação III de Leonorana: “Síntese da 1ª e 2a Variações com leituras múltiplas” (HATHERLY, 2001: 194). A descrição apenas indica as intenções formais do poema, dividido em três colunas que podem ser lidas separadamente, em sentido vertical, como na escrita chinesa, ou a partir de deslocamentos em diagonal da coluna central para as da esquerda e da direita, de cima para baixo ou de baixo para cima, em seqüências livres.

Assim, podemos construir múltiplas vias de leitura, a partir da indicação dada pelo programa, tais como: "leonor / nua / irmã / da formosura / das fontes / da verdura"; “quando / leonor / acordou / pela manhã / estava / nua”; entre outras. O poema convida o leitor a combinar as palavras em qualquer ordem ou dinâmica de leitura, tornando-se assim um hiper-anagrama: o princípio da metamorfose está presente na ordenação geral de todo o poema. No programa que escreveu para a Variação X, Ana Hatherly faz a seguinte descrição de procedimentos: “A ininteligibilidade torna-se significante por sonorização harmônica. Semantização da forma” (idem). O poema a que se refere este comentário é construído a partir de permutações de sílabas extraídas de palavras do mote camoniano e de

\footnotetext{
${ }^{10} \mathrm{O}$ conceito de improbabilidade empregado por Ana Hatherly é similar ao de Abraham Moles, que no livro Teoria da informação e percepção estética afirma: "Para medir a originalidade a priori de uma situação, o único comportamento que o raciocínio lógico nos oferece é contar com a improbabilidade dessa situação. Com efeito, a certeza de ocorrência de uma mensagem ou de um acontecimento dado nada ensina ao receptor e não pode modificar seu comportamento. (...) Diremos portanto que a informação ou a originalidade é função da improbabilidade da mensagem recebida.” (MOLES, 1969: 41)
} 
outras incluídas pela autora, recombinadas de maneira puramente sonora e abstrata, formando termos como onorante, velavai, alsaagem, aiorsura.

É possível verificarmos, nessa poesia planejada entre o logos e o acaso, o interesse de Ana Hatherly "pelo virtuosismo barroco ou pelas possibilidades da lógica combinatória, as quais permearam tanto o barroco quanto o surto estruturalista dos anos 60 e 70 ” (HATHERLY, 2004: 26). Entre os teóricos da poética estrutural, a autora portuguesa sempre manifestou o seu particular interesse por Abraham Moles, para quem a arte permutacional “permite realizar a variedade na uniformidade” (HATHERLY, 1995a: 11). Um recurso privilegiado para a permutação, utilizado por Ana Hatherly em diversas obras poéticas e visuais, é justamente o anagrama $^{11}$, incorporado no próprio título do livro em que estão inseridas as variações camonianas: Anagramático. O nome dado ao volume, aliás, é uma palavra-valise, assim como Tisanas, Rilkeana, Joyceana e outros livros em que a autora introduz o próprio nome, convertido em “assinatura extra” ou “impressão digital”, como declarou em entrevista a Pedro Sena-Lino (HATHERLY, 2004: 142).

O uso do anagrama como princípio estrutural permite ao poeta trabalhar com a “manipulação criativa dos efeitos da simultaneidade para a produção de textos destinados a uma leitura não linear, mas plúrima”, conforme escreveu Haroldo de Campos (CAMPOS, 1976: 111-112). Se no campo microestético o anagrama opera um desdobramento semântico, ou proliferação de termos a partir da recombinação de letras e fonemas, no campo macroestético ocorre fenômeno similar, com a multiplicação de arranjos

\footnotetext{
${ }^{11}$ Convém recordar aqui o interesse manifestado por Ferdinand de Saussure pela técnica do anagrama em seus estudos de poesia latina, védica e germânica. Conforme o lingüista francês, esse procedimento subverteria a "linearidade do significante do signo lingüístico" (CAMPOS, 1976: 110) em favor da polifonia e da simultaneidade, cuja relação com a música é evidente.
} 
construtivos de palavras, linhas, estrofes, grafismos e direções de leitura, conforme analisaremos, detalhadamente, ao longo da dissertação.

No primeiro capítulo, faremos uma breve exposição diacrônica sobre a história e o conceito dos labirintos, forma arquitetônica de caráter simbólico que influenciou os textos visuais maneiristas e barrocos; em seguida, estudaremos a forma e a concepção dos labirintos poéticos portugueses dos séculos XVI e XVII, que incorporavam recursos como o anagrama, o acróstico e o hieróglifo, dentro de uma concepção rigorosa de construção. Posteriormente, discutiremos obras capitais da modernidade como o Livro inacabado de Mallarmé, o Finnegans Wake de Joyce e outros textos que, por seu caráter plurívoco, permitem a multiplicidade de leituras. A comparação estabelecida neste capítulo entre os textos visuais barrocos e as obras da vanguarda têm como apoio teórico as formulações de Haroldo de Campos e Umberto Eco sobre a obra aberta. Por fim, analisaremos algumas obras de Ana Hatherly, como O escritor e Mapas da imaginação e da memória, que estão relacionadas com o conceito da obra aberta e com a estética dos labirintos.

No segundo capítulo, falaremos sobre três livros de prosa inventiva de Ana Hatherly — 463 Tisanas, Anacrusa e $O$ mestre, em que a autora realiza outro tipo de experiência com a linguagem, substituindo a estrutura visual por procedimentos textuais como ambigüidade, a assimetria, o hibridismo, a paródia e a quebra de fronteiras entre poesia, narrativa e outras formas de expressão (inclusive o sonho, considerado uma modalidade narrativa por Jorge Luis Borges). Estas obras não são labirintos no sentido tradicional, uma vez que não têm a configuração gráfica nem o programa dos textos visuais barrocos, mas o seu mecanismo de interpretação segue por uma via labiríntica, ao prescindir de uma linearidade própria das narrativas clássicas e convidar a capacidade imaginativa do leitor para a descoberta ou invenção de diversos caminhos de leitura, como 
na obra aberta. No estudo desses labirintos verbais, faremos uma aproximação entre elementos estéticos e conceituais do barroco e da vanguarda, com apoio no trabalho teórico de Umberto Eco, Affonso Ávila, Johann Huizinga e Gustav Hocke, entre outros.

Por fim, no terceiro capítulo faremos uma discussão sobre os conceitos de vanguarda, com apoio nas formulações de autores como Marjorie Perloff, Renato Poggioli e Richard Kostelanetz. O propósito deste tópico não é discutir apenas aspectos diacrônicos do movimento da Poesia Experimental Portuguesa (PO-EX), como se este fosse uma aventura intelectual datada e esgotada em suas possibilidades criativas, mas, ao contrário, mostrar os seus desdobramentos na época atual, com a poesia digital ou eletrônica. 


\section{CAPÍTULO I}

\section{O LABIRINTO CONTRARIA O LINEAR}

\section{1 - Breve introdução aos labirintos}

A palavra labirinto, escreve Jorge Luis Borges no Livro dos seres imaginários, vem do grego lábrys, ou machado de dupla lâmina, símbolo encontrado no palácio do rei Minos, na ilha de Creta, local identificado com o mítico labirinto projetado por Dédalo e habitado pelo Minotauro (BORGES: 1982, 98). Esta possível origem etimológica é aceita por dicionários e enciclopédias como The Tormont Webster's Illustrated Encyclopedic Dictionary (VÁRIOS AUTORES, 1990: 940) ou o Dicionário Oxford de Literatura Clássica Grega e Latina (HARVEY, 1987: 300), mas é contestada hoje por filólogos e etimologistas.

Segundo Carlos Rehermann, “na época da construção do palácio, o machado duplo era chamado peleky, e não lábrys, o que parece desarticular aquela teoria” (REHERMANN, 1999: 15). Com efeito, prossegue o autor, estudiosos como Isidoro de Sevilla derivam a palavra de labor (trabalho) e intus (lugar fechado), formando o termo grego labyrinthos, de onde provém o latino labyrinthus (idem). Assim, a palavra teria o sentido de "trabalho para sair (se o labirinto é uma prisão); trabalho para entrar (se o labirinto é uma proteção para um tesouro)” (idem). No primeiro caso, o centro dessa alegoria geométrica abriga um monstro; no segundo, é uma via para a vivência do sagrado, como ocorre na arquitetura simbólica do Cristianismo — e podemos recordar o labirinto da igreja de São Reparus, comentado por Ana Hatherly em A experiência do prodígio:

O mais antigo labirinto cristão que hoje se conhece parece ser o da igreja de São Reparus, em Orléansville, na Argélia, uma construção do século IV. Esse labirinto é quadrado, como os romanos, executado em pedras de cor, tem um diâmetro de cerca de três metros e está rodeado de numerosos emblemas, divisas, símbolos e sinais, e também, nas paredes, de painéis constituídos por labirintos de letras iguais, em estrutura, aos que encontramos ao longo de toda a Idade Média e depois, já durante o Maneirismo / Barroco, 
período ilustrado por exemplos portugueses da época e cuja leitura deve ser feita a partir do centro (HATHERLY, 1983a: 82).

Autores como Hermann Kerr, Carl G. Jung e Gustav R. Hocke estudaram o tema em suas conotações simbólicas, estéticas e culturais; o que nos interessa neste capítulo é investigar o labirinto como estrutura que propicia diferentes vias de significação, em paralelo com a teoria da obra aberta, para a análise do processo criativo de Ana Hatherly. Sendo assim, não faremos um levantamento exaustivo da variada gama de significados do labirinto, mas uma breve abordagem diacrônica para posterior análise estrutural.

Conforme demonstram as descobertas arqueológicas, as origens do labirinto remontam a cultos religiosos realizados em grutas, no período da pré-história, com manifestações posteriores no Egito, Grécia, Roma, Oriente e Europa cristã. Formas labirínticas foram encontradas na base de algumas pirâmides egípcias, na Acrópole, no teatro de Atenas, no túmulo de Augusto, em Roma. Segundo relata Gustav Hocke em seu livro O mundo como labirinto,

Heródoto descreveu um dos mais antigos labirintos do Egito. Tinha três mil quartos e, ao centro, quase impossível de localizar, escondiam-se os túmulos dos faraós e de crocodilos sagrados. Há ainda os relatos de Plutarco a respeito dos grandes feitos de Teseu, que construiu o maior de todos os labirintos: o de Cnossos, na ilha de Creta. Dédalo é o seu grande arquiteto. (Séculos mais tarde ele emprestará o seu nome ao herói do Retrato do artista quando jovem, de James Joyce) (HOCKE, 2005: 167) .

Os labirintos europeus eram circulares, quadrados, poligonais ou cruciformes e construídos em pedra, madeira ou ainda inseridos nos jardins, na forma de labirintos vegetais, como o construído em Nuremberg, em 1676. Gustav Hocke cita um curioso “labirinto óptico” projetado por Leonardo da Vinci, “formado por uma câmara octogonal, cujas paredes seriam todas revestidas por espelhos” (HOCKE, 2005: 14). 
Para o artista italiano, segundo Hocke, tratava-se apenas “do simbolismo abstrato e racional do infinito e das forças convulsivas que nele agem, sem destruir-lhe a ordem. Em seu centro, encontra-se o ser ‘enigmático’, o homem” (idem, 163). A representação geométrica destinava-se a “compreender o ‘enigma’ homem e seu mundo contraditório através de uma perspectiva anatural” (idem). Esta interpretação é derivada do espírito científico e humanista do Renascimento; em sua origem, porém, o labirinto tem uma natureza essencialmente religiosa.

Com sua teia de percursos intrincados que provocam desorientação ${ }^{12}$ ou terror no peregrino que se dispõe a atravessá-lo, o labirinto representa a confusão da alma imersa no mundo profano e também a jornada cuja meta é a conquista espiritual. “O labirinto”, afirma Ana Hatherly, "era a forma ideal para representar simbolicamente os perigos e as dificuldades de percurso que se deparam ao peregrino que tenta atingir a Jerusalém Celeste, a cidade de Deus, ou seja, a união com Cristo ${ }^{13 » ”(H A T H E R L Y, ~ 1983 a: ~ 83) . ~}$

Essa metáfora arquitetônica buscava “proporcionar simbolicamente ao homem um confronto consigo próprio através dum combate-percurso cujo objetivo é destruir o mal (se no centro estiver um monstro) ou alcançar a salvação (se no centro estiver a Igreja)” (idem,

12 “O vocábulo inglês maze (labirinto) significa também: admiração (stupore), estupefação diante do incompreensível” (HOCKE, 2005: 167).

13 A busca de um caminho de perfeição espiritual está presente também na mandala, forma circular que inclui em seu centro outras figuras geométricas, como o quadrado e o triângulo, simbolizando os mundos material e espiritual. Em Boro Budur, na Indonésia, há um conjunto de edificações budistas, erguidas no século VIII, que representam uma enorme mandala, percorrida por peregrinos à procura da purificação. Outra modalidade de labirinto do Extremo Oriente é o yantra, círculo "formado por dois triângulos que se interpenetram, um apontando para cima, outro para baixo", como relata Jung, em O homem e seus símbolos (JUNG, s/d: 240). O yantra, utilizado em práticas meditativas tântricas, simboliza a união de Shiva e Shakti, as divindades masculina e feminina, ou seja, da "união dos opostos - a união com o mundo impessoal e intemporal do não-ego. Concluindo, esta união é a consumação e o alvo de todas as religiões: é a união da alma com Deus”. 
87). Neste sentido, é “uma via iniciática de transmutação da consciência”, conforme diz o estudioso português Lima de Freitas (FREITAS, 1985: 70) ${ }^{14}$.

Os primeiros labirintos construídos pelas civilizações agrárias, em forma de espiral, eram unicursivos, diz Freitas, permitindo "um só percurso, sempre curvo, conduzindo fatalmente ao centro; as dificuldades de percurso ou do jogo labiríntico (recordemos que os jogos possuem origem divinatória ou sagrada) residem nos obstáculos, encontros perigosos, provas ou enigmas” que o peregrino deve vencer (idem, 69). Já os labirintos de base quadrangular das civilizações urbanas são multicursivos: “cada homem irá fazer a sua escolha no campo indefinido das possibilidades e das virtualidades”, não raro padecendo com “o erro, a perda do sentido, a desorientação” (idem, 70).

Em ambos os casos, nos labirintos unicursivos ou multicursivos, a decodificação se faz a partir do centro, que é “a questão verdadeiramente crucial da geometria dos labirintos”, pois constitui "um lugar estático e extático de morte e ressurreição, de confronto final e de prova última” (idem, 69). Nos labirintos cruciformes, ele é o ponto de intersecção entre a linha vertical e a horizontal, englobando "o superior e o inferior, o céu e o inferno, a luz e a sombra (...), ventre fechado e aberto de todos os mistérios.” (idem, 74).

A busca ou decifração desse centro fixo orienta todo o percurso de jornada arquetípica, e equivale à busca de um sentido na obra literária, em torno do qual se constrói a trama ficcional imaginativa, com múltiplas peripécias e jogos interpretativos.

Nos labirintos unicursivos, ainda que o percurso seja dificultoso, pelos obstáculos encontrados ao longo do caminho, ainda há certa linearidade, típica das narrativas clássicas,

\footnotetext{
${ }^{14}$ O próprio universo, segundo uma tradição que remonta a Plotino e recorrente na cultura medieval e barroca, seria um gigantesco labirinto poético criado por Deus para confundir os homens: um enigma cuja resolução equivale ao sentido da iluminação, já que o labirinto seria um espelho "onde se reflete a face do próprio arquiteto” (FREITAS, 1985: 71).
} 
uma vez que "prosseguindo-se na via até ao fim o centro é sempre atingido; prosseguindose ainda, percorre-se a espiral em sentido inverso e volta-se à entrada” (idem, 69). Essa linearidade é definida por Umberto Eco em seu comentário sobre as figuras alegóricas e emblemas medievais como a “poética do unívoco e do necessário”, subordinada a um “cosmo ordenado numa hierarquia de entes e leis” que o discurso poético "pode aclarar em mais níveis, mas que cada qual deve entender da única maneira possível, que é instituída pelo logos criador” (ECO, 1976: 43-44). Numa relação simbólica com o sistema político verticalizado, diz o autor italiano, a ordem da obra de arte medieval “é a mesma de uma sociedade imperial e teocrática; as regras de leitura são regras de um governo autoritário, que guiam o homem em cada um de seus atos”15 (idem).

Nos labirintos multicursivos, o aspecto lúdico e profano subverte a linearidade da jornada, oferecendo ao peregrino um amplo leque de trajetos: a univocidade teocrática cede vez a uma arquitetura plurívoca. Com efeito, o labirinto foi perdendo suas funções religiosas ao longo dos séculos, passando a ser valorizado como passatempo ou elemento decorativo nas villas romanas, como no famoso labirinto de Conímbriga (Figura 1).

A estrutura geométrica perdeu seu centro (sentido) simbólico: “uma vez eliminado esse centro mágico-místico, o caráter religioso do percurso dissolve-se, restando apenas o esqueleto racional, ou seja, o seu desenho, que, pela sua complexidade, se torna então apenas desafio à inteligência e à perícia: jogo” (HATHERLY, 1983a: 87).

O caráter lúdico da arquitetura labiríntica tem o seu equivalente literário nos textos visuais do barroco português, em que a pluralidade de leituras é obtida pela disposição

\footnotetext{
${ }^{15}$ Em sentido análogo, diz Freitas: “Na antiga vocação da Cidade como Cosmos o desenho labiríntico é bem o símbolo quadrangular de um percurso paradigmático, centrado e hierarquizado como o poder dos monarcas, ritualmente organizado como procissão coletiva que reproduz 'coreograficamente' os ritmos do Céu e da Terra, o mistério da encarnação dos deuses, os ciclos da vida, da morte e ressurreição.” (FREITAS,1985: 70)
} 


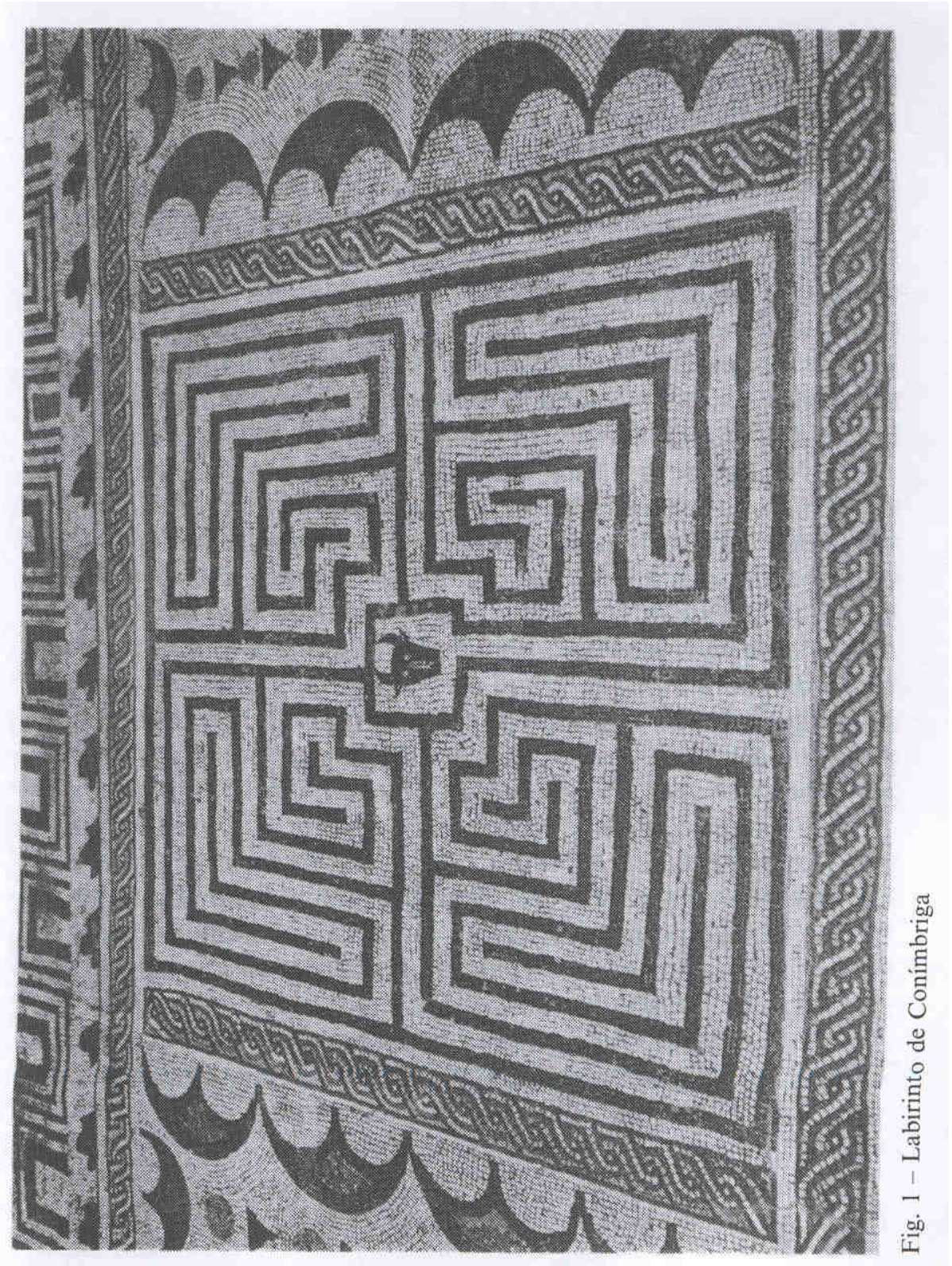

\section{Figura 1}

espacial das palavras e linhas e pelo emprego de recursos como o emblema, o acróstico, o anagrama, a "escrita diabólica” (texto redigido ao contrário, para ser lido no espelho), a figuração textual mimética de cálices, crucifixos, mapas celestes ou hieróglifos. Os labirintos poéticos, como esse gênero passou a ser conhecido, desenvolveram "um novo 
modo de ler os textos, as imagens e tudo o que historicamente se nos oferece como leitura” (HATHERLY, 1995a: 12), subvertendo o "percurso horizontal da esquerda para a direita, de cima para baixo. Desse processo de subversão e de liberação de energias, a visão da escrita saiu revigorada, reanimada, reinventada” (idem, 38).

O labirinto poético demanda não apenas o pensamento, mas sobretudo o olhar de quem o observa: “já não se trata de acompanhar um texto por uma imagem ou vice-versa, trata-se de produzir um texto que seja simultaneamente texto e imagem, numa só consistência, como acontecera na Antiguidade” (idem, 45).

Comentando os textos visuais do poeta latino Públio Optaciano Porfírio, do século IV, que inaugurou no Ocidente a tradição do labirinto, Ana Hatherly diz que, nesses poemas, “forma, cor, metro, signos constituem um tecido de relações tão interdependentes quanto vitais para a construção global do texto que, através da comunicação icônica, é concebido para funcionar a partir de um primeiro impacto visual” (idem, 74).

Esta definição poderia ser aplicada a um poema de 1743, como o Soneto acróstico esférico, de frei Francisco da Cunha (Figura 2), dedicado à rainha Maria Thereza da Áustria, cujo nome “determina a composição e a colocação dos versos” (idem, 48). Nesse labirinto, o centro é ocupado pela letra A maiúscula, e à sua volta são dispostos, de maneira circular, formas visuais, palavras e frases compostas a partir das letras do nome da soberana, que devem ser lidos da circunferência para o centro, num procedimento que incorpora o movimento rotatório ao ato da leitura.

A fusão híbrida de texto e imagem e a diversidade de vias interpretativas que verificamos nos textos visuais barrocos já se encontravam na escrita hieroglífica, nos pictogramas sumérios, nos ideogramas orientais, nos labirintos poéticos de Porfírio, nas technopaigniae gregas, nas carmina figurata medievais, nas composições renascentistas, 
mas é no barroco que alcançariam seu fulgor maior, quando, segundo Affonso Ávila, a forma artística "se abre em indeterminação de limites e imprecisão de contornos”, apelando para “os recursos da impressão sensorial”, não desejando apenas “conter a informação estética” (ÁVILA, 1994: 58). O poeta barroco visava comunicar a mensagem artística sob um grau de tensão que levasse o espectador "da simples esfera da plenitude intelectual e contemplativa para uma estesia mais franca e envolvente - mais do que isso, para um êxtase dos sentidos sugestionadamente acesos e livres” (idem).

Para obter esse efeito encantatório, diz Ávila, o poeta barroco adotou um "processo lúdico de encadeamento seja de formas plásticas, seja de palavras” (idem, 95). O caráter altamente sensorial do labirinto poético está presente não apenas em sua configuração visual, mas também na estrutura sonora: a repetição de uma frase, palavra ou mesmo de um fonema era "um elemento altamente significativo (...), reinserindo-se pelo menos em parte, na categoria dos mantras, das ladainhas, das litanias e das outras formas de oração encantatória” (HATHERLY, 1995a: 108-09).

A forte sugestão sonora e visual dos labirintos poéticos relacionava-se com uma visão mágica do mundo, resultante da "fusão do paganismo, do cabalismo e do hermetismo em geral, que estão na base dum complexo sincretismo filosófico e estético" (idem, 109), tendência cultural heterodoxa que atravessou a Idade Média e o Renascimento para desembarcar na cultura miscigenada do barroco, em que conviviam a ascese mística da fé católica, a herança de antigas heresias e religiões pagãs e a luxúria das formas de representação estética. A visão mágica do mundo é traduzida no labirinto poético pelo “simbolismo místico de sons, letras, números, formas geométricas” (idem), de onde podem ser extraídos "níveis de significação neles ocultos e sobrepostos (...) quer a sua intenção seja mágica, mística, laudatória ou simplesmente lúdica” (idem, 108). 


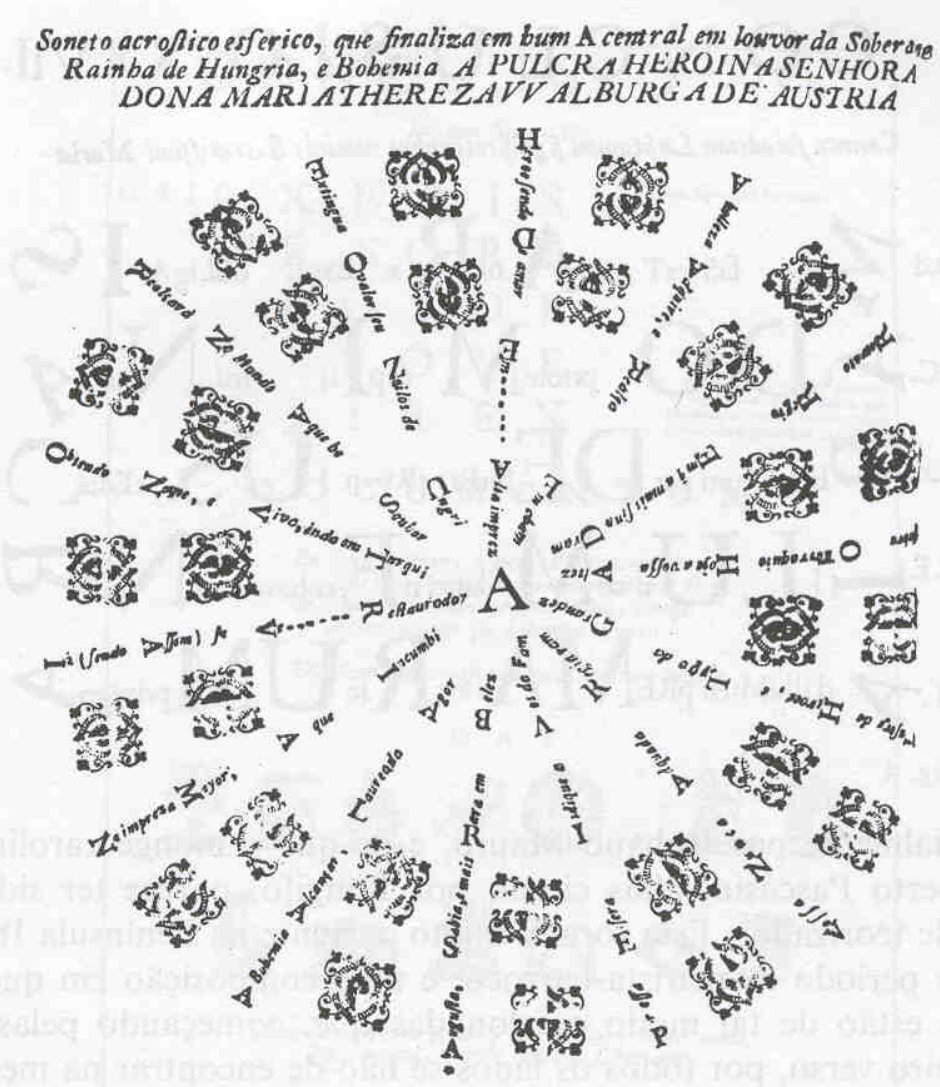

Fig. 3

Figura 2

Os labirintos, portanto, “são adivinhas, textos codificados para serem decifrados por um destinatário, contendo uma mensagem particular, independentemente da língua ou do sistema de línguas neles usados e qualquer que seja o tipo de mensagem transmitida” (idem, 107). Essas composições, diz Ana Hatherly, "refletem um gosto pelo intrincado e pelo rigor do pensamento científico, a que se alia um desejo de demonstrar capacidades excepcionais — espetaculares — geradoras de admiração e espanto” (idem, 95). Nos labirintos poéticos, as leituras podem ser feitas de baixo para cima, na diagonal ou ainda de modo similar ao movimento do cavalo no jogo de xadrez, permitindo assustadoras cifras de decodificação, que ultrapassam 14 mil combinações (idem, 56). A construção do labirinto poético, porém, não é arbitrária: ela obedece a "um conjunto de regras fixas que devem ser 
conhecidas tanto do autor como do leitor” (idem, 106), numa cumplicidade de referências culturais, "a fim de que esse possa decifrar, além da mensagem fornecida pelas palavras do texto, a mensagem implícita na correlação existente entre texto e estrutura, onde a profunda mensagem simbólica reside” (idem, 106-107). As regras de composição foram codificadas em tratados como a Arte poética española, de Juan Diaz Rengifo, e a Fuente de Aganipe o rimas várias, de Manuel de Faria e Souza, publicados no século XVI. No livro de Rengifo, lemos capítulos dedicados à criação de labirintos de versos, em que a multiplicidade de leituras é facilitada pela disposição espacial das linhas, e labirintos de palavras, em que as unidades semânticas são combinadas em diferentes seqüências.

Uma outra modalidade é o labirinto de letras, em que o poeta deve decidir "quais as letras que quer nos lugares que convém à formação das figuras que pretende compor”, diz Ana Hatherly em A casa das musas (idem, 47). Estes labirintos, segundo o tratado de Rengifo, podem assumir formas "en figura redonda, ò quadrada, ò pintando una ave, ò un arzol, ò una fuente, ò una cruz, ò uma estrella, ò outras figuras desta manera” (idem). O aspecto gráfico do labirinto de letras está diretamente relacionado com o princípio do acróstico, nome que designa "as composições poéticas nas quais certas letras formam uma palavra ou frase, no geral um nome próprio", que podem ser lidas "na vertical, de cima para baixo ou no sentido inverso”, segundo a definição de Massaud Moisés, em seu Dicionário de termos literários (MOISÉs, 2004: 11). O acróstico, diz Ana Hatherly, tem origem na "prática mágico-mística da escrita hebraica, que considera a meditação sobre o alfabeto como uma via para o conhecimento do nome das coisas e da criação, ou seja, o conhecimento de Deus” (HATHERLY, 1983a: 149). O Enigma de Sator, inscrição descoberta em Pompéia cuja origem remonta ao século III d.C., por exemplo, é composto 
de apenas cinco palavras, que podem ser lidas tanto na vertical quanto na horizontal, e ainda da esquerda para a direita e da direita para a esquerda:

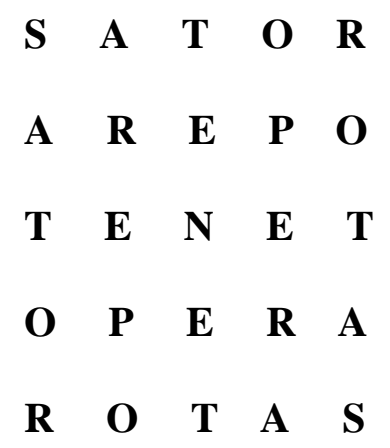

Este labirinto, diz Ana Hatherly, permite a criação de “treze frases anagramáticas” e ainda da frase latina Pater Noster, por meio de uma leitura feita conforme a técnica do “salto de cavalo” (idem, 99). É possível obtermos também o monograma de Cristo, AO, que indica o Alfa e o Ômega, o Início e o Fim. O sentido geral desse poema enigmático, segundo Gustav R. Hocke, citado por Ana Hatherly, seria o seguinte: “Deus (Sator) domina (tenet) a criação (rotas) e as obras dos homens (opera)” (idem), mas é possível haver outras camadas de leitura a partir da recombinação das letras, conforme o princípio do anagrama (a palavra rotas, por exemplo, se transforma em tarots).

Ana Hatherly define o anagrama como a "comutação das letras duma palavra (ou palavras) duma frase de modo a, por novo(s) arranjo(s), se formar(em) outra(s) diferente(s) da(s) primeira(s), sem que seja portanto necessário respeitar a ordem da sua colocação original” (idem, 185). Um exemplo de anagrama citado pela autora é a frase latina AVE MARIA GRATIA PLENA DOMINUS TECUM, que se transforma em outra: VIRGO SERENA PIA MUNDA ET IMMACULATA. A técnica do anagrama foi utilizada em diversas obras literárias do barroco, como o Jardim anagramático de divinas flores lusitanas, hespanholas e latinas, de Alonso de Alcalá y Herrera, que contém 686 anagramas em prosa e verso, em 
geral de caráter laudatório. Composições como o Anagrama aritmético (Figura 3) ou o Anagrama ortográfico (Figura 4), de autoria desconhecida, chamam a atenção pelo modo como as palavras, letras, números e figuras geométricas são ordenados:

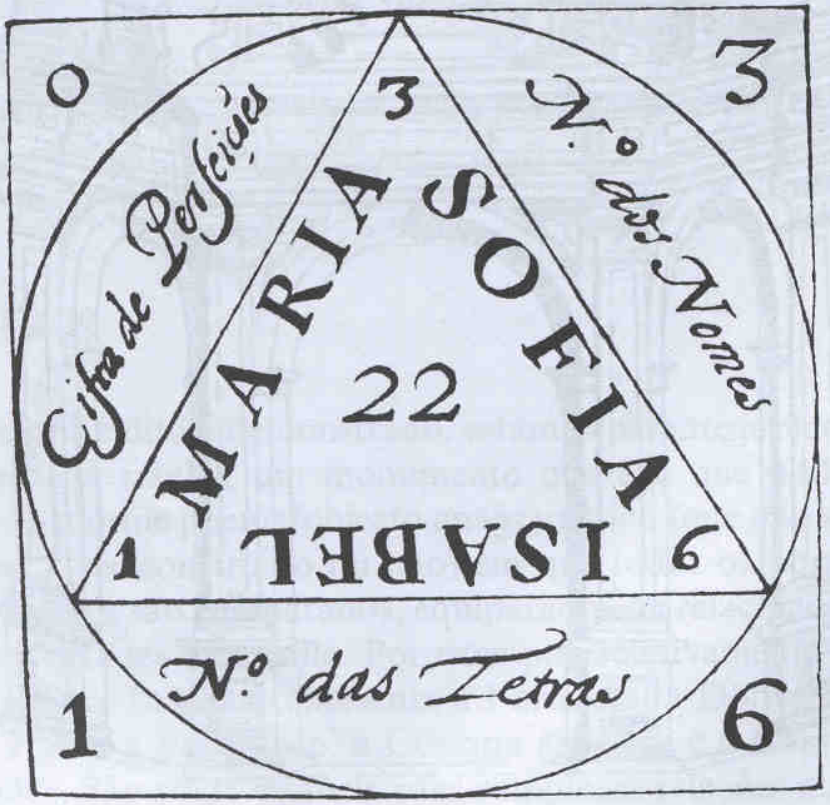

Fig. 12

Figura 3

No Anagrama aritmético, temos um triangulo dentro de um círculo dentro de um quadrado, com as palavras dispostas em sentido horizontal, na diagonal e de cabeça para baixo, com os números inseridos nas laterais e no centro da composição, onde lemos o nome da rainha Maria Sofia Isabel. Segundo Ana Hatherly, a chave para a compreensão deste poema foi dada pelo próprio autor, que assim decifra a sua simbologia numérica:

Os Nomes de Maria Sofia Isabel têm 16 letras e são constituídos por três unidades. O número três significa a apreensão da Divina Sabedoria e a redenção da Alma à Divina Vontade. O número 6 denota perfeição e bondade. O número 10 é a idéia de Perfeição. Têm mais os 3 nomes que em cada um dos primeiros há o número 5 e no terceiro 6 . O número 5 significa Bondade e o 6 perfeição da Bondade. (HATHERLY, 1995a: 32) 


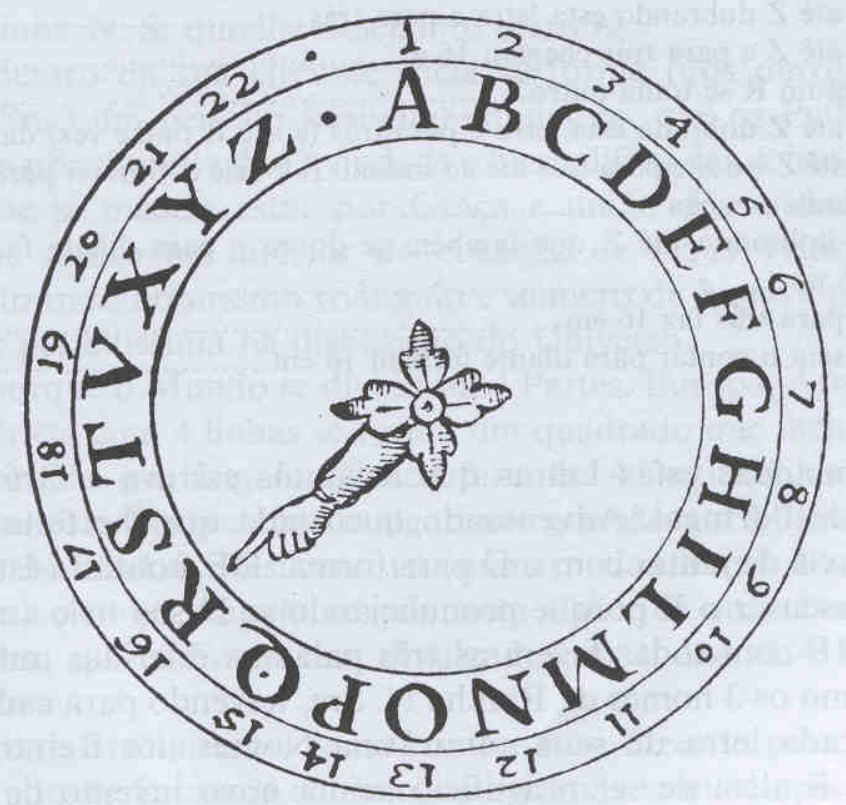

Fig. 13

33

\section{Figura 4}

No Anagrama ortográfico, temos três círculos concêntricos, o primeiro com uma seqüência numérica, o segundo com uma seqüência alfabética e o terceiro com um ícone no centro à maneira de um mostrador de relógio, em forma de braço humano. Em ambas as peças, a leitura é complexa, exigindo um esforço de decodificação a partir das relações entre letras e números, que fazem surgir diferentes níveis de significados. Comentando o Anagrama ortográfico, escreve Horácio Costa, em ensaio publicado no livro Mar abierto:

Tiene la forma de un disco, en el que las veintidós letras del antiguo alfabeto português están dispuestas en orden numérico, con el número correspondiente escrito en el margen; el centro del disco está ocupado por una especie de mano que nos recuerda um collage de Max Ernst y que apunta la letra 'R', número 16, indicando así el punto de início para la 'lectura' del objeto. El programa para su desciframiento es demasiado largo para ser referido aquí; se trata de una mezcla de informaciones numerológicas, ocultas y inspiradas en la doctrina cristiana, unidas con una imaginación irrestricta y uma combinatoria caprichosa para obtener las palabras RAINHA DE PORTUGAL. (COSTA, 1998: 57-58) 
Uma modalidade específica do labirinto de letras é o chamado labirinto cúbico, “em que as letras estão de tal modo escalonadas que, começando pelas do primeiro verso, por todos os lados se hão-de encontrar na mesma ordem” (HATHERLY, 1995a: 50).

Como exemplo dessa técnica, em que o poema tem o mesmo sentido se for lido da esquerda para a direita ou da direita para a esquerda, de cima para baixo ou de baixo para cima, Horácio Costa cita um labirinto cúbico de autor desconhecido, composto de uma única sentença escrita em latim, In utroque César, ou "César en dos (o en ambas) direcciones", ou ainda "César (el césar, el emperador) en los dos lugares (Portugal y Brasil)”. Esse poema foi escrito em homenagem ao vice-rei Vasco César de Meneses e constitui "una espécie de panegírico muy condensado y metalingüístico, que puede ser leído al menos de dos maneras, vertical y horizontalmente” (COSTA, 1998: 56-57) ${ }^{16}$.

Ana Hatherly, por sua vez, cita o poema Entrai José triunfante, em que "o verso inicial (e único) é repetido com sucessivos defasamentos, como se fosse escrito em espiral, por exemplo sobre um cilindro que rodasse" (HATHERLY, 1995a: 50). O "princípio da transformação cinética do labirinto”, diz a autora, “ilustra, mais uma vez, a importância do jogo óptico, fulcral para a compreensão da arte do maneirismo-barroco” (idem).

Todos esses recursos de comunicação poética, integrados à estrutura visual do poema, constituem uma "representação emblemática ${ }^{17}$ " ou "expressão hieroglífica da

\footnotetext{
${ }^{16}$ Os labirintos poéticos portugueses, com efeito, em geral são poemas de louvor à Virgem Maria, aos santos ou a membros da realeza e da aristocracia, o que motivou críticas a sua suposta frivolidade. A esse respeito, Ana Hatherly diz, em A casa das musas: "Mas dum estudo atento às causas possíveis de tal aparência, que efetivamente pode apresentar, se tivermos em consideração que o tempo do seu surgimento corresponde a uma época não só de instabilidade mas também de repressão religiosa e política, concluiremos, talvez, que o que era 'permitido' aos poetas cultos exprimir cabia praticamente só dentro do panegírico ou dos jogos da corte." (idem, 26-27) Mais adiante, a autora diz ainda: "O que resta então aos artistas fazer nessa sociedade repressiva e convencional até o delírio, que propõe como únicas saídas o pietismo ou a mitologia? O mesmo que em todas as épocas eles mais ou menos sempre fizeram: subverter pela invenção”. (idem, 46)

${ }^{17}$ Conforme Walter Benjamin, citado por Ana Hatherly, “onde quer que reine o espírito do barroco está-se no domínio da representação emblemática” (HATHERLY, 1983: 70).
} 
multiplicidade de significado do texto, que reflete a multiplicidade do significado do mundo” (HATHERLY, 1980: 70), diz Ana Hatherly. Segundo a autora portuguesa, “a multiplicidade e a mobilidade de imagens são o fundamento dinâmico da concepção da arte barroca em que impera, soberana, a alegoria” (idem). A palavra alegoria, aqui, não indica apenas a simbolização concreta de conceitos abstratos, mas a “duplicação de significado, leitura em correspondência: texto sob o texto. Assim, toda alegoria é um anagrama sui generis, uma forma de desdobramento do significado, e logo uma forma de enriquecimento da leitura” (idem, 71) ${ }^{18}$. Em resumo: combinação, permutação, ambigüidade, mobilidade e pluralidade de leituras são as palavras-chave para a compreensão dos labirintos, regidos pelo “culto da engenhosidade, do artifício e do espetáculo, entendidos como jogo ou desafio intelectual” (HATHERLY, 1995a: 155), que exigem a participação fruitiva do leitor, cúmplice do poeta.

\section{2 - A obra labiríntica na modernidade}

Affonso Ávila observou que o labirinto poético pode ser considerado uma forma de “estrutura aberta”, de acordo com o conceito de Umberto Eco, por ser um tipo de texto “suscetível de várias direções de leitura, isto graças ao artifício do ordenamento de versos e estrofes, da equivalência de sentido das frases e a sua permutável correspondência na organização gráfica do poema” (ÁVILA, 1994: 122). As leituras possíveis do labirinto, prossegue, "se multiplicam, tanto ao nível dos blocos, quanto das estrofes e dos versos,

\footnotetext{
${ }^{18}$ Conforme escreveu Walter Benjamin em seu livro sobre o drama barroco alemão: "Nos anagramas, nas expressões onomatopaicas e em muitos outros artifícios de linguagem, a palavra, a sílaba e o som, emancipados das correntes articulações de sentido, desfilam como coisas à espera de serem alegoricamente exploradas. A linguagem do barroco está constantemente a ser abalada pelas rebeliões dos seus elementos”. (BENJAMIN, 2004: 228)
} 
podendo estes concatenar-se de modo compreensível, seja em linha horizontal ou vertical, seja mesmo em diagonal, obedecendo-se qualquer ordem de leitura dos versos” (idem). A pluralidade de leituras obtida no labirinto poético, com efeito, aproxima-se do conceito de obra aberta, em que há um “feixe de possibilidades móveis e intercambiáveis” (ECO, 1976: 12), no dizer de Giovanni Cutolo, governado “pelas leis de probabilidade” (idem, 10). A estrutura da obra aberta "torna-se esteticamente válida na medida em que pode ser vista e compreendida segundo multíplices perspectivas”, diz Umberto Eco, “manifestando riqueza de aspectos e ressonâncias sem jamais deixar de ser ela própria” (idem, 40).

A mobilidade estrutural e a proliferação de rotas interpretativas podem ser encontradas em obras da modernidade como o Livro $^{19}$ inacabado de Mallarmé, poema labiríntico que, segundo Haroldo de Campos, “incorpora a permutação e o movimento como agentes estruturais” (CAMPOS, 1976: 18), superando a categoria de “obra circular”, que pressupõe certa linearidade espaço-temporal, definida já em sua estrutura material: o livro, com uma organização seqüencial do tipo início-meio-fim. O poeta francês, seguindo direção oposta à da lógica narrativa clássica, concebeu, segundo Haroldo de Campos, um “multilivro onde, a partir de um número relativamente pequeno de possibilidades de base, se chegaria a milhares de combinações” (idem).

As páginas desse poema inconcluso, afirma Umberto Eco, “não deveriam obedecer a uma ordem fixa”, mas seriam “agrupáveis em ordens diversas” numa "série de fascículos independentes (não reunidos por uma paginação que determinasse a sua seqüência” (ECO, 1976: 52). As folhas seriam "soltas, simples, móveis, intercambiáveis, mas de tal maneira que, fosse qual fosse a ordem de sua colocação, o discurso possuísse um sentido completo”

${ }^{19}$ Os esboços do Livro, de Mallarmé, descobertos postumamente, foram publicados pela primeira vez em 1957 por Jacques Scherer. No Brasil, apenas alguns fragmentos foram traduzidos por José Lino Grunewald, no livro Poemas de Mallarmé (Rio de Janeiro: Nova Fronteira, 1990). 
(idem, 53). A “estrutura dinâmica desse objeto artístico”, segundo o autor italiano, "pretende realizar um ditame de poética bem definido: un livre ni commence ni ne finit; tout au plus fait-il semblant” (idem, 52). O caráter mutável, poliédrico do Livro, ao permitir a incessante criação e transformação de mensagens, afasta-se de uma concepção tradicional de sentido, que não é abolido, mas elevado ao infinito (ou, no mínimo, ao indeterminado). Segundo Eco, no multilivro mallarmaico não se deveria encontrar "nenhum sentido fixo, assim como não era prevista uma forma definitiva: se uma só passagem do livro tivesse um sentido definido, unívoco, inacessível às influências do contexto permutável, tal passagem teria bloqueado o mecanismo todo” (idem, 53-54). A informação, na obra de arte aberta, torna-se exponencial: “quanto mais a estrutura se torna improvável, ambígua, imprevisível e desordenada, tanto mais aumenta a informação. Informação entendida, portanto, como possibilidade informativa, incoatividade de ordens possíveis” (idem, 162).

O Livro de Mallarmé, com a sua “arquitetura permutatória e tridimensional da escrita” (PINHEIRO, 1993: 167), antecipa, de certo modo, experiências interativas que se tornaram possíveis com as novas tecnologias eletrônicas, e em especial com a informática e a navegação na internet. Segundo Amálio Pinheiro,

O sonho de Mallarmé, perseguido durante toda a sua vida, era dar forma a um livro integral, um livro múltiplo que já contivesse potencialmente todos os livros possíveis; ou talvez uma máquina poética, que fizesse proliferar poemas inumeráveis; ou ainda um gerador de textos, impulsionado por um movimento próprio, no qual palavras e frases pudessem emergir, aglutinar-se, combinar-se em arranjos precisos, para depois desfazerse, atomizar-se em busca de novas combinações. (...) Trata-se verdadeiramente de um livro-limite, 'o limite da própria idéia ocidental de livro', como diz Haroldo de Campos (1969: 19), que desafia os nossos modelos habituais de escritura e aponta para o livro do futuro (...) que, segundo Blanchot (1959: 335), já não está verdadeiramente em lugar algum, nem se pode mais ter nas mãos. (PINHEIRO, 1993: 165-66)

A experiência realizada por Mallarmé em sua estética do inacabado e do permutável encontra paralelos em obras da vanguarda como o Finnegans Wake de James Joyce, onde 
“todo acontecimento, toda palavra, encontra-se em numa relação possível com todos os outros e é da escolha semântica efetuada em presença de um termo que depende o modo de entender todos os demais” (ECO, 1976: 48). O principal recurso utilizado nessa escritura de ambigüidade radical, na opinião do pensador italiano, é o pun ou calembour: “onde duas, três, dez raízes diferentes se combinam de forma que uma única palavra se torne um nó de significados, cada qual podendo encontrar-se e correlacionar-se com outros centros de alusão abertos ainda a novas constelações e probabilidades de leitura” (idem, 49).

No campo da criação musical, é possível estabelecermos paralelos entre o princípio permutatório de Joyce e Mallarmé e obras como a Klavierstuck XI, de Karlheinz Stockhausen, a Sequenza per flauto solo, de Luciano Berio, ou a Troisième sonate para piano de Pierre Boulez, que incorporam a mobilidade, a permutação e a participação inventiva do músico, que tem a possibilidade de escolher a seqüência em que serão executados os movimentos de cada composição, e mesmo de intervir "na forma da composição, estabelecendo a duração das notas ou a sucessão dos sons, num ato de improvisação criadora” (idem, 37).

Em tais composições, não existe a idéia de conclusão, de permanência, mas de contínua metamorfose, numa “nova dialética entre obra e intérprete” (idem, 39). Em vez de uma "forma univocamente organizada”, temos uma "possibilidade de várias organizações confiadas à iniciativa do intérprete” (idem). Portanto, “cada fruição é, assim, uma interpretação e uma execução, pois em cada fruição a obra revive dentro de uma perspectiva original” (idem, 40).

A pluralidade de vias interpretativas, no entanto, não significa primazia do aleatório; a “inteligência criadora” não é vencida pelo “puro automatismo e ao caos” (CAMPOS, 1976: 20). No percurso do labirinto multicursivo, como na leitura/execução de uma obra aberta, 
os “resultados fruitivos” são "rigidamente prefixados e condicionados, de maneira que a reação interpretativa do leitor não escape jamais do controle do autor” (ECO, 1976: 43), numa dialética entre acaso e logos. Na Sonata de Pierre Boulez, por exemplo, há cinco movimentos, ou formantes: Antífona, Tropo, Constelação, Estrofe e Seqüência. A ordem destas seções nunca é a mesma em cada execução, mas o compositor declara obrigatória “a colocação do mais longo e mais importante dos cinco formantes, a Constelação, que deve ficar sempre no centro do edifício” (CAMPOS, 1976: 20). De modo similar, em sua Klavierstucke XI, Stockhausen apresenta 19 grupos sonoros que “que são distribuídos e devem ser lidos pelo intérprete segundo indicações que lhe deixam uma grande margem de liberdade na articulação geral do conjunto” (idem, 20-21). Já na Sequenza per flauto solo, de Berio,

o intérprete acha-se diante de uma partitura que lhe propõe uma textura musical onde são dadas a sucessão dos sons e sua intensidade, enquanto que a duração de cada nota depende do valor que o executante deseje conferir-lhe no contexto das constantes quantidades de espaço correspondentes a constantes pulsações de metrônomo. (ECO, 1976: 38)

Outra seria a atitude de rebeldia estética do compositor norte-americano John Cage, voltado "programaticamente ao caos e à pura franquia do acaso” (CAMPOS, 1976: 21), cujo método "se baseia na manipulação aleatória do jogo chinês de palitos da sorte, o I-CHING, com 64 possibilidades de permutação” (idem). A incorporação do acaso como um fator determinante na obra de arte, tal como efetuado por Cage, é considerada pelo autor brasileiro uma espécie de "transposição, para a música, do tachismo, ou, mais exatamente, da action paiting, cultivando-se o indeterminismo no seu grau mais elevado” (idem).

Essa transformação contínua da obra, que a cada execução é diferente, recorda outro conceito de Umberto Eco, a de obra em movimento, que não se limita à arte musical, 
tendo desdobramentos, inclusive, nas artes visuais, sobretudo nas esculturas móveis, ou móbiles, de Alexander Calder, que nas palavras de Eco são “estruturas elementares que possuem justamente a capacidade de mover-se no ar, assumindo disposições espaciais diversas, criando continuamente seu próprio espaço e suas próprias dimensões” (ECO, 1976: 51$)^{20}$

O conceito de obra em movimento poderia ser aplicado também a algumas peças da artista plástica brasileira Lygia Clark, e em especial a série de esculturas em metal designada Bichos, que podem ser manipuladas pelos espectadores, assumindo diferentes contornos visuais; Mary Vieira, com a sua scultura mobile, e Waldermar Cordeiro, com a obra Aleatório, também são considerados artistas representativos desse campo de pesquisa estética por Haroldo de Campos, que no livro A arte no horizonte do provável afirma: “a programação do acaso, sua integração na estrutura da obra, constitui hoje uma das preocupações dominantes da vanguarda internacional” (CAMPOS, 1977: 25-26).

O autor brasileiro cita, em defesa de sua afirmação, um adágio de Umberto Eco, para quem existe “uma dialética singular entre acaso e programa, entre matemática e aleatório, entre concepção planificada e aceitação livre daquilo que sucederá segundo precisas linhas (...) que não negam a espontaneidade, mas que lhe põem limites e direções possíveis” (idem, 26). Essa dialética é a pedra-de-toque de algumas das experiências mais radicais da vanguarda da segunda metade do século XX e início do XXI, e é nesse contexto que estudaremos agora o romance visual $O$ escritor, de Ana Hatherly.

${ }^{20}$ O conceito de obra em movimento, diga-se de passagem, não era desconhecido dos poetas experimentais portugueses; António Aragão refere-se a ele no artigo Intervenção e movimento, onde afirma: "Trata-se, sem dúvida, de obras em movimento onde cada fruição jamais resulta igual a si mesma (Umberto Eco), nesse mesmo sentido de campo de possibilidades a que se refere Henri Pousseur. Por isso o estilo da obra de arte, tal como se entende à maneira convencional, desapareceu. $\mathrm{O}$ artista apenas oferece uma estrutura, expõe uma base, uma matriz, e deixa o resto ao acaso das intervenções” (HATHERLY, Ana, e MELO E CASTRO, E. M.: 1981, 54-55). 


\section{3 - O escritor: uma “máquina de produzir desordem”}

Lima de Freitas, no ensaio Das geometrias labirínticas, cita os "labirintos de via múltipla destituídos de centro” (FREITAS, 1985: 71), em que a “arbitrariedade combinatória de todos os sentidos” equivale “à desaparição do sentido” (idem, 74): o peregrino descobre que o centro está em toda parte, "nem fora nem dentro, porque deixam de existir, a partir dessa consciência, o ‘dentro’ e o ‘fora’ irredutíveis da lógica corrente” (idem).

No livro Sobre os espelhos, Umberto Eco define essa construção como uma “rede na qual cada ponto pode ter conexão com qualquer outro ponto” (ECO, 1989: 338). Conforme o autor italiano, esse tipo de labirinto "pode ser finito ou (contanto que tenha possibilidade de expandir-se) infinito. Em ambos os casos, dado que cada um dos seus pontos pode ser ligado a qualquer outro ponto (...), seria sempre ilimitado” (idem, 339). Isto ocorreria porque “a sua estrutura seria sempre diferente da que era um momento antes e a cada vez se poderia percorrê-lo segundo linhas diferentes” (idem).

Nesta “máquina de produzir desordem”, escreve Lima de Freitas, confluem o aspecto racional da geometria, ou seja, "estruturas ordenadoras evidentes para a consciência clara e pensante, manifestadas aos nossos olhos como forma, ordem espacial, número, matriz, invariante”, mas também um “abismo de caos” e “acelerador de incoerência”, ressaltando o caráter de jogo da construção labiríntica (FREITAS, 1985: 71).

A arquitetura excêntrica dessa modalidade de labirinto favorece um paralelo com $O$ escritor, de Ana Hatherly, livro sem palavras formado por linhas, formas gráficas, cores, letras, números, dispostos numa ordem geométrica caótica no espaço em branco da página, contrariando hábitos rotineiros de leitura. Dizer que este livro é um “romance” é um gesto transgressivo da autora, uma vez que a obra escapa a qualquer definição de texto literário, questionando inclusive o conceito de literatura, já que o seu “texto” é puramente visual. 
A impossibilidade de leitura linear desse livro estranho convida a inteligência do leitor a perder-se em seus intermináveis trajetos possíveis, numa aventura entre o risco e o cálculo planejada pela autora, que busca uma relação de cumplicidade criativa com o leitor:

O problema da leitura, já todos sabemos, é um problema de decodificação, um problema de interpretação a que se acrescenta, no caso da área artística, a necessidade duma certa co-participação na criatividade, pois os elementos dados, para serem realmente entendidos, para serem integralmente fruídos, precisam ser recriados de cada vez que o texto entre em contato com o seu leitor (HATHERLY, 1979: 108)

É evidente que neste labirinto destituído de centro, que não oferece as regras de um programa para facilitar a decifração (ao contrário de Leonorana), toda tentativa de leitura é uma temeridade, ou, mais exatamente, uma das quase infinitas possibilidades de construção do sentido; acrescentar mais uma é apenas cumprir o desígnio da própria obra, que rejeita certezas estáveis: seu território é o da instabilidade criadora, e nisso reside o seu encanto.

O título do livro apresenta uma indisfarçada ironia, ao identificar com a palavra “escritor” um conjunto de imagens que não é, exatamente, o tipo de produção que se espera de alguém que pratica a literatura, ou seja, texto verbal. Seria um paradoxo ou provocação, se esquecêssemos o conceito de texto visual, que Ana Hatherly foi buscar em Max Bense para definir a poesia figurativa do barroco português, no livro A experiência do prodígio. Conforme Affonso Ávila, “a poesia seiscentista, como a de hoje, foi tentada a exprimir-se em formas híbridas, procurando dizer visualmente algo mais do que podia o simples verso tradicional” (ÁVILA, 1994: 29). Para isso, recorreu “ao auxílio da pintura, da gravura, em composições que se aproximam do caligrama e de outras montagens modernas” (idem).

A composição híbrida, que recusa ser um artefato meramente literário, segundo Ávila, equivale a uma “poesia não-verbal, construída a partir de signos visuais, de formas aleatórias ou geométricas” (idem, 35-36), que nasce de uma “nova noção de estrutura da 
obra literária, da poesia, em decorrência da qual pode o escritor lograr uma linguagem mais inventiva” (idem, 29). Seguindo o raciocínio traçado por Ávila, podemos considerar $O$ escritor um artefato estético que desconsidera as distinções entre literatura e artes visuais, bem como entre ficção, poesia e qualquer outro gênero delimitável, trazendo "uma dimensão nova, inesperada, aos nossos métodos de leitura” e uma “alteração nos hábitos culturais” que ainda está “longe de ser assimilada”21 (HATHERLY, 1979: 110). Composta entre 1967 e 1972, essa obra inusitada é um work in progress cujos “diferentes graus de legibilidade se tornam um desafio à construção de significados” (HATHERLY, 1975: 6). Ao publicar a obra, em 1975, a autora, de maneira paradoxal, finaliza e propõe o recomeço do trajeto nesse labirinto de imagens. Nas palavras de Ana Hatherly, “o autor concebe o percurso da experiência e realiza-o primeiro mas ao publicá-lo deturpa-o, isto é, transfigura-o, e desse modo a sua experiência o ultrapassa” (idem, 5), agora que o livro fica à mercê da “interpretação que dela hão-de fazer os leitores” (idem).

É assim, prossegue a autora, que “o leitor torna-se uma testemunha que depõe, agindo nesse processo histórico” (idem, 6). Em lugar da passividade inerente às narrativas tradicionais, em que o leitor é conduzido pelo autor até um desfecho coerente com a construção ficcional, neste anti-romance de imagens que constitui “uma estrutura viva, em constante processo de transformação” (HATHERLY, 1979: 109), temos a participação imaginativa do leitor ${ }^{22}$ numa subversão da ordem convencional de leitura, inclusive da obra

\footnotetext{
21 Ana Hatherly afirma que O escritor “não é verdadeiramente um poema, um conjunto de poemas ou propriamente uma obra literária, no sentido tradicional do termo: na minha opinião, trata-se do que poderíamos chamar simplesmente um texto-não-texto”. (HATHERLY, 1979: 107)

${ }^{22}$ Maria João Fernandes, comentando o livro A reinvenção da leitura (1975), de Ana Hatherly, fala na "leitura como criação e a criação como interpretação, decodificação do texto que se oculta sob o texto" (HATHERLY, 2004: 79). Fernandes diz, no mesmo ensaio, que "Os problemas mais gerais da comunicabilidade do texto levam, segundo a autora, à prática do texto-imagem 'que simultaneamente transcende e engloba o problema do conteúdo ao nível do significado’, alargando este para o que se poderia
} 
aberta regida por regras específicas. Esta subversão artística representa outra, no campo social (recordemos que $O$ escritor foi gestado na fase final da ditadura salazarista): trata-se da quebra de hierarquias, funções e normas, numa consciente e deliberada anarquia criativa. No parágrafo final da nota introdutória, Ana Hatherly registra o "desânimo”, a “descrença”, a "revolta” e a "repulsa” de sua geração ao sistema vigente; O escritor seria, nesse contexto, "uma representação necessária dum estado de repressão prolongada" (HATHERLY, 1975: 6) e um convite à resistência pela capacidade radical de invenção.

O escritor, segundo Ana Hatherly, é uma "narrativa em 27 fases”, em que o sentido de cada fase "é posto em movimento pela leitura”, que será "sempre múltipla porque à ilusão de ver se acrescenta a ilusão de ler” (HATHERLy, 1975: 5). A palavra ilusão, derivada do latim illusione, significa, conforme o Novo Dicionário Aurélio da Língua Portuguesa, "engano dos sentidos ou da mente, que faz que se tome uma coisa por outra, que se interprete erroneamente um fato ou uma sensação" (HOLLANDA, 1986: 917).

Ao fazer da ilusão um elemento intrínseco à operação de leitura dessa obra inquietante, Ana Hatherly renuncia à delimitação de sentidos precisos e incorpora o ruído ${ }^{23}$, o desvio da rota, o caos e a dispersão como meios criativos para a construção de significados (assumindo, portanto, todos os riscos apontados por Umberto Eco em Os limites da interpretação). As imagens dessa narrativa são compostas de letras, sílabas,

designar por um 'campo de significação integral' e representam uma tentativa de alargar o campo da leitura e o campo da escrita, restituindo-lhes a sua 'força original, semiótica, icônica, autonomamente semântica' ” (idem).

${ }^{23}$ Abraham Moles, no livro Teoria da informação e percepção estética, considera que a diferença entre sinal e ruído é arbitrária e que, em algumas situações, o ruído, "fenômeno anárquico da natureza, desprovido de sentido" é na verdade "uma mensagem particular" que não é entendida porque "o receptor não está a par das intenções do transmissor" (MOLES, 1969: 96). Nesses casos, a ausência de significação imediata não quer dizer carência de informação; ao contrário, haveria aqui uma quantidade maior de informação, já que esta, para Moles, é derivada “da originalidade, e não da significação” (idem, 41). 
sinais de pontuação ou números associados a figuras semelhantes a traços caligráficos; nenhuma palavra consta nesses quadros, a não ser aglutinações semânticas como KPYOTL, MNAA ou MORLU?, que lembram a linguagem zaúm ${ }^{24}$, ou transmental, do poeta russo Velimir Khlébnikov, ou as experiências sonoras abstratas de Antonin Artaud ("Talachtis talachtis tsapoula / koiman koima Nara”) ${ }^{25}$. Em algumas fases do livro, as formações léxicas assemelham-se a pequenos poemas que desafiam qualquer possibilidade de pronúncia, pela ausência de vogais; é como se a autora representasse a destruição da língua, retornando ao tema da incomunicabilidade, presente em obras como as Tisanas e O mestre; porém, enquanto nesses títulos a dificuldade de entendimento é urdida pelo recurso ao absurdo, ao non sense, aqui a própria referencialidade é abolida na pura música visual e o alfabeto, reduzido a signos plásticos.

Essa tendência é marcante nas dez primeiras fases do livro, nas quais a dificuldade de interpretação é ampliada pela disposição de letras e figuras em páginas duplas, como no Lance de dados, de Mallarmé: a leitura dos signos pode ocorrer na horizontal (de uma a outra página), na vertical, na diagonal, em espiral, como nos trajetos do labirinto poético. Na fase 8, todas as letras são arranjadas num único bloco, inclinadas à esquerda, à direita, invertidas ou sobrepostas, com borrões de tinta que sugerem a desintegração do alfabeto em puro ruído ou caos caligráfico (Figura 5). Essa fase prenuncia o segundo andamento do

\footnotetext{
${ }^{24}$ Marjorie Perloff define o zaúm como "linguagem que corrói ou ignora os significados convencionais de uma determinada palavra, permitindo assim que o seu som gere o seu próprio círculo de significações, ou, em sua forma mais extrema, a invenção de novas palavras baseadas puramente no som” (PERLOFF, 1993: 214).

${ }^{25}$ É possível fazermos um paralelo entre os procedimentos estéticos utilizados por Ana Hatherly em $O$ escritor e as experiências do futurismo italiano. Comentando os manifestos de Marinetti, a ensaísta norteamericana Marjorie Perloff fala numa "tipografia inovadora, expressiva - o uso de diferentes cores de tinta e de diferentes tipologias, espaçamentos e tamanhos de letras e de palavras - assim como um elaborado sistema de artifícios onomatopaicos, substituirão o ‘código cifrado abstrato' da sintaxe” (PERLOFF, 1993: 118). Recursos similares vamos encontrar nos livros visuais do cubo-futurismo russo e nos manifestos dadaístas de Tristan Tzara, todos antecedidos pelo Lance de dados de Mallarmé. O que diferencia o "textonão-texto" da autora portuguesa, talvez, seja o seu caráter narrativo de sequência de imagens, ainda que sem óbvia referencialidade, e uma aplicação muito particular do uso das cores e imagens como forma de escrita.
} 


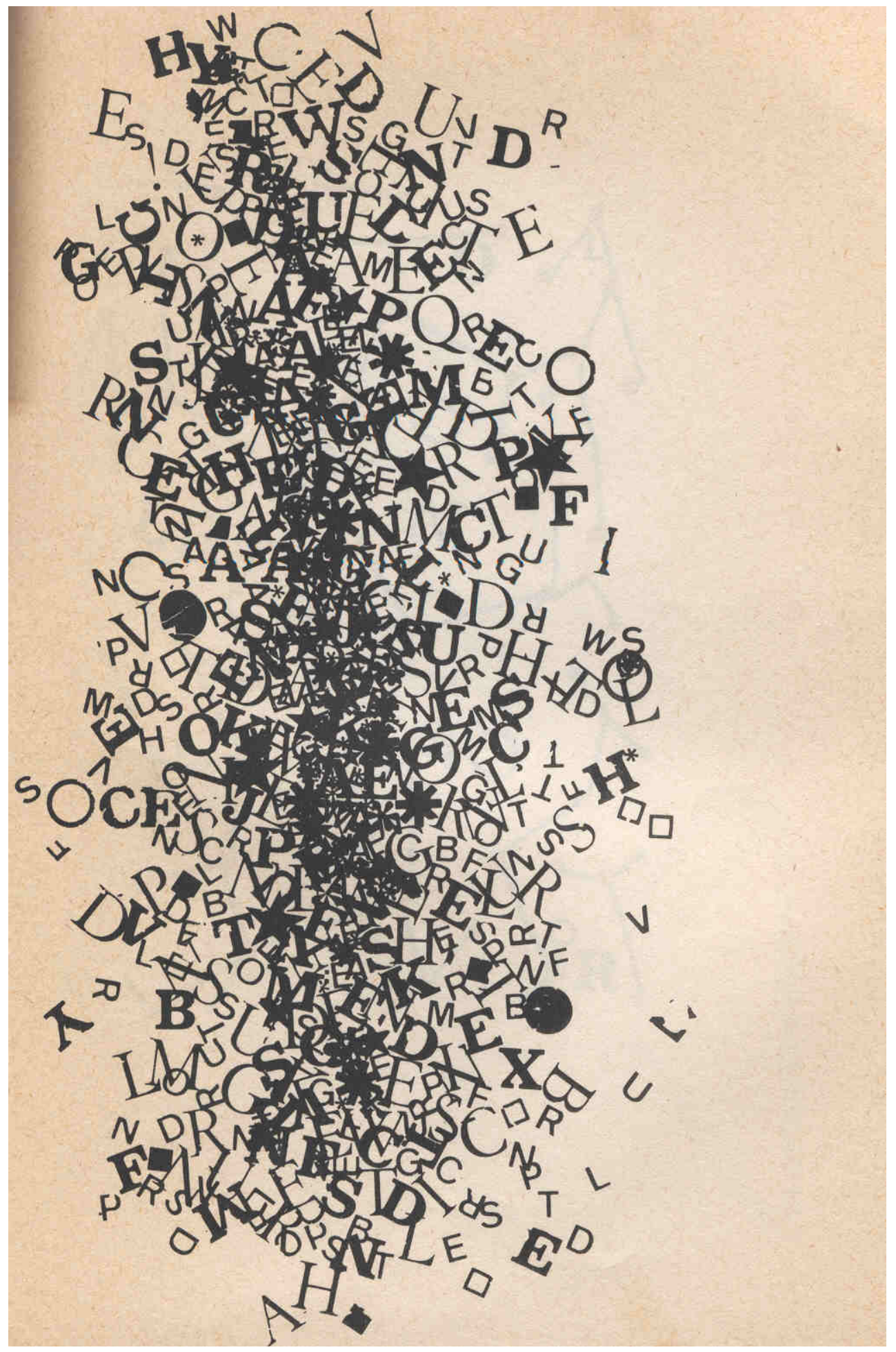

Figura 5 
livro, em que o grafismo se sobrepõe ao traçado das letras, assumindo a completa abstração, com o acréscimo de cores e a justaposição de figuras como círculos, quadrados, linhas, curvas e outros elementos, inclusive ícones como a mão que segura uma caneta (fase 12), setas (fase 17) e ondas paralelas simulando o perfil de um rosto, com poucas inserções de letras e números, que são colocados em legendas dispostas abaixo das imagens, como nos emblemas barrocos (fases 13, 15 e 16).

O rosto caligráfico que surge na fase 13 assume diferentes variações de traçado, num crescendo: na fase 17, ele é uma figura puramente geométrica, em branco e preto, composta de linhas ondulantes e formas triangulares, com saliências que sugerem o nariz e a boca; nas fases 18 e 19, o rosto é borrado, e o desenho se torna mais enigmático, numa sucessão de curvas; na fase 20, adquire um perfil próximo à caricatura, e o traçado do contorno começa a sugerir um texto; nas fases 21 a 23, esse texto embrionário está dentro e fora dos limites do rosto, que é indistinto da própria escritura, como nos desenhos caligráficos árabes; na fase 24 (Figura 6), o rosto é representado pelo perfil de uma sombra de cuja boca sai uma profusão de letras, em explosão anárquica; por fim, na fase 27, as letras ressurgem alinhadas, em sequência alfabética, na coluna à esquerda da página, ao lado de outra, que reproduz um borrado texto caligráfico ${ }^{26}$.

O alfabeto está no início e no término desse livro ilegível em que “o texto e a imagem comparecem num horizonte em que a contemplação e a leitura se confundem e são naturalmente geradoras de mistério ou pelo menos de enigmas”, segundo Jorge Molder (HATHERLY, 2000: 7). Uma possível interpretação dessa dinâmica de signos permite

\footnotetext{
${ }^{26}$ Segundo Ana Hatherly, a "lápide ou estela funerária dos modelos da cultura, expressos pelo alfabeto latino que surge corroído ao lado da escrita manual, ilegível já em parte e que se perde na impossibilidade da leitura tradicional” prefigura "o fim duma concepção da sociedade, da cultura e da história” (HATHERLY, 1979: 112).
} 


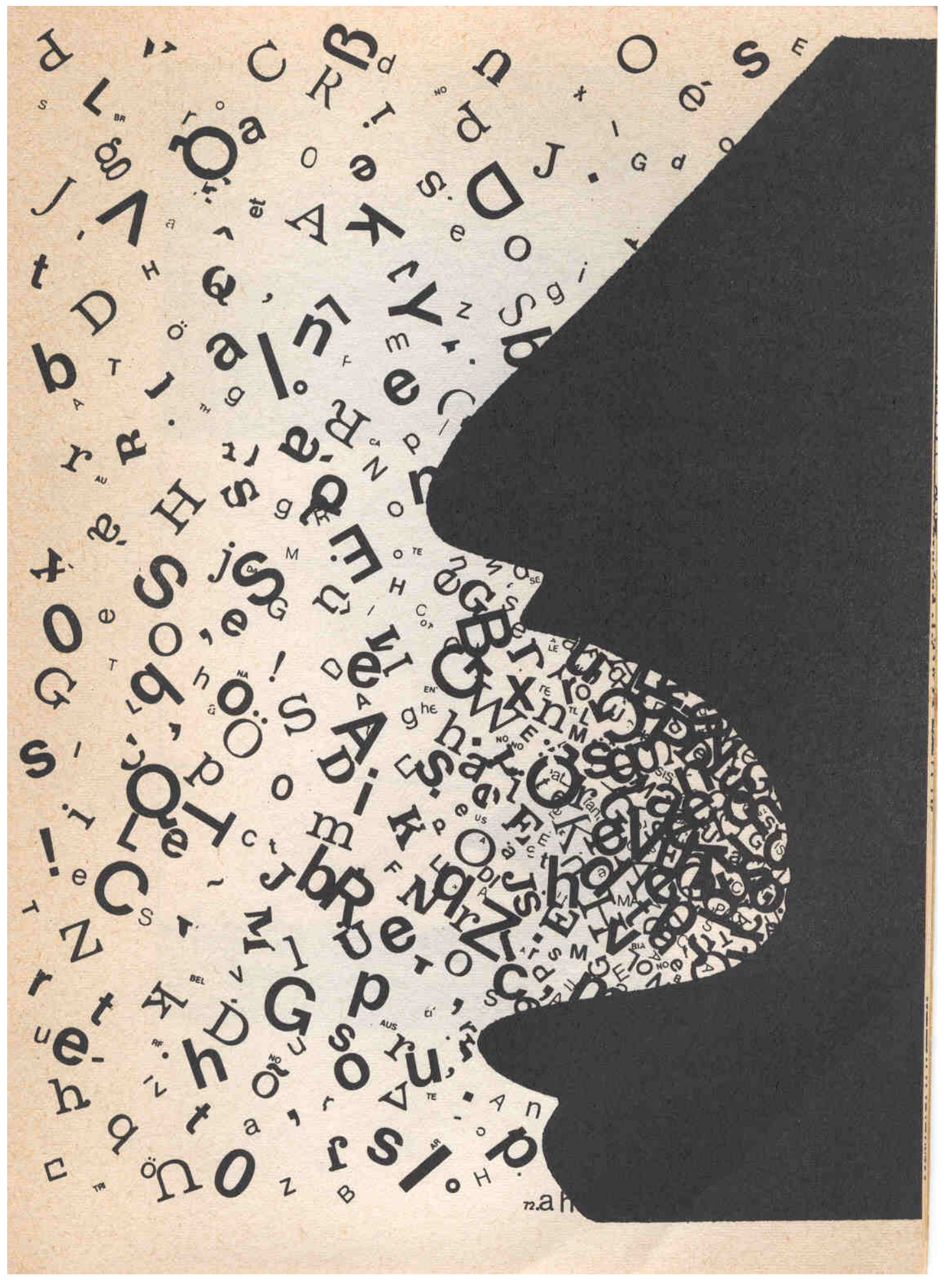

Figura 6 
sugerir os personagens de uma obra que se pretende um "romance”: são eles o enunciador e o enunciado, ou ainda a vida e a linguagem, numa complexa relação de aproximação e distanciamento, de construção e dissolução do sentido e do próprio sujeito, que se fragmenta em múltiplas faces que se contemplam, como na página dupla da fase 14 .

Temos portanto a alegoria de uma tensão entre significante e significado, entre indivíduo e história e consigo mesmo, numa complexa trama labiríntica assumida pela autora, quando afirma que "os problemas da escrita" refletem "os problemas do autor/vs. /sociedade”, bem como “a solidão do escritor” (que “chora lágrimas de tinta”), e ainda “o duelo autor/leitor, autor/sociedade, autor/texto, autor/autor” (HATHERLY, 1979: 111). Podemos fazer um paralelo entre essa angustiada pictografia e o ambiente psicológico do Maneirismo, onde, conforme Gustav Hocke, “o enigma da contradição se tornou algo obsessivo. O homem e o universo divorciaram-se. Os olhares se perdem no labirinto do insondável” (HOCKE, 2005: 25). Affonso Ávila fez observação similar, comparando a “tensão existencial” do homem barroco à do homem moderno, que seriam "um único e mesmo homem agônico, perplexo, dilemático", vivendo "agudamente e angustiosamente sob a órbita do medo, da insegurança, da instabilidade” (ÁVILA, 1994: 26). Nessa situação tensa, nada mais natural que o artista "também assuma formas agônicas, perplexas, dilemáticas” (idem).

Para o homem do século XVII, a insegurança era motivada pelas guerras, epidemias, pela Contra-Reforma e pela Inquisição; para o homem português da década de 1970, a insegurança era resultado de um sistema político autoritário, em que a censura, a perseguição política, a tortura e o assassinato de dissidentes eram rotinas não menos dolorosas que os autos-de-fé. O escritor que nomeia o livro de Ana Hatherly é talvez o “homem agônico” a que se refere Ávila, representado pela face enigmática que assume 
diferentes disfarces gráficos; é a própria autora, o leitor e o personagem do livro, num único e multifacetado signo.

Se adotarmos essa estratégia de decodificação do livro (tão hipotética e questionável quanto qualquer outra, nessa “máquina de produzir desordem”), a aparente incomunicabilidade do livro de Ana Hatherly não é uma negação ou ausência de sentido, mas um espelho que reflete em seus múltiplos estilhaços a perda de significados morais sob a égide da intolerância e da violência de uma ordem monolítica, e ao mesmo tempo a afirmação de outras ordens possíveis pelo processo de transgressão criativa.

\subsection{A reinvenção da escrita e da leitura}

Em seu trabalho como artista plástica, Ana Hatherly realizou de maneira mais radical a reinvenção da escrita e da leitura, que coloca em primeiro plano a materialidade visual dos signos. No texto de apresentação que escreveu para a exposição Desenho no Espaço, realizada em 1979 na Galeria Tempo, Ana Hatherly declarou que “O meu trabalho começa com a escrita — sou um escritor que deriva para as artes visuais através da experimentação com a palavra” (HATHERLY, 2000: 5). No mesmo texto, a autora afirma que "O meu trabalho também começa com a pintura — sou um pintor que deriva para a literatura através de um processo de conscientização dos laços que unem todas as artes” (idem) ${ }^{27}$.

Texto e imagem convergem na criação de signos que desafiam a normalidade da contemplação ou da leitura, multiplicando os graus de estranhamento. “A descoberta da escrita na imagem e a descoberta da imagem na escrita”, conforme Jorge Molder, está na essência do processo criativo de Ana Hatherly, e “constituem um movimento que

\footnotetext{
${ }^{27}$ As citações foram extraídas do prólogo escrito por Jorge Molder para o catálogo da exposição Hand made, que reúne trabalhos visuais de Ana Hatherly (Lisboa: Fundação Calouste Gulbenkian, 2000).
} 
encontramos forçosamente num primeiro momento, como surpresa e espanto primitivos” (idem). A presença da escrita na imagem, diz o crítico, pode ser rastreada já no barroco e na poesia chinesa, não por acaso pontos de partida para o movimento da $P O-E X$. A própria Ana Hatherly declara que "os meus desenhos-escritas inserem-se na longa tradição dos calígrafos orientais e dos barrocos europeus, remontando à tradição dos caligramas gregos alexandrinos, que eu reinvento” (idem, 9).

Em Mapas da imaginação e da memória, série de desenhos caligráficos realizados ao longo de dez anos e publicados parcialmente em 1973, a autora parte do estudo das escritas arcaicas chinesa, escandinava, latina e semítica, entre outras, para criar um “alfabeto estrutural”,28 baseado em oito caracteres, que se combinam de múltiplas formas, como os trigramas do I Ching. Segundo a autora, “não atribuí expressamente nenhum valor semântico a cada um desses elementos, ou a qualquer conjunto deles, porque quis apresentar uma proposta em aberto” (HATHERLY, 1973: 8). Os caracteres dessa estranha escrita abstrata “não representam estruturas fonéticas ou especificamente lingüísticas”, conforme a autora; não constituem uma língua, mas “uma forma de linguagem”, cujos elementos “poderão ter valor metafórico na medida do seu valor sinalético, semiológico, icônico” (idem).

E. M. de Melo e Castro considera os Mapas da Imaginação e da Memória um “livro de poemas caligráficos, cujos referentes arqueológicos deverão ser encontrados nos versos figurados da tradição latina e medieval” (HATHERLY, 1992: 100), e insere o "alfabeto estrutural” em que são escritos na linha das "construções utópicas”, pelo fato de

\footnotetext{
${ }^{28}$ A expressão "alfabeto estrutural" foi utilizada pela primeira vez por Ana Hatherly em texto publicado na revista OPERAÇÃO 1, de 1967; hoje, segundo a autora, seria mais precisa a definição de um "alfabeto conceitual” (HATHERLY: 1973, 6)
} 
os seus caracteres "efetivamente não servirem para comunicar senão a sua própria existência, como potenciais meios de estabelecer contatos organizados entre a mente dos homens e as coisas que eles próprios fabricam” (idem, 98).

A relação entre sentido e representação plástica, nesta série de grafismos, pode ser entendida também como o encontro entre um vocabulário de formas presente na memória e a sua metamorfose combinatória pela intervenção do jogo imaginativo, que cria outras possibilidades de grafia e significação, que não obedecem a uma gramática ou a uma lógica normativas. Manuel Castro Caldas, no texto O estatuto do calígrafo - obra visual de Ana Hatherly, identifica, nessa pictografia imaginada, "modos particulares de acumulação, sobreposição, encadeamento e interação de linha e mancha”, que podem seguir "a lógica gráfica de pequenos acidentes e pausas inerentes à escrita” (HATHERLY, 1992: 107), e ainda “certos efeitos pictóricos de textura ou contraste” que "podem lembrar rasuras, encavalitar de linhas, miniaturização” (idem). Ana Hatherly, conclui o crítico, "reinventa pois, experimentalmente, uma dimensão da escrita eminentemente prática, e por isso aberta à constituição de produtivas ligações com a imagem” (idem).

Conforme a poeta portuguesa, “a escrita nunca foi senão representação: imagem. Imaginar é igual a codificar: a escrita surge como um sistema de sinais para indicar um roteiro específico, o que faz com que toda a página escrita seja um mapa” (HATHERLY, 1973: 9). Seguir os trajetos sugeridos nesses labirintos pictóricos é o desafio para o leitor, que reinventa o sentido dos grafismos a cada nova operação de leitura. Conforme escreveu E. M. de Melo e Castro,

a questão da legibilidade é também totalmente secundária (...). É que ler, nesse caso, parece não ser decifrar... Também, sob um ponto de vista semiótico, não devemos procurar nestes poemas caligráficos, nem índices nem ícones. Apenas uma relação convencional aleatória se estabelece entre os textos e a sua caligrafia, o que lhes dá uma natureza simbólica, embora esvaziada de qualquer sentido, além da sua própria 
representação, visto que não se descortina a lei dessa relação convencional. Tende-se, assim, para um vazio semiótico, em que as imagens funcionam quase exclusivamente como materializações dos representamen, ou seja, das cargas psicológicas e emocionais desligadas de qualquer intenção significativa. As caligrafias são objetos escritos, dos quais emana a sua própria substância. (HATHERLY, 1992: 102-103)

Na série de desenhos intitulada Anagramas, que integra os Mapas da imaginação e da memória, exposta na galeria Quadrante, de Lisboa, em 1969, Ana Hatherly estabeleceu um diálogo criativo com a escrita latina, mas "fazendo a abstração do conhecimento da língua que ela podia representar e à qual estava ligada. Para tal, tornei a minha própria escrita ‘ilegível’, a fim de poder observá-la apenas gestualmente” (HATHERLY, 1973: 9), recuperando o caráter puramente visual das escritas arcaicas, bem como o trabalho de registro manual dos caracteres, à maneira dos calígrafos, até sentir “a minha mão tornar-se inteligente ${ }^{29 ”}$ (idem, 5).

Melo e Castro já apontou esse caráter artesanal da escrita criativa de Ana Hatherly em seus próprios instrumentos de trabalho, em geral a "tinta de caneta ou tinta da china (menos frequentemente a caneta de feltro e, menos ainda, a esferográfica), quase sempre nas cores tradicionais da escrita corrente: preto, azul, por vezes o sépia, castanho ou vermelho” (HATHERLY, 1992: 106). Quanto aos suportes, por sua vez, “a escala preferencial, quase exclusiva, destas obras, é a do pequeno cartão, do bilhete postal, da folha de caderno de apontamentos (apenas raramente a da folha de bloco de esquiços)” (idem). O título dado a essa série de grafias abstratas também é significativo, pois indica a estratégia estrutural adotada por Ana Hatherly, que buscou um método de organização

\footnotetext{
${ }^{29}$ Convém lembrar aqui uma série de desenhos e pinturas que Ana Hatherly produziu entre 1994 e 2000, publicados no catálogo da exposição Hand made, fazendo um trocadilho entre o fazer manual e as apropriações críticas de objetos do cotidiano realizadas por Marcel Duchamp. Nesta série, como no romance $O$ escritor e nos desenhos de Mapas da imaginação e da memória, a escrita é reinventada em sua dimensão plástica.
} 
semântica similar ao utilizado no anagrama tradicional. Segundo ela, "o modo de construir um anagrama, processo combinatório altamente arbitrário, portanto rico de possibilidades, se poderia tomar por uma generalização possível, paradigmático do ato criador” (HATHERLY, 1973: 9). Ao contrário do que ocorre no emprego rotineiro da língua, no "ato poético criador”, o artista procurará “as combinações não-úteis, isto é, procurará para além da necessidade. Quero dizer: joga. Provoca o acaso, suscita o fortuito, colhe o inesperado mesmo dentro do conhecido, não rejeita o inexplicável, o ambíguo, o incompreensível” (idem).

Em seu depoimento sobre $O$ escritor, Ana Hatherly já afirmara que “a utilização de linguagens não-verbais em sobreposição (ou não) à linguagem verbal veio alargar notavelmente o campo da leitura para fora dos âmbitos geralmente aceitos pela tradição" (HATHERLY, 1979: 110), que perpetua formas estabelecidas de representação e decodificação. O emprego de signos não-verbais, nesse contexto, trouxe "uma dimensão nova, inesperada, aos nossos métodos de leitura, mas a alteração nos hábitos culturais que ela representa está longe de ter sido ainda assimilada” (idem). Ao questionar o caráter meramente utilitário da escrita, a autora recupera ainda o seu sentido misterioso, presente em alfabetos sagrados como o sânscrito, o hebraico ou o rúnico, que define uma relação criativa entre autor, leitor e escritura: nesses territórios lingüísticos e culturais, não se trata apenas de assimilar uma mensagem implícita, mas de interpretar todos os sinais presentes no texto, verbais e visuais ${ }^{30}$.

Escrevendo a respeito da recuperação do arcaico e do sagrado na obra visual da artista portuguesa, Manuel Castro Caldas fala em "função mágica”, "primitivismo” (similar

\footnotetext{
${ }^{30}$ Na poesia japonesa do tipo haicai, por exemplo, "não se lêem apenas as palavras, mas se apreciam o arranjo e a forma dos caracteres, a utilização das pinceladas de tinta e mesmo os espaços deixados em branco", diz Kunio Komparu, citado por Haroldo de Campos em O charme sutil de Hagoromo (CAMPOS: 1993, 13) .
} 
ao de Picasso, fascinado pela estatuaria africana) e ainda em “pilhagem”, que segundo ele é “o reverso de todo colonialismo” (HATHERLY, 1992: 108). Ao se apropriar de formas estéticas de outras culturas, incorporá-las em seu imaginário, em seus textos e desenhos, a artista portuguesa estaria esvaziando-as “de toda finalidade”, e por isso elas seriam “operatórias e livres” (idem).

Retirando de seus contextos históricos a caligrafia chinesa ou a escrita arcaica latina e atribuindo-lhes outros sentidos estéticos e conceituais, a autora estaria criando "um passaporte para a sua própria escrita” (idem). Nesse processo de conquista de um imaginário, de uma “origem” ao mesmo tempo ancestral, mítica e personalíssima, Ana Hatherly investiu na criação de obras em que a escrita reinventada não é apenas “lida” ou “vista”, mas está inserida em formatos móveis ou manipuláveis, como a “Caixa alfabeto”, de 1970, o “Papyro-Rock”, de 1973, em forma de Torá, e a pintura em rolo de papel de cenário, de 1981, que simulava um gigantesco pergaminho. Todas essas peças foram inspiradas em suportes anteriores à idéia ocidental de "livro", e têm como face complementar as instalações criadas pela artista, que expandem no espaço a dimensão labiríntica já presente em sua escrita visual.

“Rotura”, instalação apresentada em 1977 na Galeria Quadrum, recria a atmosfera interior dos labirintos, em que o peregrino se deparava com toda sorte de enigmas, hieróglifos e outros sinais que se apresentavam a ele como desafios à sua capacidade de interpretação. Segundo relata Ana Hatherly, a sala dessa instalação foi “pintada de preto e sobre as suas quatro paredes colei cartazes brancos, ou melhor, em branco, que depois foram lacerados e semi-arrancados dessas mesmas paredes, deixando-se ficar os fragmentos de papel caídos dessas lacerações” (HATHERLY, 1992: 76). 
O jogo de claro-escuro era reforçado pela iluminação de pequenos projetores, parcialmente velados, que "acendiam e apagavam intermitentemente, de modo a que os relevos criados pelas lacerações, ou seja, o jogo de relevos e de sombras, fosse ora acentuado ora atenuado, dando ao conjunto uma espécie de pulsação, um ritmo vibratório” (idem). Esse ambiente de quase penumbra e superfícies de papel laceradas retratava, de forma alegórica, a situação posterior à Revolução dos Cravos de 25 de Abril, que colocou fim à ditadura salazarista, iniciando um período de expectativas, transformações e incertezas.

A sala escura “convidava à expressão duma vontade de libertação” (idem, 77), e os espectadores, ao rasgarem as folhas de papel expostas na sala "exprimiam a sua liberdade, a sua euforia, a sua raiva contida” (idem), elementos já representados nos grafismos de $O$ escritor. A experiência propiciada pela instalação de Ana Hatherly recorda a travessia arquetípica nos labirintos tradicionais, em cujo centro acontecia a união simbólica do peregrino com a divindade; traduzida para outro campo simbólico, temos neste espaço geométrico interativo o encontro do espectador consigo mesmo, com a linguagem e com a história ${ }^{31}$.

31 "Na minha obra visual mantive sempre o meu rumo próprio, discreto e até bastante secreto", diz Ana Hatherly. "As instalações e os trabalhos de caráter político foram um momento especial, imposto pelas circunstancias históricas.” (HATHERLY, 1992: 83) 


\section{CAPÍTULO II}

\section{A ESCRITA LABIRÍNTICA DAS TISANAS}

\section{1 - Aspectos estruturais, conceituais e estilísticos}

Tisanas são um conjunto de composições poéticas breves que Ana Hatherly escreve desde 1969, constituído até agora de 463 fragmentos numerados, que a autora chama de poemas em prosa. Foram publicadas seis edições desse livro, entre 1969 e 2006, e a cada nova edição foram incluídos novos textos, que oscilam entre o aforismo, a parábola, a narrativa ficcional, o koan, o verbete de dicionário ou enciclopédia, o diário e a fábula, dispostos de modo aparentemente caótico, descontínuo, sem uma ordem seqüencial linear. Este é um work in progress que desafia a própria classificação dos gêneros literários, bem como a distinção tradicional entre prosa e poesia, em favor da noção de texto ${ }^{32}$.

O caráter híbrido ou miscigenado dessa série de escrituras foi notado por Pedro Sena-Lino, para quem estes “textos inclassificáveis” não se enquadram em "nenhum subgênero literário”, mas, ao contrário, incorporam “vários subgêneros, do poema em prosa ao microconto, até as fábulas” (LINO, 2006). O leitor dessa obra, diz ele, fica desorientado por sua "variedade de registros, subgêneros e temas, sem saber com que aspecto do real, da ficção, do maravilhoso ou da desconstrução (ou de nenhum destes) lida em cada texto" (idem). A ruptura de fronteiras entre os gêneros é sintomática do tempo em que vivemos,

\footnotetext{
${ }^{32}$ Marjorie Perloff escreveu, sobre as parole in liberta do futurismo italiano, um comentário que caberia citar aqui: “não é nem completamente 'verso' nem 'prosa', um texto cuja unidade não é nem o parágrafo nem a estrofe, mas a própria página impressa” (PERLOFF, 1993: 21). Podemos citar também Max Bense: "Faz-se algo na linguagem, deve-se fazer algo com a linguagem. Prosa e poesia são conceitos que caracterizam algo que pode ser feito na linguagem, quando ela já se apresenta pronta, suas formas são conhecidas e dadas, usáveis e consumíveis. Texto é algo que é feito com a linguagem, portanto, a partir da linguagem, algo porém que, ao mesmo tempo, a transforma, acresce, aperfeiçoa, interrompe ou reduz.” (BENSE, 1971: 172)
} 
regido pelo sincretismo da pós-modernidade, que desconsidera limites entre tempos e territórios culturais, como foi apontado por Ana Gabriela Macedo, que afirma:

Vivemos um tempo híbrido, caracterizado pela apropriação, montagem, colagem e fusão entre os vários discursos, os vários textos, sejam eles literários ou visuais, oriundos de campos semânticos e lingüísticos distintos, e até mesmo de épocas distintas. Essa tem sido uma das características mais recorrentes e comumente aceites da pós-modernidade, a abolição de fronteiras entre os campos e as disciplinas. (HATHERLY, 2004: 16)

Em sua pesquisa das formas da narração poética, Ana Hatherly incorpora elementos das mais diversas espécies de texto, inclusive dos bestiários (nas Tisanas 6 a 14, por exemplo, os personagens são insetos, galos, peixes, porcos e serpentes) e das prosopopéias (como na Tisana 15, que narra a saga de duas ervilhas, a Tisana 17, cuja protagonista é uma chave, ou as Tisanas 16 e 18, em que a própria palavra é personagem).

A autora faz incursões na teratologia, criando seres singulares como o papa-sombras (Tisana 63), o homem-triângulo (Tisana 73), o mono-asa (Tisana 83), o homem elástico (Tisana 219), inventa nações fantásticas, seguindo o gênero de Jonathan Swift, como a ilha dos náufragos (Tisana 93), a ilha onde se perdia o tempo (Tisana 94), a ilha de vidro (Tisana 98), a ilha de manteiga (Tisana 191) e o país dos coveiros (Tisana 212).

Em outros fragmentos, parodia verbetes de enciclopédia ("A sabedoria do amor consiste na aprendizagem pelo sofrimento, do prazer nele contido”, diz a Tisana 30; “A civilização consiste em aprendermos a fazer naturalmente tudo o que não é natural”, lemos na Tisana 28), o discurso erudito (como nas Tisanas 370 a 373 e a 377, onde são citados Schopenhauer, Kafka, Benjamin e Lou-Andréas Salomé), a epistolografia (Tisana 2, escrita em francês) ou o livro de memórias, com descrições de sonhos, viagens e visitas a amigos.

A autora portuguesa descreve invenções inúteis ou fantasiosas como a máquina chamada “o suicida” (Tisana 54), em que uma bolinha percorre um aparelho engenhoso até cair num buraco e produzir o som TILT; o jogo de xadrez sem pedras, que deve ser jogado 
no escuro para a “descoberta tateante” das peças ausentes (Tisana 71); a escada mole, por onde “ninguém conseguia descer a não ser caindo”, e a escada elástica, “que não só não cansava nada como devolvia os que subiam instantaneamente ao nível da partida” (Tisana $82)^{33}$. Ela recria elementos da natureza, transformados em objetos e seres inverossímeis como a "lagosta cúbica” (Tisana 225), o “ninho de gelo (Tisana 227) ou o "letramoto" (Tisana 268); imagina ações irrealizáveis, relacionando-as de modo irônico com a noção de verdade, que orienta a nossa concepção do real: “querer tocar com a mão as alturas; secar o mar; defender a verdade; acreditar no crer” (Tisana 290). Estas insólitas operações verbais, que alteram o sentido e a função de palavras e coisas, confirmam a visão criativa da autora, para quem “o que resta da natureza é só ponto de partida para a invenção” (Tisana 225).

Há nas Tisanas um violento antilirismo, a recusa da “sinceridade”, ou “verdade sentidamente biográfica”, no dizer de Sena-Lino (LINO, 2006), em favor do engenho formal e imaginativo. Não por acaso, a epígrafe do livro é um adágio de Epimênides de Cnossos que diz: “Todos os cretenses são mentirosos e nunca deixam de mentir”, indicando, já no pórtico da obra, a negação de uma suposta “verdade”, valorizada por uma poesia de índole subjetiva. Conforme diz a autora, “as Tisanas pertencem a um mundo criado pelo discurso, construído pelas palavras. É o mundo da criatividade onde o autor surge como um cego a quem é dado ver numa pequena pausa fria (T. 262). As Tisanas são uma meditação poética sobre a escrita como pintura e filtro da vida” (HATHERLY, 1997: contracapa).

A palavra filtro, aqui, remete ao próprio título do volume: tisana, termo que deriva do grego ptisáne, pelo latim ptisana, significa, conforme os dicionários, “cozimento de cevada”; “medicamento líquido que constitui a bebida comum de um enfermo”

\footnotetext{
${ }^{33}$ Os sonhos, jogos, viagens e invenções inúteis são alguns dos temas constantes de Ana Hatherly, que iremos encontrar, por exemplo, nas pequenas narrativas de seu diário de sonhos, Anacrusa.
} 
(HOLLANDA, 1986: 1682), ou, segundo a própria autora, “infusões” — e não “efusões”, ou excessos líricos ditados pela inspiração (HATHERLY, 2006a: 14), próprios de um romantismo anacrônico em relação às poéticas da modernidade, satirizado na Tisana 35: “ah era poeta liricamente eu estava no estado privilegiado de sintonia e não sei talvez desejasse evocar a antiga lira dizer o que nunca me permiti dizer sabes palavras como saudade é a primeira vez que escrevo coisas assim”, texto paródico construído de modo similar ao fluxo de consciência joyceano, sem sinais de pontuação (idem, 33) ${ }^{34}$.

Tisana é um composto com finalidade terapêutica e poderíamos dizer que, neste livro, trata-se de um irônico medicamento elaborado para despoetizar a poesia, pelo uso da prosa em vez do verso e pela recusa de uma retórica do eu, que cede lugar à pintura de eventos. A palavra tisana também nomeia o gênero poético criado pela autora a partir da mescla singular de outros gêneros, numa escrita que incorpora os recursos estilísticos da poesia de vanguarda, como o uso exclusivo de letras minúsculas em algumas seções, a elipse e o uso não-gramatical da pontuação, além de tropos tradicionais como o oxímoro, a hipérbole e a metonímia. Cada peça tem como título apenas um número e por vezes epítetos citados no interior de cada texto, e assim temos a tisana do amor sem par (293), a tisana de preço fantástico (294), a tisana de amor tranqüilizante (295), a tisana do tempo (339), a tisana dos vizinhos (342), a tisana do sofrimento (382) e a tisana da mulher (409), entre outras, de extensão desigual, nem sempre identificadas com essa nomenclatura.

O deslocamento geográfico é um tema recorrente ao longo do volume (“Passei anos de minha vida nas salas dos aeroportos à espera de autorização para levantar vôo”, diz a Tisana 384). São numerosas as referências a viagens aéreas, estações, hotéis e também a

\footnotetext{
${ }^{34}$ Em O Anagramático, Ana Hatherly diz: "enquanto os meus colegas propõem soluções eu proponho infusões: TISANAS! É que não sendo um romântico sou todavia um químico” (HATHERLY, 1980: 213).
} 
cidades visitadas, como Amsterdã, Praga, Varsóvia, Cairo, Antuérpia, Bombaim, sugerindo de modo metafórico que toda escrita é um movimento incessante, descoberta de novas paisagens e mescla de diferentes repertórios culturais ${ }^{35}$.

O espaço narrativo nas Tisanas é múltiplo e a dimensão temporal, indeterminada: não há qualquer referência cronológica dos eventos, ao contrário dos registros habituais na memorialística e nas obras ficcionais tradicionais, o que nos faz recordar um comentário de Michel Butor sobre a Comédia Humana de Balzac:

Trata-se do que se poderia chamar um móbile romanesco, um conjunto formado de um certo número de partes que pode ser abordado quase que na ordem por nós desejada; cada leitor traçará (...) um trajeto diferente; é como uma esfera ou recinto circular com muitas portas” (CAMPOS, 1976: 28)

definição que recorda a do labirinto destituído de centro, a que nos referimos no primeiro capítulo. A mobilidade está presente no próprio processo de composição da obra, que a cada nova edição é igual e diferente de si mesma: a primeira edição do livro surgiu em 1969, com o título de 39 Tisanas; no ano seguinte, sai uma nova edição, intitulada 63 Tisanas, e até 2006 sairiam mais quatro distintas versões da obra, sendo a mais recente as 463 Tisanas, livro que inclui também três “proto-tisanas” e duas “quase-tisanas”.

Trata-se, portanto, de uma obra em metamorfose contínua e incessante escritura, que faz do provisório “a sua própria categoria de criação, pondo em questão (...) a idéia mesma de obra conclusa, instalando o transitório onde, segundo uma perspectiva clássica, vigeria a imutabilidade perfeita e paradigmal dos objetos eternos”, para citarmos comentário de Haroldo de Campos sobre o Livro inacabado de Mallarmé (CAMPOS, 1976: 19). Ao fazer da mutabilidade a sua própria concepção estrutural, as Tisanas refletem a

\footnotetext{
${ }^{35}$ Rogério Barbosa da Silva afirma, a esse respeito: “Itinerários tornou-se título de um dos últimos livros da autora, no qual evoca, de imediato, a referência a suas viagens por inúmeros países e culturas, ainda que pudesse também sugerir as suas contínuas viagens em torno da escrita e de suas próprias obras: poéticas, ficcionais, visuais e de crítica” (HATHERLY, 2004: 25)
} 
idéia da realidade como devir, rio heraclítico sempre igual e diferente de si mesmo. O movimento é o fio condutor que percorre todos os fragmentos que compõem o volume, onde nada aparenta ser estático. “Todas as tisanas relatam um acontecimento”, diz a autora, “são um acontecer ou um acontecido" (HATHERLY, 1997: contracapa).

As ações podem ser banais ou inesperadas, verossímeis ou inverossímeis, concluídas ou apenas esboçadas, mas constituem o núcleo central em torno do qual se desenvolve cada trama poética. Na Tisana 1, a ação se resume ao passeio de uma criança pelo campo até se encontrar a porta de uma quinta, onde há um cão enorme; na Tisana 7, uma barata escorrega suas patas em malas de fibra; na Tisana 163, lemos este microrrelato:

Era uma vez um caramujo que vivia feliz em cima duma panela de água a ferver. Quando apagavam o lume passava a sofrer de insônias. (HATHERLY, 2006a: 79)

Nenhuma dessas ações tem um caráter linear, de feitio realista; ao contrário, como diz Nadiá Paulo Ferreira, “a narração engendra encenações que cercam uma tentativa de dizer o impossível de ser dito, ou seja, o que Jean-Michel Ribettes denomina fantasia real” (FERREIRA, 1993: 350). Ana Hatherly enfoca o que "há de involuntário nos gestos habituais”, sabendo que em “cada acto” há uma “fantástica abstração” (Tisana 58).

Sua arte fabulatória caminha no sentido inverso ao da mímese aristotélica, que orientou o pensamento estético de numerosos retóricos ao longo da história literária, como é o caso de Boileau, que na Arte Poética defende que os tropos sejam "clairs, modestes, raisonables”, conforme diz Fernando Guimarães em artigo publicado na revista Claro Escuro (Guimarães: 1990, 46). A ordem e a clareza da obra de arte clássica estavam relacionadas à idéia de uma razão ordenadora no universo, razão que, conforme Guimarães, “a filosofia medieval tenderá a identificar com Deus” (idem). Se o universo estava sujeito a um logos, a arte, da mesma maneira, deveria "se subordinar à natureza e à razão. É este um 
dos princípios definidos pelos preceptistas do século XVII — e também do século seguinte —, nos quais se faz sentir, não raro, a influência dos comentadores seiscentistas italianos de Aristóteles” (idem). A “estética da imitação” do classicismo, porém, é perturbada pelo barroco, que coloca em xeque o princípio ordenador da razão, "que regula e limita os poderes da ficção da poesia, isto é, o seu espaço imaginativo” ${ }^{36}$ (idem), escreve Guimarães.

A revolta contra o equilíbrio, clareza e objetividade da arte clássica pela irrupção de uma outra racionalidade, cifrada e metafórica, que não busca apenas retratar a aparência imediata dos fenômenos, continua na poética da modernidade, na qual, diz Guimarães, a “desrealização a que se sujeita o discurso poético — deslocando-o, como vimos, do espaço mesmo da referencialidade — acaba por consignar ou propor uma outra forma da realidade que se identifica como a das formas verbais ou de um imaginário”, ou seja, o caráter metalingüístico se sobrepõe a “qualquer rígido suporte de natureza referencial” (idem, 48).

É neste sentido que podemos interpretar os relatos de Ana Hatherly, como as Tisanas, Anacrusa ou $O$ mestre: no lugar da referencialidade que obedece a uma concepção lógica de origem aristotélica, temos a construção de imaginários autônomos que se relacionam a outras visões de mundo, como a mecânica quântica e o pensamento zen.

\section{2 - Descontinuidade e assimetria}

Todos os temas referidos nas Tisanas são organizados em séries, dispostas no livro de maneira assimétrica, assistemática, acronológica, com cruzamentos, variantes e interpolações temáticas e estilísticas fora de uma ordem do tipo início-meio-fim. Podemos citar aqui Ana Marques Gastão, para quem Ana Hatherly “recusa o espírito de sistema,

\footnotetext{
${ }^{36}$ Na poesia barroca, as metáforas, por exemplo, são usadas não mais para simbolizar as coisas, e sim por seus efeitos estéticos, que “representam sempre um desvio em relação ao nome em questão” (idem, 48).
} 
aderindo a uma estética do fragmento, ao pensar experimental, descontínuo” (GASTÃO, 2006), e também Umberto Eco, quando se referia à "desordem fecunda” na obra de arte contemporânea, que significa a "ruptura de uma ordem tradicional, que o homem ocidental acreditava imutável e identificava com a estrutura objetiva do mundo” (ECO, 1976: 23).

O espelhismo entre as novas visões da realidade trazidas pela física quântica, que sucedeu ao "rígido determinismo da física clássica, com sua correlata noção de certeza" (CAMPOS, 1977: 16), e as formas estéticas da vanguarda está presente na idéia de que "os conceitos clássicos de continuidade, de lei universal, de relação causal, de previsibilidade dos fenômenos” (ECO, 1976: 205-206) caíram por terra, dando lugar a outros conceitos, como a ambigüidade, a descontinuidade, a assimetria, o indeterminado, a probabilidade ${ }^{37}$.

Werner Heisenberg, que formulou o princípio da incerteza, afirma que, "no campo atômico, estamos lidando com outra estrutura de espaço-tempo, e, muito especialmente, com uma relação diferente entre o tempo e o espaço” (HEISENBERG, 1996: 117), onde as leis de Newton não se aplicam, uma vez que elas são válidas "quando falamos do tempo absoluto, isto é, do tempo que parece independer da posição e do estado de movimento do observador, e enquanto lidamos com corpos rígidos (...) que têm um dado volume” (idem).

Quando considerarmos "processos que envolvem velocidades enormes e, ao mesmo tempo, tentamos fazer medições muito precisas”, escreve o físico alemão, "descobrimos que a mecânica newtoniana já não fornece uma descrição adequada” (idem). Nos domínios em que as fórmulas da física clássica não se aplicam, conclui, "precisamos de estruturas

\footnotetext{
37 "Probabilidade gera incerteza. No caso de um elétron, ou de qualquer outro objeto quântico, só podemos falar na probabilidade de descobrir o objeto nesta ou naquela posição, ou no seu momentum (massa multiplicada por velocidade), mas essas probabilidades formam uma distribuição, como a que é representada pela curva campanular. A probabilidade será máxima para algum valor da posição e este será o local com maior probabilidade de encontrarmos o elétron. Mas haverá uma região inteira de locais onde será grande a probabilidade de localizá-lo. A largura dessa região representa o grau de incerteza da posição do elétron.” (GOSWAMI, 1993: 145)
} 
conceituais inteiramente novas, como, por exemplo, as introduzidas pela teoria da relatividade ou pela mecânica quântica” (idem). Segundo o físico indiano Amit Goswami,

Na física clássica, todo movimento é determinado pelas forças que o governam. Uma vez conheçamos as condições iniciais (a posição e a velocidade de um objeto em algum instante inicial do tempo), podemos calcular-lhe a trajetória precisa, usando as equações de movimento de Newton. A física clássica, dessa maneira, leva à filosofia do determinismo, à idéia de que é possível prognosticar inteiramente o movimento de todos os objetos materiais. (GOSWAMI, 1993: 145)

No entanto, prossegue o autor, "não podemos simultaneamente determinar, com certeza, a posição e a velocidade (ou momentum) de um elétron; o menor esforço para medir exatamente um deles torna vago nosso conhecimento do outro” (idem). A conclusão da nova teoria afasta-se profundamente da lógica newtoniana: “As condições iniciais para o cálculo da trajetória de uma partícula, portanto, jamais podem ser determinadas com precisão, e é insustentável o conceito de trajetória nitidamente definida de uma partícula” (idem). Comentando o princípio da incerteza, escreve Umberto Eco no livro Obra aberta:

o homem ocidental aprendeu que o Acaso domina a vida do mundo subatômico e que as leis e previsões pelas quais nós nos fazemos guiar para compreendermos os fenômenos da vida cotidiana são válidas unicamente por expressarem médias estatísticas aproximadas. A incerteza tornou-se um critério essencial para a compreensão do mundo (...) Sabemos que qualquer descrição nossa dos fenômenos atômicos é complementar, que uma descrição pode opor-se a outra, sem que uma seja verdadeira e a outra falsa. (...) A incerteza e a indeterminação são uma propriedade objetiva do mundo físico. (ECO, 1976: 224).

Este novo paradigma encontra paralelos na criação artística em obras como Finnegans Wake de Joyce, o Livro de Mallarmé, as composições musicais de John Cage, Pierre Boulez e Stockhausen, os móbiles de Calder, e é nesta seara que podemos incluir as Tisanas, texto de invenção desenvolvido sob o signo da ambigüidade — que é, na opinião de Roman Jakobson, “característica intrínseca, inalienável, de toda mensagem voltada para si própria, em suma, num corolário obrigatório da poesia” (JAKOBSON, 1969: 120). 
Conforme diz o verbete de dicionário, o termo ambíguo pode ser entendido como “indeterminado", “impreciso”, “equívoco”, “indeciso”, "imprevisível” e “com duplo sentido” (HOLLANDA, 1986: 102), acepções relevantes para a compreensão dessa poética instável e plurívoca. Baltasar Gracián, citado por Affonso Ávila em seu livro O lúdico e as projeções do barroco, define a ambigüidade como "una palabra de dos cortes y un significar a dos luces” (ÁvILA, 1994: 90); e a própria Ana Hatherly, no capítulo inicial do romance $O$ Mestre, define ambigüidade como “a Arte do Suspenso. Tudo o que está suspenso suspende ou equilibra. Ou instabiliza. Mas tudo é instável ou está em suspenso” (HATHERLY, 2006b: 21). O demônio da ambigüidade manifesta-se desde o aspecto conceitual das Tisanas até o estrutural e o temático; inclusive as personagens, ou vozes dramáticas, estão situadas fora da órbita mimética, com a despersonalização de quem fala e a alteração das funções ou características de pessoas, objetos e cenários ${ }^{38}$.

As narrativas são realizadas, em sua maioria, na primeira pessoa (com algumas ocorrências na terceira); porém, o narrador não é nomeado, assim como outros personagens próximos a ele, com poucas exceções, como o porco doméstico Rosalina, que assume eventualmente ações humanas, como ler a transcrição de um telefonema, datilografar, ir ao salão de beleza ou à agência dos correios (Tisanas 10, 11 e 29). De maneira similar, a própria narradora assume as lides de uma abelha, entrando numa loja para comprar pólen, com o objetivo de fabricar mel (Tisana 23).

A troca de papéis entre o humano e o animal, o cerebral e o sensorial, é comentada por Elfriede Engelmayer, para quem “é com o porco Rosalina que as Tisanas destroem de

\footnotetext{
${ }^{38}$ Herberto Helder, no primeiro número dos Cadermos de Poesia Experimental, escreve que “ambigüidade, indefinibilidade e polivalência do real são testemunhadas, no plano da representação estética, pela experimentação e o encontro sucessivo, determinados por desajustamentos e ajustamentos entre a imaginação e a realidade” (HATHERLY, Ana, e MELO E CASTRO, E. M.: 1981, 58).
} 
modo mais radical (embora disfarçado pelo anagrama), e com profundo humor, as fronteiras hierárquicas entre ser humano e animal” (HATHERLY, 2004: 67). Segundo a ensaísta, com o anagrama porco/corpo, Ana Hatherly representa, de forma irônica, a “distinção arbitrária entre espírito dominador e corpo dominado com que a tradição cristã divide ao meio o in-divíduo" (idem). Rosalina, o “porco cético”, seria ao mesmo tempo uma “duplicação do eu” e um “ser autônomo”, com quem a narradora dialoga, num “jogo verbal” (idem) cujo clímax seria atingido na antifábula da Tisana 302, em que a devoração do outro assume o caráter de um ritual doméstico:

Hoje é o dia dos meus anos. Tenho de celebrar. Vou ao supermercado e compro costeletas de porco em homenagem a Rosalina. Em todos os gestos úteis há sempre algo de terrível (HATHERLY, 2006a: 117).

Esse fragmento, que pode ser lido à luz da psicanálise ou da tradição literária do Duplo, é um exemplo de como a sensação de estranheza, nas Tisanas, é obtida pela alteração, deslocamento ou deformação do sentido de palavras e ações, numa reconfiguração semântica distinta das operações léxicas e sintáticas de ordem neológica realizadas por Haroldo de Campos nas Galáxias e Paulo Leminski em Catatau, na literatura brasileira. Ana Hatherly adota uma outra estratégia, atribuindo à semântica novos conteúdos e rotas de leitura: “as palavras estão pervertidas porque são cúmplices da infelicidade dos homens e só pode haver liberdade na transgressão” (Tisana 62).

\section{3 - A “técnica de destruição da certeza”}

A ironia é um elemento essencial ao jogo proposto pelas Tisanas, que utiliza uma “técnica de destruição da certeza” e uma “indeterminação deslizante” (HATHERLY, 2006a: 14) para perturbar a estabilidade das formas de representação no discurso, sugerindo que a nossa visão da realidade é um reflexo do modo como organizamos a linguagem e o 
pensamento, tema caro à doutrina $\mathrm{zen}^{39}$. Para Maria João Fernandes, as Tisanas questionam

não só o sentido do real, como o sentido e a forma da linguagem e da própria literatura. A realidade motiva, determina, as palavras, mas as palavras também criam a realidade, propõem-lhe um novo espelho, onde sua imagem se reflete, inseparável da interioridade do sujeito (HATHERLY, 2004: 75).

O mundo seria uma representação derivada de nossa maneira de perceber e nomear as coisas, e a linguagem, ao mesmo tempo em que é condicionada pelo mundo, cria outros mundos, como representação simbólica ${ }^{40}$. As tensões entre subjetivo e objetivo, palavra e coisa, verdadeiro e falso são um tema recorrente em Ana Hatherly, que, para concretizar a meta de questionar noções convencionais de arte e mundo, parodia (no sentido grego da palavra, “canto paralelo”) a forma narrativa dos koans, em que o humor e o non sense são utilizados para perturbar a lógica habitual do discurso e, com isso, abalar nossa visão rotineira da realidade, permitindo a compreensão intuitiva e imediata dos fenômenos.

Fritjof Capra escreve que “os koans são enigmas absurdos, cuidadosamente preparados com o fito de fazer com que o estudante do Zen se aperceba, do modo mais dramático, das limitações da lógica e do raciocínio” (CAPRA, 1989: 44). Conforme o físico

\footnotetext{
39 O zen-budismo, ao contrário de outras escolas derivadas do pensamento de Sidarta Gautama, o Buda, não valoriza o estudo das escrituras, o cerimonial litúrgico, a devoção ou mesmo a meditação, ainda que esses elementos estejam presentes na rotina monástica. O que caracteriza a experiência zen é o caminho "em direção a um despertar (satôri, no japonês), uma iluminação, indescritível e intransferível”, escreve Leminski, em sua biografia de Bashô (LEMINSKI: 1983, 71). O zen-budista busca ultrapassar a percepção de um eu individual como entidade permanente e separada do mundo, assim como as dicotomias tradicionais entre palavra e coisa, sujeito e objeto, interior e exterior. Conforme Georges da Silva, "o intelecto habitualmente separa o fato do conceito. O budismo ch'an ou zen procura conseguir um estado mental acima da mente perceptiva” (SILVA, Georges, e HOMENKO, Rita: 1993, 241). Para o zen-budista, “a Verdade é encontrada em qualquer lugar e a toda hora; não é algo exterior, fora de nós; ela está onde nós estamos” (idem, 241-242). Esta Verdade é entendida como o fluir de eventos incessantes, mutáveis e impermanentes, que em sua essência última não se diferenciam da natureza do sonho, já que a natureza de todas as coisas é a Vacuidade.

40 “As idéias e pensamentos não são independentes do mundo exterior onde atuam os cinco sentidos”, afirma Georges da Silva, a respeito da teoria do conhecimento na filosofia budista; ao contrário, "fazem parte do mundo em que vivemos e são produzidos e condicionados por sensações de natureza física" (SILVA, Georges, e HOMENKO, Rita, 1993: 45).
} 
austríaco, que estudou os paralelos entre a mecânica quântica e as filosofias do Oriente, o caráter irracional, paradoxal desses enigmas "torna impossível a sua decifração através do pensamento. Os koans são elaborados precisamente para parar o processo do pensamento e, dessa forma, preparar o estudante para a experiência não-verbal da realidade” (idem).

“O koan pode ser descrito como um problema apresentado pelo mestre a seu discípulo”, diz o pesquisador brasileiro Georges da Silva. “Consiste numa frase, às vezes ilógica e risível; é um exercício especial, cuja finalidade é ativar a mente, pela qual o discípulo chega à compreensão intuitiva da verdade” (SILVA, Georges, e HOMENKO, Rita: 1993, 236). Um exemplo clássico de koan é a pergunta “qual é o som de uma única palma?”, cuja resposta é o silêncio. O koan também pode acontecer na forma de diálogo, como sucessão de perguntas e respostas paradoxais (o mondo), ou ainda como histórias tradicionais que desconcertam as expectativas habituais da racionalidade ${ }^{41}$.

Conforme diz Leminski, "há centenas de koans, reunidos em grandes coleções, com os ditos e feitos dos mestres mais famosos” (LEMINSKI, 1983: 73). Nos mosteiros zenbudistas, esse tipo de enigma verbal era transmitido pelo mestre a seu discípulo, para que este “concentre-se, durante um tempo que pode ser longo, trabalhando mentalmente sobre ele, absorvendo sua 'outra lógica’” (idem). Como ilustração dessa singular variante da parábola, que recorda os ensinamentos dos filósofos cínicos gregos, como Diógenes, que caminhava à luz do dia com uma lanterna, à procura de um homem honesto (idem, 72), Leminski cita o seguinte koan em seu livro Bashô, a lágrima do peixe:

${ }^{41}$ Os mestres chineses podem usar ainda outros métodos de treinamento da mente, como esbofetear o discípulo, aplicar-lhe um golpe de bastão, cuspir ou gesticular de modo incompreensível. Todas essas práticas, adotadas nos mosteiros zen, são formas para se romper com a rotina da mente, que separa sujeito e objeto, indivíduo e universo, criando categorias mentais que apenas alimentam a ignorância. "O budismo ch'an ou zen procura conseguir um estado mental acima da mente perceptiva; quanto mais amplo for o uso de palavras, tanto maior será a tendência para a confusão” (SILVA, Georges, e HOMENKO, Rita, 1993: 241). 
Po-chang tinha tantos alunos que se viu obrigado a abrir outro mosteiro. Para achar alguém apto a ser mestre na nova casa, juntou seus monges e colocou um cântaro na frente deles, dizendo:

— Sem o chamarem de cântaro, me digam o que é isso.

— Você não pode chamá-lo um pedaço de lenha, disse o monge principal.

Nesta altura, o cozinheiro do mosteiro derrubou o cântaro com um pontapé e afastou-se. Po-chang deu a direção do novo mosteiro ao cozinheiro. (LEMINSKI, 1983: 72).

Taisen Deshimaru apresenta uma história tradicional sobre a desavença entre a cabeça e o rabo de um animal, que não chegavam a um consenso sobre quem deveria seguir atrás e quem caminharia na frente. Após uma discussão, a cabeça cede o seu privilégio ao rabo, mas, como este não tinha olhos, caiu num buraco e ambos morreram na queda (DESHIMARU, 1983: 33).

Outra narrativa coletada por Deshimaru conta a história de um pássaro de duas cabeças, ambas gulosas, que viviam em desavença por causa da disputa por comida. A cabeça da esquerda, querendo todo o alimento para si, incita a cabeça da direita a ingerir uma erva venenosa, acreditando que com a morte da rival ficaria enfim livre para comer tudo o que desejasse; porém, o veneno causa a morte das duas (DESHIMARU, 1983: 32).

Os koans “causaram-me uma profunda impressão”, diz Ana Hatherly, “e, em termos estruturais, deixaram sua marca na minha concepção das Tisanas” (HATHERLY, 2006a: 13), o que fica nítido, especialmente, na Tisana 12:

Era uma vez duas serpentes que não gostavam uma da outra. Um dia, encontraram-se num caminho muito estreito e como não gostavam uma da outra devoraram-se mutuamente. Quando cada uma devorou a outra não ficou nada. Esta história tradicional demonstra que se deve amar o próximo ou então ter muito cuidado com o que se comer (sic). (HATHERLY, 2006a: 23)

Há numerosas afinidades estilísticas entre o koan e a tisana como o humor, o paradoxo, a ação súbita, a aparente simplicidade textual e as definições por meio de 
imagens enigmáticas ${ }^{42}$. Ana Hatherly afirma que o "gosto pela decifração” se baseia "num conceito de que o significado do mundo é oculto (...) e nos obriga ao constante esforço da escolha através da interpretação”. (HATHERLY, 1983a: 222).

A obtenção da sabedoria por meio da decodificação de enigmas e paradoxos é a meta do koan, mas, ao contrário da relação entre o espectador e a obra de arte no período barroco, em que o enigma poderia ser decifrado por quem conhecesse certo repertório de símbolos, na relação do discípulo com o koan impera a perplexidade, já que nesse caso o enigma não tem respostas previamente estabelecidas, mas oferece, a partir de sua enunciação, toda sorte de experiências imaginativas, verbais ou não-verbais, que solucionam a questão proposta de forma inusitada, intuitiva e não racional ("Voltemos ao Koan. O que é o sentido? Uma mala fechada que nunca teve fecho. Eis a ironia da humildade”, diz a Tisana 275).

Podemos considerar o koan como um mecanismo sutil que conduz a uma pluralidade de rotas de leitura e de construção de significados (assim como ocorre na obra aberta), e não como um mistério decifrável a partir de uma única via interpretativa.

\section{4 - Diálogos entre a poesia e a pintura}

A pintura é uma peça-chave na concepção das Tisanas — não por acaso, a autora se define como um “poeta-pintor” na Tisana 348, ou ainda como “criadora de imagens” e “artista visual” (HATHERLY, 2005: 106), cujo projeto artístico se insere "numa longa

\footnotetext{
${ }^{42}$ Um recurso similar ao koan, citado por Joan Huizinga em seu livro Homo ludens - O jogo como elemento da cultura, é o jogo de perguntas e respostas enigmáticas da tradição védica, que seriam similares às "adivinhas de salão" mas com um sentido sapiencial e sagrado, por isso mesmo inseridas em "competições rituais de enigmas”. (HUIZINGA, 2007: 120) Também os Eddas, relatos mitológicos escandinavos, fazem uso do enigma sapiencial, como relata Huizinga (idem, 124).
} 
tradição de poetas-pintores-calígrafos, criadores de imagens mais ou menos diretamente ligados à escrita como pintura de signos” (idem, 113).

A escritura, diz Ana Hatherly "é uma forma de materialização do imaginário” (idem, 107). "Seja qual for o tipo de escrita, visual, sonora, gestual, seja qual for o tipo de suporte, estamos sempre ante imagens codificadas” (idem). Toda codificação, por sua vez, requer um trabalho de decodificação "para que a comunicação se estabeleça, mesmo que essa comunicação deseje comunicar a sua incomunicabilidade” (idem), numa atividade lúdica entre criador e receptor. A relação entre pintura e poesia é mais evidente em trabalhos como o romance gráfico O escritor (1975), composto unicamente de linhas, cores, traços, sombras e letras inseridas no papel, ou ainda na série de desenhos caligráficos Mapas da imaginação e da memória (1973), elaborados a partir de estudos da escrita ideográfica chinesa, que abordamos no primeiro capítulo deste trabalho. Nas Tisanas, a relação com a pintura é de outra natureza, mais implícita ou no plano referencial: temos aqui a aglutinação de imagens e símbolos verbais de modo alegórico, com a "prática constante do contraste e do exagero”, o “culto da retórica da imagem” (HATHERLY, 1997: 17) e um sentido lúdico que rege a combinação das formas, como um demiurgo secreto.

A representação de seres e eventos, nessas narrativas poéticas, obedece a uma “lógica da metamorfose”, para citarmos uma expressão de Claudio Willer a respeito dos Cantos de Maldoror (LAUTRÉAMONT, 2004: contracapa), que altera e recombina o caráter e as funções dos objetos, numa operação de linguagem que recorda por vezes Arcimboldo ${ }^{43}$ (“Era uma vez um mar de espaguete em que as praias eram de arroz doce”, lemos na

43 "Arcimboldo é o exemplo típico da imitazione fantástica que em Praga pintara figuras humanas, aproveitando-se de frutas, plantas, animais e de outros objetos", escreve Gustav Hocke em $O$ mundo como labirinto (HOCKE: 2005, 76). "Arcimboldo apresenta-se como mestre de uma metamorfose total. A força do 'fantástico' tem o direito de aproveitar tudo aquilo que é percebido pelos sentidos, de reuni-lo e compô-lo sob nova forma. Arcimboldo não pinta coisas tiradas da fantasia, mas ele procura relacionar objetos aparentemente incompatíveis.” (Idem) 
Tisana 86; "vejo um grupo de velhos atletas desmobilizados dormindo como uvas em cacho", diz a Tisana 62; o artista é ainda citado nominalmente nas Tisanas 58 e 130), e mesmo Lautréamont e os procedimentos surrealistas (“Era uma vez um relógio anacrônico. Quando batia as horas estas rolavam pela sala e depois transformavam-se em lindas maçãs de prata que se penduravam do teto”, Tisana 70).

A imagem poética surrealista, segundo Reverdy, "não pode nascer de uma comparação, mas da aproximação de duas realidades mais ou menos afastadas. Quanto mais as relações das duas realidades forem distantes e justas, tanto mais a imagem será forte, mais força emotiva e realidade poética ela terá” (PIVA, 2005: 150-51). Marinetti expôs o mesmo princípio ao dizer que “a analogia é nada mais do que o amor profundo que associa coisas distantes, aparentemente diversas e hostis” (PERLOFF, 1993: 117). Esta formulação das vanguardas européias, porém, encontra antecedentes históricos no maneirismo — por exemplo, em Tesauro, para quem, nas palavras de Gustav Hocke,

O verdadeiro poeta é aquele que se mostra capaz de estabelecer conexões entre as coisas, ainda que sejam as mais díspares. Tal é, com efeito, a essência dos diversos maneirismos que surgiram na Europa, sob diversas denominações. (...) Na época, a discordia concors de Tesauro mereceu esta explicação na Inglaterra: 'trata-se de uma tentativa de combinar imagens dessemelhantes ou de descobrir as analogias latentes nos objetos entre os quais, aparentemente, não há nenhuma relação mútua’. (HOCKE, 2005: 23-24)

Longe de buscar a alucinação ou o encantatório, Ana Hatherly faz uso da alquimia de imagens e do inverossímil com um sentido irônico, que se aproxima da caricatura e do absurdo intencional, para fazer a crítica do discurso e do conceito vulgar de realidade, ao mostrar as ambigüidades, dissimulações e conflitos entre a forma e o sentido de palavras e situações humanas (e convém aqui lembrar que no pensamento budista, assim como na arte barroca, temos a idéia de que o mundo é uma grande ilusão, um jogo ou um sonho, em comparação com o estado ilimitado da Vacuidade). A poesia aproxima-se da pintura para 
expressar, com intensidade, o caráter mutável, ridículo ou tenebroso da história pessoal e coletiva que costumamos chamar de realidade. Na Tisana 61, a autora aproxima-se de um estilo agressivo, beirando o grotesco, que recorda a tela Boi esquartejado, de Rembrandt ${ }^{44}$ (acervo do Museu do Louvre), ou ainda o trabalho pictórico de Francis Bacon:

Se a vida é como tantos dizem insuportável porque se farão tantos e tão absurdos esforços para a prolongar, pensava eu dirigindo-me para o talho. Entrando no estabelecimento, vejo à minha esquerda uma vitela inteira, viva e de pé mas sem pele nenhuma, com os músculos vermelhos e as inserções dos músculos e dos tendões perfeitamente azuis. Que maneira de conservar a carne fresca penso eu olhando a vitela. Voltando o rosto para o carniceiro que cortava nesse momento alguns bifes vejo que também ele não tem pele alguma sobre a sua própria carne e que os seus músculos, como os da vitela, são intensamente vermelhos e as inserções dos músculos perfeitamente azuis. Mais tarde contei tudo isto aos meus amigos mas eles disseram isso não pode ser (HATHERLY, 2006a: 48).

A utilização de recursos pictóricos na escrita é um tema recorrente na obra de Ana Hatherly, para quem "poesia e pintura convergem num ponto essencial, que não é apenas o da imitação, ligado aos conceitos de verdadeiro e verossímil”, como afirma em O ladrão cristalino (HATHERLY, 1997: 15). A convergência entre escrita e imagem pictórica ocorreria sobretudo no campo da "simbolização, destinada a transmitir os valores morais ocultos nas aparências do real, ou seja, na realidade não imediatamente apercebível pelos sentidos” (idem). No caso da poeta portuguesa, e ao contrário do que acontecia com os artistas barrocos, não existe uma preocupação de índole teleológica, nem a propaganda da salvação eterna, pela representação dramática dos vícios e das virtudes, mas está presente a idéia moral possível em nossa época sem utopias: a liberdade de pensar o mundo, a escrita e a si mesmo como seres mutáveis, híbridos, contraditórios, que não estão fixos ou imobilizados em nenhuma hierarquia ou sistema atemporal de valores. Essa mobilidade é talvez o ponto essencial para a compreensão das Tisanas, uma obra em progresso que

\footnotetext{
${ }^{44}$ No romance $O$ Mestre, Ana Hatherly faz uma citação paródica de outra tela conhecida de Rembrandt, a Lição de Anatomia.
} 
recusa a vocação para o permanente, incorporando a instabilidade e a mutação como eixos de construção formal e de leitura, numa metáfora oblíqua de nosso próprio estar no mundo.

\section{5 - As “Proto-Tisanas” e as “Quase-Tisanas”}

A assimetria, instabilidade e transitoriedade da escritura de Ana Hatherly são mais evidentes nas três “Proto-Tisanas” e nas duas “Quase-Tisanas”, publicadas em anexo no final do volume, que convidam o leitor a fazer uma análise por contraste entre essas unidades inconclusas e o conjunto do ciclo. As afinidades são claras: encontramos aqui a concisão do aforismo, a construção alegórica, a paródia da fábula e da parábola, a ironia, a estética do fragmentário e do inacabado, a narração de acontecimentos cotidianos que adquirem um desenvolvimento imprevisto. Porém, como voluntária dissonância, Ana Hatherly introduz aqui outros ingredientes: as três "Proto-Tisanas”, identificadas cada uma com um algarismo romano, são organizadas em linhas breves, simulando "versos” (ainda que encadeados em seqüência discursiva, como no enjambement); o porco de estimação Rosalina cede ao gato Leonardo o papel de interlocutor da narradora; e o foco central do texto é agora a reflexão, ainda que próxima ao absurdo das peças de Beckett ou Ionesco ${ }^{45}$.

Na primeira “proto-tisana”, escrita em apenas oito linhas, a hostilidade do gato à empregada doméstica é explicada pelo fato desta chamar-se Conceição, e o animal ser amarelo (uma subversão, pelo non sense, da idéia de causalidade); na segunda, um pouco mais extensa, com 22 linhas, a narradora observa uma amostra de sangue ao microscópio, enquanto a água transborda da banheira; e no último texto, com 39 linhas, a autora faz-se

\footnotetext{
${ }^{45}$ No romance $O$ Mestre, há uma referência à peça $A$ cantora careca, de Ionesco. Em entrevista concedida a Ana Marques Gastão, aliás, Ana Hatherly diz que "Quando escrevi $O$ Mestre, Ionesco foi igualmente importante. Tudo passa pela manipulação das palavras, sacralizá-las e dessacralizá-las dir-se-ia um processo fundamental.” (HATHERLY, 2005: 139)
} 
de cientista e se propõe a estudar a impenetrabilidade da matéria, cravando o estilete na coxa de seu animal de estimação. Nestas três peças, o deslocamento da relação causa-efeito é o recurso essencial para desestruturar a idéia de "normalidade” do cotidiano e o próprio conceito de realidade; não por acaso, a autora diz, na Tisana 455: “Em arte a realidade possível é a que nós inventamos”, e, na Tisana 276: “A teimosa realidade. Na arqueologia da paisagem a viagem da escrita é abolição oblíqua, delírio provocado, lição de tentativa”.

Nas duas “Quase-Tisanas”, escritas em prosa e identificadas com códigos de letras e números (VII-C; RL-24.X), a transmutação do real alcança efeitos burlescos com a descrição do temor de um povoado de homúnculos ante o incompreensível anoitecer e o relato do lápis que tenta investigar um sapato, pouco antes de uma enchente imprevista. A impossibilidade de se obter um conhecimento verdadeiro e definitivo sobre as coisas (uma das chaves básicas das Tisanas e também do romance $O$ Mestre), o conflito com a natureza e a dificuldade de comunicação entre os homens são temas que se destacam nessas composições, em que a crítica irônica se articula num campo ficcional alegórico. Como ilustração, citamos aqui a “Quase-Tisana” n. VII-C:

E quando o sol surgiu no horizonte o céu apresentava o aspecto de algo coberto por uma mancha cujos contornos alastravam. Aterrorizados, os homúnculos cobriram a cabeça com os seus pequenos braços e dirigiram-se para as suas cavernas a fim de deliberarem acerca das medidas a tomar perante a invasão dessa mancha cujos contornos alastravam. Estiveram reunidos longamente e quando chegaram a uma conclusão, embora provisória, enviaram os espias para fora das cavernas para averiguarem quais os progressos feitos pelo inimigo. Quando saíram das cavernas os espias não viram nada. Era de noite. Concluíram que o inimigo se retirara talvez para procurar reforços. Ficaram de sentinela a ver o que acontecia. Quando o sol começou de novo a surgir no horizonte recolheram às suas cavernas para prestarem as suas informações. Novamente reuniu a assembléia dos homúnculos sábios que ficaram deliberando longamente. Quando chegaram a novas conclusões enviaram os seus espias para fora das cavernas para averiguarem quais os progressos feitos pelo inimigo. Quando saíram das cavernas os espias não viram nada. Era de noite. (HATHERLY, 2006a: 173).

Nesta narrativa, a autora evidencia a tensão entre consciência, realidade e discurso: aquilo que percebemos com os cinco sentidos e racionalizamos com o intelecto não 
corresponde, necessariamente, a uma realidade objetiva (e podemos recordar aqui o conceito indiano de maya, ou ocultamento do Ser por uma sobreposição mental. É conhecida a anedota contada pelo filósofo vedantista Shankara: caminhamos numa floresta à noite, vemos no chão um rolo de corda e sentimos medo, pensando ser uma serpente. O medo ocultou a corda e projetou sobre ela a imagem mental da serpente, criando assim a ilusão) (SHANKARA, 1992: 81). O que julgamos ser real, de acordo com esta filosofia, não é algo distinto do sonho, já que nossos sentidos são limitados e a consciência humana está sujeita à confusão e ao engano. Conforme diz Fritjof Capra em seu livro O Tao da Física, “a ilusão reside meramente em nosso ponto de vista, se pensarmos que as formas e estruturas, coisas e fatos existentes em torno de nós são realidades da natureza, em vez de percebermos que são apenas conceitos oriundos de nossas mentes”. (CAPRA, 1989: 73)

De acordo com o pensamento monista védico, expresso nos Upanishads, no Vedanta-Sutra e nos comentários de Shankara, Radhakrisnan, Vivekananda e outros eruditos indianos, o universo físico é impermanente, efêmero, e se manifesta em estado de contínua mutação; logo, é uma realidade temporária, como um sonho — o que nos faz lembrar da peça de Calderón de la Barca, La vida es sueño, e ainda do Padre Manuel Bernardes, que no livro Luz e calor define o mundo como "hospital de doudos, aparência e jogo de títeres, casa cheia de fumo, inferno breve sobre a terra, ilha dos degradados” (HATHERLY, 1997, 95). Na concepção barroca, sintetiza Ana Hatherly, “a vida, o mundo real, não passam de um sonho, um sonho de que é urgente acordar” (idem), ponto de encontro entre a metafísica indiana e a mística cristã seiscentista. 
O universo físico, no sistema monista védico, é concebido como um jogo ${ }^{46}$ (lila) de Brahman, o Ser eterno, imutável, que se oculta sob o véu de maya: todas as ações humanas fazem parte deste jogo cósmico, e nós somos atores da peça divina, também simbolizada na imagem da dança mágica de Shiva Nataraja, o deus de quatro braços que cria, sustenta e aniquila os mundos. Segundo Capra, “na concepção hinduísta da natureza, todas as formas são relativas, fluidas, maya em eterna mutação, conjuradas pelo grande mago da peça divina. O mundo de maya transforma-se continuamente, uma vez que a divina lila é uma peça rítmica e dinâmica”47 (idem).

O pensamento e as formas do imaginário da cultura indiana, diga-se de passagem, não são estranhos ao repertório de Ana Hatherly, que como epígrafe ao romance $O$ Mestre escolheu um fragmento de Le Nouveau Ramayana, de Aubrey Menen, que trata justamente do tema da ilusão: “Tu m’as montré que bien des choses n'étaient qu'illusion. Mais dans ta conception du monde, y a-t-il quelque chose qui te paraît vraie?”, pergunta o herói Rama ao sábio Valmiki, que responde: “Certainement, Rama. Il y a trois choses qui sont vraies: Dieu, la folie humaine et le rire ${ }^{48, "}$ (HATHERLY, 2006b: 19)

Numa perspectiva não-teológica, podemos interpretar essa visão sobre o caráter ilusório e impermanente de todas as coisas em termos de linguagem: a realidade seria uma forma de discurso móvel, ambíguo e efêmero, assim como a mente humana e os estados de

\footnotetext{
${ }^{46}$ Como lembra Johan Huizinga, a palavra ilusão "significa literalmente 'em jogo' (de inlusio, illudere ou inludere)”. (HUIZINGA, 2007: 14) Segundo afirma o filósofo, o termo sânscrito lila pode ser traduzido também como "parecer", "imitar", "a aparência das coisas" (idem, 37). Em latim, o termo ludus tem esse mesmo duplo sentido de "jogo" e "irreal, ilusório" (idem, 41).

${ }^{47} \mathrm{O}$ mundo material era chamado metaforicamente, no século XVII, de “floresta de enganos”, em outro ponto de contato entre o pensamento barroco e o oriental.

${ }^{48}$ A questão do riso, abordado por Freud em $O$ chiste e sua relação com o inconsciente (1905), é um dos temas básicos do romance $O$ Mestre.
} 
consciência da vigília, do sonho e do sono sem sonhos. Ao representar a realidade como um sistema de signos mutável, o texto literário indica a precariedade de nossa capacidade de apreensão e produção de conhecimento, e denuncia o caráter artificial da mímese, que define a realidade a partir da aparência imediata (e enganosa) dos fenômenos.

A escrita de Ana Hatherly, guiando-se em sentido contrário ao da mímese, privilegia os jogos do imaginário, deixando explícita a sua intenção de criar um universo próprio pela palavra poética, universo lúdico e plurívoco ${ }^{49}$. Sua arte fabulatória aproximase da lógica de construção e desenvolvimento da narrativa no sonho, que podemos considerar um tipo de discurso que transcende fronteiras de tempo, espaço e sujeito, ao mesmo tempo em que integra sons, imagens e idéias numa forma de “cinema mental”. O modo como o sonho organiza cenas e seqüências pode ser comparado à linguagem cinematográfica, como se o olho fosse uma câmera e a mente um laboratório de edição e sala para a projeção de imagens.

O sonho é um território livre para a invenção “fílmica”, pois todos os fenômenos que observamos na experiência cotidiana podem ali ser alterados quanto à forma, sentido e função, mudando não apenas a sua natureza mas também a sua relação com os demais fenômenos. A liberdade criativa oferecida pelo estado do sonho, que não é regido pelos mecanismos de controle de nossa racionalidade cotidiana, já encantou escritores como Samuel Taylor Coleridge, William Blake, Gerard de Nerval, Antonin Artaud, Lautréamont,

\footnotetext{
${ }^{49}$ Affonso Ávila escreveu, a esse respeito, em seu livro O lúdico e as projeções do mundo barroco: "Sabe-se que a linguagem literária, ainda quando tendente à enfatização denotativa, a exemplo da prosa de ficção, tem sempre por objeto aquela co-realidade imaginada, criada, estruturada sobre a palavra, o objeto novo e autônomo contraposto pelo escritor como uma parábola à realidade fatual e linear. Essa autonomia pretendida da obra só se concretizará, porém, na medida em que o autor, imprimindo simultaneamente a sua escritura força de convicção semântica e direção de polaridade estética, for capaz de suscitar o estranhamento, isto é, de quebrar, com a novidade de sua criação, uma noção de conhecimento ou representação do mundo já convencionalizada pelo uso rotineiro da língua (vem a propósito a observação de Roland Barthes de que, para o escritor, 'escrever significa estremecer o sentido do mundo)”. (ÁVILA, 1994: 78)
} 
Jorge Luis Borges, André Breton e os surrealistas franceses, que na década de 1920 fizeram experiências que valorizavam a ação do inconsciente na criação da obra de arte, como a escrita automática e o jogo coletivo do “cadáver esquisito”.

O caráter transformador do sonho, que subverte o sentido e a representação das coisas e a própria enunciação do discurso, fascinou também Ana Hatherly, que se deixou influenciar pelos procedimentos da escritura onírica na composição das Tisanas — por exemplo, no fragmento n. 390: “Acordo no meio da noite perturbada por um sonho extravagante: estou numa casa onde se passam coisas estranhíssimas. Numa das salas que percorro um cão recita os Salmos de David.” (HATHERLY: 2006a, 143) e sobretudo de Anacrusa, que analisaremos no tópico seguinte.

\section{6 - Sonho, mito e criação poética}

“Ao anotar durante cerca de vinte anos todos os sonhos que tive”, escreve Ana Hatherly no prefácio de Anacrusa, “obedeci a um plano de observação bidimensional: por um lado, concentrando-me no modo (variável) como o sonho era recordado, e por outro, no modo (o menos variável possível) como o sonho era por fim fixado no texto” (HATHERLY, 1983b: 5). De modo diverso ao da construção ficcional, no relato de um sonho, o autor que deseje expressa-lo com exatidão “está moralmente obrigado a apenas traduzir, verter para a escrita uma experiência que recebeu já completa e que não deve transformar, a não ser aquele mínimo a que a comunicação obriga” (idem). Essa relação tradutória entre sonho e escritura, imaginário e memória, é o cerne do diário noturno que a autora escreveu entre 1959 e 1977, e que em sua configuração impressa reuniu relatos de 68 sonhos, escritos na forma de pequenos contos ou poemas em prosa, fragmentários e concisos, que indicam afinidades estilísticas com as Tisanas, como a brevidade, o humor e a aproximação com a 
pintura e as artes visuais — e lembremos que na Tisana 245 a autora diz: "Um colega que eu mal conheço descobre um velho exemplar do meu livro de sonhos” (HATHERLY, 2006a: 103).

O sonho é uma experiência visual por excelência, como o cinema ou o teatro; porém, as imagens se desenvolvem de forma ambígua, contraditória e em seqüência nãolinear na mente do sonhador, que é ao mesmo tempo “o teatro, os atores e a platéia” e ainda “o autor da fábula que está vendo”, segundo o escritor argentino Jorge Luis Borges, parafraseando Joseph Addison (BORGES, 1985: 5).

Conforme E. M. de Melo e Castro, no sonho, experiência involuntária e inconsciente, se manifestam “dimensões, cores, tatos, gostos e cheiros diferentes e de uma qualidade diferente” (HATHERLY, 1983b: 61), ou seja, percepções não-verbais que não podem ser recriadas no código escrito. A tradução do discurso onírico para o textual é dificultada também pelo fato de que o relato dos sonhos é realizado no estado da vigília, registrando assim um "resíduo aparente da atividade mental e imagística tida durante o estado de sono e, mesmo assim, só daquela parte que conseguimos deter na memória consciente”. (idem, 60). Deste modo, na avaliação do poeta português, o relato de um sonho seria algo diverso do próprio sonho, um outro tipo de texto, que obedece à lógica verbal. “A questão fulcral parece-me ser a diferença qualitativa entre esses dois códigos que referi, o do sonho e o da escrita”, sintetiza Melo e Castro (idem), que avalia os relatos de Anacrusa (usando o jargão poundiano) como textos que "tendem para o máximo da qualidade do código da escrita, através de uma síntese que os torna linguagem sobrecarregada de significados: são poemas” (idem, 61).

Qualquer que seja o grau de correspondência ou verossimilhança entre sonho e relato, o que nos importa aqui não é a possibilidade de uma tradução intersemiótica, e sim 
verificarmos a contaminação da escrita pelos elementos narrativos do sonho, considerado por Borges “o mais antigo e o não menos complexo dos gêneros literários” (BORGES, 1985: 5). O cruzamento entre os dois códigos está indicado já no título do livro: a palavra anacrusa (do grego aná, “para cima”, + krousis, “ação de bater”), além do sentido técnico que possui na música erudita — refere-se às notas de uma melodia que precedem numa pauta o início de um ritmo — pode ser lida, de maneira neológica, como “Ana cruza” a fronteira entre real e irreal, sonho e escritura, pensamento racional e mitologia.

Os dois textos escolhidos como epígrafes do livro são significativos, dentro desta linha de raciocínio: o primeiro é uma transcrição de antiga história tradicional dos índios Uitoto, da Colômbia, a respeito da criação do mundo, e o segundo uma definição psicanalítica do sonho por C. G. Jung, extraída do livro O homem à descoberta da sua alma. Na primeira epígrafe, a visão mítica dos índios colombianos é similar à doutrina sobre maya, a que já nos referimos. Diz o relato Uitoto:

No princípio, o verbo gerou o pai. Havia uma imagem-sonho, mais nada; o pai aflorou uma ilusão, algo de misterioso. Nada existia. Devido ao efeito dum sonho, o nosso pai (que é ele mesmo um sonho, ou que está a ter um sonho) deparou com o reflexo do seu corpo e ficou muito tempo a cogitar, tendo caído em profunda reflexão.

Nada existia, nem sequer um objeto que amparasse a visão: o nosso pai entreteceu a idéia com a teia dum sonho e guardou-a com a ajuda do seu corpo. Ficou à escuta, para atingir o fundo da aparência, mas nada havia. Nada existia.

E de novo o pai se pôs a perscrutar o fundo do mistério. Amarrou a ilusão vã ao fio do sonho e imprimiu-lhe a substância mágica. Conservou o fio na mão com a ajuda do seu sonho - como um punhado de penugem, de algodão. Então atingiu o chão firme da aparência, saltou-lhe várias vezes em cima e aí, finalmente, pousou na sua sonhada terra.

(Mito dos índios Uitoto, da Colômbia, segundo a versão de David Coxhead e Susan Hiller. Traduzido por Alberto Pimenta da versão alemã de Jochen Schatte, in: “Traumes”, Frankfurt am Main, 1976, Umschau Verlag.) (idem, 3)

Nesta “cena da origem” ameríndia, a palavra é o princípio da criação (assim como nas mitopoéticas hindu, cristã, maia e de diversas culturas afro-asiáticas) e o sonho é o 
recurso mágico que dá substância e forma ao mundo, constituindo também a essência misteriosa do próprio criador — e podemos recordar aqui a imagem purânica do deus Vishnu adormecido sobre a gigantesca serpente Sesha; de seu umbigo nasce uma flor de lótus, da qual surge o deus Brahma, que cria os mundos pela recitação dos Vedas. Quando se passam as quatro idades cíclicas de uma kalpa, ou éon, Vishnu acorda de seu sonho e a flor de lótus, Brahma e o universo recolhem-se para dentro de seu umbigo, de volta ao vazio anterior à criação, num eterno jogo de criação, mutação e dissolução de formas.

A relação entre arquétipo, sonho e mito já foi abordada por estudiosos como Mircea Eliade, C. G. Jung e Joseph Campbell, para quem “o sonho é o mito privado. O mito é o sonho coletivo” (ASSUNÇÃO, 2002: 11), mas o que nos interessa sublinhar nesta antiga história tradicional é a noção da palavra como fundadora do discurso, da consciência e, portanto, da realidade (que não se distingue do sonho, na visada mitopoética, por ser mutável e impermanente). Conforme diz o crítico Fernando J. B. Martinho, a escrita de Ana Hatherly não se segue à “compreensão e à apreensão da realidade”, não visa “duplicar” ou “reproduzir” o mundo, mas antes “inventar, criar, ‘produzir’ outros mundos, acrescentar outros mundos ao mundo ('o que o mundo não tem / o que o mundo não diz / o que o mundo não é’)”. (HATHERLY, 2004: 49-50) O trabalho do poeta, diz o crítico, é de “invenção ou de reinvenção”, em vez de fabricar simulacros de um presumível “real”; ou, conforme diz Martinho, nesta mesma passagem, citando versos de Ana Hatherly, o poeta “olha o mundo / e reinventa-o/ no seu jardim feito de tinta” (idem).

A escrita, portanto, tem um caráter de ação fundadora, ela é o próprio herói mítico, autor da civilização (e lembremos aqui do deus nórdico Odin, inventor do alfabeto das runas; do egípcio Thot, chamado de Hermes pelos gregos, a quem é atribuída a criação dos hieróglifos; e ainda da tradição cabalista, segundo a qual o universo foi criado a partir das 
22 letras do alfabeto hebraico ${ }^{50}$ ). Ao forjar o mundo pela linguagem, o escritor revela ou recria, ao mesmo tempo, a sua própria subjetividade, o seu próprio eu: o artífice se define pela sua ação, e podemos citar aqui a definição de Marx, para quem “A minha propriedade é a forma, ela é a minha individualidade espiritual. Le style, c'est l'homme.” (MARX, Karl, e ENGELS, Frederich, 1980: 31). Ana Hatherly aborda a questão do seguinte modo, no prefácio de Anacrusa:

Se é verdade que, mais ou menos deliberadamente, todo o escritor participa na criação de mitos através da (re)invenção da linguagem que constantemente pratica, entre esses mitos deverá incluir-se o da (re)criação do próprio eu do escritor, necessariamente imbuído de concepções fáusticas e chamadas ao Golem.

O papel desempenhado pelos sonhos na construção desse eu do escritor pode ser notável se para ele o sonho for mais uma forma de conhecimento, mais uma forma de registro da experiência e portanto mais um campo de experimentação. (...)

Ao considerar os aspectos de transferência e de metamorfose que apesar de tudo se produziram, a minha experiência assemelhou-se bastante a uma reflexão sobre as bases míticas da escrita criadora e seu processo de manifestação. (...)

Por fim, no seu conjunto, este volume contém uma matéria que chama a atenção para os múltiplos planos da experiência da escrita, apreensíveis através da leitura. Cifrados como são, estes textos propõem algumas reflexões sobre os mecanismos da captação e comunicação da experiência mítica de que participa a criação do texto. (HATHERLY, 1982: 5-6)

Nesta passagem, a autora coloca em evidência suas estratégias de escrita, relacionando poética, mitologia e experimentação. Se nas Tisanas havia a proposta de efetuar uma "pesquisa da realidade" pelo estudo das estruturas da narrativa e da linguagem, bem como de "suas correspondentes estruturas lógica e psicológica" (HATHERLY, 2006a: 13), em Anacrusa a proposta é tecer reflexões "sobre os mecanismos da criação e comunicação da experiência mítica de que participa a criação do texto” (HATHERLY, 1982:

\footnotetext{
${ }^{50}$ Podemos recordar também o prólogo do Evangelho segundo São João: "No princípio era o Verbo, e o Verbo estava com Deus, e o Verbo Era Deus”.
} 
7). Essa jornada, como adverte a autora, nada tem em comum com as teorias de Freud, Jung e seus discípulos nem com as práticas surrealistas a elas relacionadas.

"A esse conhecimento não posso furtar-me totalmente, mas o que posso, e isso mesmo tentei fazer, é não aplicar essas teorias, procurando situar minha pesquisa fora do seu âmbito” (idem, 6). Apesar desta advertência, e talvez para explicitar o seu afastamento de qualquer leitura psicanalítica, a autora reproduz, como segunda epígrafe de Anacrusa, logo após o relato dos índios Uitoto, uma passagem do psicanalista suíço C. G. Jung, para quem “O sonho é uma criação psíquica que, em contraste com os dados habituais da consciência, se situa pelo seu aspecto, pela sua natureza e pelo seu sentido, à margem do desenvolvimento contínuo dos fatos conscientes” (idem, 3).

Enquanto a primeira epígrafe é um relato cosmogônico, em que o sonho é uma força mágica capaz de criar o universo, na segunda epígrafe o sonho é um fenômeno psíquico que pode ser conceituado e analisado racionalmente. A polarização entre estas duas inserções intertextuais em Anacrusa é explicitada pela autora: "A diferença entre a atitude dos antigos e a dos nossos contemporâneos a respeito do sonho (...) reside neste ponto essencial: enquanto hoje queremos explicar o sonho, os antigos quiseram interpretálo" (idem, 6). No primeiro caso, diz a autora, "estamos perante uma atitude de desmitificação; no segundo caso, estamos perante uma atitude de re-mitificação" (idem).

O sacerdote ou xamã das culturas indígenas, ao comunicar pela palavra um sonho concentrado de símbolos, criava ou participava de um mito, por vezes profético, que era compartilhado com a sua aldeia, como ainda hoje acontece em algumas comunidades. É com este processo ancestral que Ana Hatherly dialoga, em sua reflexão sobre as "bases 
míticas da escrita criadora e seu processo de manifestação” (idem), apresentando seus mitos privados à comunidade dos leitores ${ }^{51}$.

\section{7 - Leitura comparada: Anacrusa e Tisanas}

O primeiro sonho anotado em Anacrusa, datado de 05/03/1959, refere-se a uma “estranha criatura, de dimensões ciclópicas”, com a cabeça de um velho, “de grande cabeleira e barbas, uma espécie de Adamastor”, que diz à sonhadora uma frase ao mesmo tempo reveladora e enigmática: “a vida que vives agora é apenas uma das tuas muitas encarnações; numa outra vida foste outra coisa e na tua primeira encarnação o teu nome foi TAHELDA NIMBO (Ele pronunciou o H aspirado)” (idem, 11).

Este pequeno relato, de apenas oito linhas, traz vários elementos típicos da gramática dos sonhos, como a aglutinação híbrida de símbolos, conceitos e imagens de diferentes culturas (o gigante Adamastor, personagem mitológico citado por Camões no Canto V, versos 37 a 60, d’Os Lusíadas; a doutrina do renascimento cíclico, que integra a filosofia religiosa hindu e budista); a “edição de imagens”, como o recorte do corpo do velho, de quem ela só vê a cabeça; a aplicação da hipérbole, que faz esta cabeça ter “dimensões ciclópicas” (outro belo exemplo desse recurso é a “planta que parecia uma floresta em miniatura”, citada no sonho de 22/07/1962); e o enigma proposto para decifração, como o nome-emblema grafado em letras maiúsculas TAHELDA NIMBO.

A citação de Adamastor é significativa, pela pluralidade de rotas interpretativas que oferece ao leitor: é a inclusão de um mito dentro do sonho (mito transformado pela imaginação de quem sonha); é uma referência literária, extraída do poema mais importante da literatura portuguesa; é a tradução simbólica de outras traduções, já que Camões buscou

\footnotetext{
51 “O mito como a poesia se situam dentro da esfera lúdica.” (HUIZINGA: 2007, 144)
} 
o seu personagem nas literaturas grega e latina, ou mais especificamente em Homero e Horácio; por fim, é a incorporação de um personagem que representa o princípio da metamorfose, já que foi convertido por Zeus no Cabo das Tormentas como castigo por seu intento de violar a nereida Tétis.

No poema de Camões, o gigante é avistado com temeridade por Vasco da Gama, simbolizando as ciladas e perigos que surgem em meio à jornada épica. No sonho de Ana Hatherly, ele surge não como prenúncio de desastre ou ameaça, mas como figura profética, à maneira da pitonisa do oráculo de Delfos, que deixa uma mensagem misteriosa para a decifração daquela que sonha (o nome TAHELDA NIMBO, que pode ser anagrama, palavras em língua remota, arcaica ou mera construção sonora, como a linguagem zaúm de Khlébnikov). A esse respeito, convém citar que o recurso do enigma apresentado na forma de emblema (texto que acompanha uma imagem, típico do barroco) aparece em outros sonhos do livro, como o de 10/11/1969 (“A terrífica carne do útero”).

A transformação de referências mitológicas acontece também no sonho de 19/06/61, em que outro gigante, agora Polifemo ${ }^{52}$, aparece encarnado de forma irônica na imagem de um veículo híbrido, “misto de tank de guerra e camião de gasolina, tendo por única janela uma abertura circular à frente. Digo: claro, um só olho de Polifemo” (idem, 16). Esta imagem concentrada carrega uma série de antíteses ou tensões entre o passado e o presente, a referência erudita e a prosaica, a paisagem natural e a urbana, a mitologia e a técnica. A personificação da máquina no retrato caricatural de um tanque / caminhão / Polifemo remete ainda à "lógica da metamorfose”, a que já nos referimos neste trabalho,

\footnotetext{
52 A citação irônica ou paródica de personagens mitológicos de diferentes épocas e culturas é um recurso utilizado por Ana Hatherly em diversas obras; no romance $O$ Mestre, por exemplo, são citados Anúbis, Diana, Aksobya, Actéon, o Minotauro, entre outros.
} 
que a autora aplicou nas Tisanas, especialmente em seu “metaforismo alegórico” (HOCKE, 2005: 246) que se assemelha à pintura de Arcimboldo. O caráter monstruoso dessa imagem, por sua vez, recorda certas figuras da pintura, do teatro e da literatura maneiristas, tema estudado por Gustav Hocke em seu livro O mundo como labirinto:

Os monstros eram desarmonias possantes e tumultuadores discordantes que, por volta de 1600, se destacavam no teatro, como, por exemplo, no King Lear, de Shakespeare. (...) O elemento paranóico do Maneirismo de todos os tempos procura no monstro e no monstruoso uma 'encarnação' demasiadamente grande da deformação. Encontra-se aqui a influência de algumas narrações fantásticas de lendas hindus, da literatura hebraica e de suas descrições sobre os demônios e ainda os livros infantis. (...) O monstro é encarado como a antítese do 'bom gosto', criação da natureza mágica (HOCKE, 2005: 145-46).

No sonho de 25/12/1969, Ana Hatherly refere-se a uma estranha mulher que ostenta

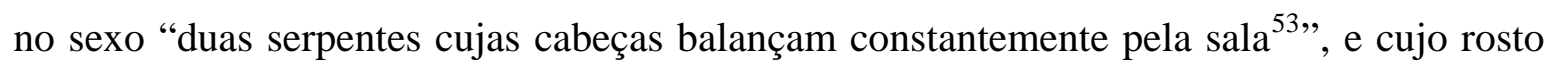
“é um misto de javali e galinha” (idem, 25); no sonho de 24/12/1969, por sua vez, ela diz:

Algumas crianças encantadas com as minhas TISANAS oferecem-me presentes, entre eles um ramo, que é uma espécie de cacho de tangerinas, constituído de tal forma que o conjunto forma 'uma fruta perfeita'. Compreendi então que a minha obra só poderia ser amada pelas crianças, porque estão sempre naturalmente mais avançadas (idem, 24-25).

Este sonho é significativo por introduzir, além da imagem arcimboldesca do cacho de tangerinas, uma referência direta às Tisanas, com a qual há numerosas afinidades estilísticas. A geografia imaginária de ambos os livros é rica na citação de países exóticos, como a Pérsia, o Egito, a China e o Marrocos, além da descrição de cidades fantásticas, que derivam talvez das leituras dos relatos de navegadores europeus como Marco Polo, Cabeza de Vaca ou Hernán Cortez.

\footnotetext{
53 Estas imagens recordam o estilo grotesco do maneirismo, estudado por Gustav Hocke em seu livro já citado. O autor informa que, “nos afrescos e nos 'grotescos' dos aposentos dos papas, podem ser vistas libélulas com rostos femininos, homens com pernas em forma de flor, mulheres com seios que descem até os quadris. Podia-se ver ainda um corcunda com um pênis descomunal, um fauno que mostrava o mesmo membro para uma fêmea em tempo de cio. (...) Nota-se um aproveitamento acrobático da perspectiva e uma terrível negação das leis do espaço. (...) Outros seres são, em parte, vegetais, em parte, de terra, e em parte, de agia, como as criações antidiluvianas de Max Ernst”. (HOCKE, 2005: 115)
} 
O sonho de 06/11/1969, por exemplo, fala de uma metrópole-necrotério onde “o ar é tão espesso que não se vê a paisagem e quase não se pode respirar. Tudo tem uma cor doirado-cinza e o ar é uma espécie desconhecida de pó de cimento” (idem, 23). Em outros relatos, encontramos invenções inúteis ou inusitadas como o aspirador de pó que "não só não fazia barulho nenhum como até tocava uma música lindíssima quando estava a trabalhar" (idem, 30) ou a "pálpebra eletrônica”, mecanismo concebido para "resolver o problema do encadeamento pelos faróis quando dois automóveis se cruzam de noite na estrada usando os máximos” (idem, 53).

Em Anacrusa, assim como nas Tisanas, encontramos a representação antropomórfica de animais ou seres inanimados, como os caranguejos que dançam entrelaçados no sonho de 03/1964; a reinvenção caprichosa da natureza, como o rato cor de vinho do sonho de 29/12/69 ou a mulher de "quatro seios" do sonho de 22/06/61; a criação de monstros ou feras insólitas, como a criatura de cabeça "absolutamente anormal”, sem orelhas, que "mesmo assim tem algo de humano, apesar do seu corpo de cavalo, com larga garupa e patas pesadas", descrita no sonho de 22/03/1973 (idem, 34), ou o "animal selvagem e algo absurdo, misto de foca, castor e talvez javali, uma raça que ninguém conhece”, do sonho de 02/12/1973. Encontramos ainda referências a escritores célebres, como Gertrude Stein, T. S. Eliot, Fernando Pessoa e John Keats, a quem a narradora dos sonhos faz visitas apócrifas; e uma farta presença de animais, pássaros e insetos, que não raro assumem atitudes ou características humanas, como o "pequeno gato branco que começa a falar” do sonho de 12/06/1976.

O paralelo que podemos estabelecer entre as Tisanas e Anacrusa, porém, não é apenas temático, mas também estrutural e estilístico: os dois livros são construídos como seqüências de pequenos relatos em prosa poética, identificados por números ou datas; os 
textos em ambos os volumes são híbridos, misturando diferentes formas narrativas, como a parábola, a fábula ou o koan (“é preciso deixar espaço para o silêncio”, diz o sonho de 28/05/1965); e podemos reconhecer, nessas breves histórias paradoxais, o uso freqüente da alegoria e da retórica da pintura.

O sonho de 21/05/1959, por exemplo, um dos mais estranhos do volume, inicia com a descrição de "um mapa em relevo que mostrava o caminho que o homem tinha percorrido e tinha ainda de percorrer para atingir a verdade” (idem, 11), tema que se relaciona, como veremos no tópico seguinte, com o romance $O$ Mestre. Este mapa é descrito como "uma grande região montanhosa, enevoada, onde de quando em quando se viam três luzeiros”, que são identificados, por uma voz misteriosa, pelos nomes de São Tomás de Aquino "para dar consistência à terra” — e Santo Antônio — “cujo fogo dissolve o gelo glaciar” — (idem, 11-12); o terceiro luzeiro não é identificado, permanecendo anônimo. Este sonho alegórico é interpretado de diferentes formas nos comentários de autores convidados que Ana Hatherly incluiu no final do livro, numa curiosa forma de dialogismo e intertextualidade (alguns comentaristas não apenas escrevem a respeito dos sonhos da autora, mas ainda contam os seus próprios sonhos, inventados ou verídicos, ou criam poemas em prosa a partir dos relatos de Ana Hatherly).

Alberto Pimenta, falando sobre a imagem dos três luzeiros, identifica uma representação da trindade cristã e ainda uma possível aproximação dialógica com o Sermão de Santo Antônio, do Padre Antônio Vieira, que diz: "Eu cuidava que o Sol, por ser fonte da luz, era Cristo: e que a candeia por ser luz participada, era Antônio. Mas não é assim. A candeia é Cristo, o Sol é Antônio" (idem, 49-50). Esta interpretação é curiosa porque Pimenta compara o sonho a um texto literário do século XVII, em que vai buscar a origem 
dos símbolos apresentados no relato onírico - uma outra forma de dizer, talvez, que os sonhos também são literatura, e portanto dialogam com a tradição literária.

Já frei Adelino Pereira, numa leitura teológica do sonho, observa que "A luz é símbolo de Deus. Deus significa, etimologicamente, o luminoso. Os luzeiros são reflexos de Deus, são por isso mesmo santos” (idem, 45). Após tecer considerações sobre os dois luzeiros identificados com Santo Antônio e São Tomás, Pereira especula que o terceiro lume, não nomeado, seria São Francisco de Assis, “o homem que faz sendo e é fazendo, o homem que mais se cristificou, o homem que vai na crista da onda humana em sua mais puríssima realização” (idem, 46). Nesta leitura, Pereira vai buscar não o intertexto literário, mas a presença inconsciente, no sonho, de símbolos do imaginário cristão, interpretando-o de acordo com uma visada metafísica, de alguém que acredita no propósito da salvação. O mesmo sonho, antes lido como texto literário, é agora visto como representação mística.

Estabelecida a relação entre as Tisanas e Anacrusa, concluiremos este tópico abordando brevemente algumas diferenças temáticas entre os dois livros. Em Anacrusa, são notáveis as cenas de relações sexuais inusitadas com máquinas, animais ou seres inanimados. No sonho de 04/01/1971, a autora diz:

Sonhei que fazia amor com um automóvel branco, um Citroen DS. Dois homens conduziam esse carro, desafiando-me a ficar em cima da carrosserie, muito lisa e escorregadia, enquanto guiavam o carro a grande velocidade. (...) Vestia roupas curtas, transparentes, fluentes sobre o corpo nu. Voava e ria com a mais pura alegria, tocando por vezes no carro, até que por fim me achei de pé no guarda-lamas traseiro. Com os braços e as pernas agarrados ao carro, lentamente senti o meu corpo cobrir-se duma espécie de inúmeras bocas que se colavam à carrosserie como ventosas de polvo, mas com a forma de bocas humanas. E eram muitas, muitas. Com a velocidade incrível sentia o êxtase (idem, 28-29).

Já no sonho de 12/05/1961, temos uma situação de zoofilia: “Estou numa praia. Há muita gente. O sonho é confuso. Um cão preto enorme, muito maior que o maior cão que 
jamais vi, agarra o meu braço esquerdo com as patas, apaixonadamente” (idem, 15). Por fim, no sonho de 10/11/1969 temos uma complexa alegoria sexual encenada no elemento água, símbolo do feminino — todos os personagens do sonho são mulheres —, em que "moluscos ostentando enormes antenas cor de amêijoa" e patos de "olhos brilhantes e bicos amarelos” (idem, 24) representam atributos de Eros.

A carnavalização alegórica do erotismo, que em sua imagética marinha se aproxima do Anatômico Jocoso de Frei Lucas de Santa Catarina, está presente também nas representações da morte, talvez o tema mais recorrente nos sonhos de Anacrusa, onde há numerosas referências a cemitérios, velórios, enterros e caixões, não faltando inclusive o matrimônio com um morto, no sonho de 10/11/1973: "Estou numa igreja muito sombria, cheia de gente vestida de preto. Vai realizar-se o meu casamento, mas na verdade trata-se de confirmar o meu casamento com um morto (...), cuja ligação comigo preciso sacralizar”. (idem, 38)

A dramatização do princípio da vida e de sua próxima extinção é um dos temas caros ao barroco, especialmente da pintura barroca, como no quadro El sueño del caballero, de Antônio de Pereda (século XVII), em que um anjo aponta para uma mesa onde se amontoam objetos díspares como máscaras, ornamentos, flores, livros, moedas e crânios, a simbolizar talvez nossa passagem pelo mundo, efêmera como um sonho. O anjo traz em suas mãos um emblema, com a inscrição “O eterno fere sem cessar, voa rápido e mata” (HATHERLY, 1997: 103). Conforme diz Ana Hatherly, em seu ensaio sobre a representação do tempo, incluído em O ladrão cristalino,

A morte esconde-se sob a vida, está implícita na vida. O tempo é aquilo que a revela, o que permite ver o seu fundo de ruína. Neste contexto, como em todo o contexto barroco 
em que se medita sobre o tempo, a função da arte não é explicar mas sim desnudar-se: dar a ver ${ }^{54}$. (idem, 104).

A metáfora do sonho, dentro desse território ético e metafísico, é basilar porque indica a brevidade da vida humana no teatro provisório em que atuamos:

Assim, em virtude da ação do tempo, não se pode deixar de verificar que todo o estável é ilusório, mas é precisamente essa verificação do transitório o que nos vai remeter para o transcendente. E dada a promessa de salvação, a morte não é mais do que a vitória do eterno sobre o efêmero. (idem).

Porém, o que significa a constatação da proximidade da morte quando não temos esperança na salvação? Anacrusa atualiza o drama barroco inserindo-o na idade contemporânea (que é, segundo ela, a “idade da escrita”), uma era da velocidade, da mescla, do ruído e do tumulto, em que só nos resta, talvez, a liberdade de interpretarmos estes sinais.

\section{8 - A poética do jogo}

A palavra jogo vem do latim jocu, que significa “gracejo” ou “zombaria”, conforme a definição do dicionário (HOLLANDA, 1986: 990). O termo latino, por sua vez, é posterior a ludus, que abrangia “os jogos infantis, a recreação, as competições, as representações litúrgicas e teatrais e os jogos de azar,” segundo Johan Huizinga, em seu livro Homo ludens - O jogo como elemento da cultura (HUIZINGA: 2007, 41). A palavra teria ainda o sentido de “'simular' ou de 'tomar o aspecto de’. Os compostos alludo, colludo, illudo apontam todos na direção do irreal, do ilusório” (idem). A idéia de ilusão, aqui, não indica falsidade ou inexistência, mas brincadeira, fingimento, imaginação. Conforme Huizinga, “O jogo se

\footnotetext{
${ }^{54} \mathrm{O}$ tema da morte é recorrente também na poesia em versos de Ana Hatherly, como na composição Arte e morte em Veneza, que integra o volume A Idade da escrita: “A morte é um estado realmente sórdido / por isso a cobrimos de toda a fantasia / inventando mitos de passagem. / (...) / O ar que falta: / o barroco fala da morte / do seu teatro. / O inferno é italiano.” (HATHERLY, 2005: 69)
} 
baseia na manipulação de certas imagens, numa certa ‘imaginação’ da realidade (ou seja, a transformação desta em imagens)”. (idem, 7).

A relação entre esse conceito e o da criação poética, e em especial com a metáfora, é evidente: "Por detrás de toda expressão abstrata se oculta uma metáfora, e toda metáfora é um jogo de palavras. Assim, ao dar expressão à vida, o homem cria um outro mundo, um mundo poético, ao lado da natureza” (idem). Esse universo lúdico, similar ao sonho e ao mito, em que "há um espírito fantasista que joga no extremo limite entre a brincadeira e a seriedade” (idem), é no entanto um sistema organizado, uma estrutura, em que há regras claras e precisas para o seu funcionamento.

A primeira definição de jogo, no verbete de dicionário, diz justamente o seguinte: "Atividade física ou mental organizada por um sistema de regras que definem perda ou ganho” (HOLLANDA, 1986: 990). A existência de regras é essencial para o funcionamento do jogo, pois elas “determinam aquilo que 'vale' dentro do mundo temporário por ele circunscrito. As regras de todos os jogos são absolutas e não permitem discussão” (HUIZINGA, 2005: 14) ${ }^{55}$. Assim, no jogo de xadrez, o bispo sempre se moverá nas diagonais, e o cavalo avançará na forma de um "L” — não podem intercambiar funções; no jogo de cartas, é atribuído um valor a cada carta, e a cada seqüência de naipes dispostos na mesa. O jogo é uma estrutura móvel e combinatória em que todas as peças ou movimentos dos jogadores têm valor, isoladamente e em conjunto. Por isso mesmo, reina no universo do jogo “uma ordem específica e absoluta. (...) Ele cria ordem e é ordem. Introduz na confusão da vida e na imperfeição do mundo uma perfeição temporária e limitada, exige

\footnotetext{
${ }^{55}$ Por esse motivo, segundo Huizinga, o "desmancha-prazeres” que não respeita as regras é expulso, pois ele "denuncia o caráter relativo e frágil desse mundo no qual, temporariamente, se havia encerrado com os outros” e "priva o jogo da ilusão" (HUIZINGA, 2007: 14)
} 
uma ordem suprema e absoluta” (HUIZINGA, 2007: 13), afirmação que podemos comparar a outra definição apresentada no dicionário no verbete dedicado ao jogo: “conjugação harmoniosa de peças mecânicas com o fim de movimentar um maquinismo” (HOLLANDA, 1986: 990).

A idéia do jogo como um sistema com regras específicas é muito próxima aos conceitos e procedimentos da vanguarda relativos à estrutura da obra poética ${ }^{56}$, e Huizinga observa que devido à "afinidade profunda entre a ordem e o jogo”, este último estaria, “em larga medida, ligado ao domínio da estética” (HUIZINGA, 2007: 13). E acrescenta: “Há nele uma tendência para o belo. Talvez este esforço estético seja idêntico àquele impulso de criar formas ordenadas que penetra o jogo em todos os seus aspectos” (idem).

A afinidade entre a poesia e o jogo se manifesta "na própria estrutura da imaginação criadora. Na elaboração de uma frase poética, no desenvolvimento de um tema, na expressão de um estado de espírito há sempre a intervenção de um elemento lúdico” (idem, 147-148). Esta intervenção pode ocorrer “seja no mito ou na lírica, no drama ou na epopéia, nas lendas de um passado remoto ou num romance moderno”, pois “a finalidade do escritor, consciente ou inconsciente, é criar uma tensão que 'encante' o leitor e o mantenha ‘enfeitiçado’” (idem). Podemos verificar a manifestação do espírito lúdico na poesia, segundo Huizinga, na “ordenação rítmica ou simétrica da linguagem, a acentuação

\footnotetext{
${ }^{56}$ Os poetas franceses do grupo Oulipo, por exemplo, propõem determinadas regras para a composição de seus poemas, como a exclusão de palavras que tenham certa vogal ou a criação de poemas com rigorosamente nove estrofes (regra que Roubaud adotou no livro Algo: preto), entre outros jogos verbais que se relacionam com a matemática e técnicas combinatórias. Sobre o Oulipo, aliás, escreve Ana Hatherly em A Experiência do Prodígio: "Consideremos, porém, o caso flagrante do que modernamente os experimentadores do grupo literário francês OULIPO designaram por poesia factorial, baseado nos princípios das Artes Combinatórias barrocas, segundo as quais se pode praticar em determinadas circunstâncias uma série de permutações considerável, a partir dum número limitado de elementos”. (HATHERLY, 1983: 101) É evidente também a relação com as regras da obra aberta, e com os programas do experimentalismo português, como o de Leonorana.
} 
eficaz pela rima ou pela assonância, o disfarce deliberado do sentido, a construção sutil e artificial das frases” (idem, 147). Affonso Ávila, em concordância com Huizinga, considera que "tais recursos de adensamento da expressão, manipulados pela habilidade técnica do escritor, infletem não raro para a livre associação conotativa, inscrevendo-se com isso a linguagem numa faixa de extrema abertura para o jogo” (ÁVILA, 1994: 79).

Uma forma de manifestação lúdica na poesia apontada por Huizinga é a construção de enigmas: “O que a linguagem poética faz é essencialmente jogar com as palavras. Ordena-as de maneira harmoniosa, e injeta mistério em cada uma delas, de modo tal que cada imagem passa a encerrar a solução de um enigma” (idem, 149).

Essa forma poética está presente nos aforismos filosóficos de Heráclito, nos hinos do Rig-Veda, nos poemas sapienciais do Tao Te King, nos koans zen-budistas, nas metáforas do tipo kenning ${ }^{57}$, utilizadas na poesia escandinava (por exemplo, “água da espada” para designar o sangue; “tempestade de espadas”, para dizer batalha, ou "alimento de corvos” para cadáver), no trobar clus dos trovadores provençais, como Arnaut Daniel, nas parábolas bíblicas e na poesia do barroco português, estudada por Ana Hatherly em livros como A Experiência do Prodígio e A Casa das Musas. Nesta última obra, encontramos a seguinte definição de enigma, formulada pela autora portuguesa: “O enigma é uma das formas poéticas então correntes que ilustram claramente como o prazer intelectual se podia identificar com o prazer do jogo, entendido como uma derivação do prazer de saber, do prazer de penetrar o mistério” (HATHERLY, 1995a: 153).

\footnotetext{
${ }^{57}$ No livro História da Eternidade, Jorge Luís Borges escreve que "uma das aberrações mais frias que as histórias literárias registram são as menções enigmáticas ou kenningar da poesia da Islândia. Propagaram-se até o ano 100, época em que os thulir ou rapsodos repetidores anônimos foram destituídos pelos skald, poetas de intenção pessoal. (...) Bastante numerosas, permitiam salvar as dificuldades de uma métrica rígida, que exigia muita aliteração e rima interna. (...) O caráter funcional predomina nas kenningar. Definem os objetos menos por sua figura que por seu uso”. (BORGES, 1982: 35-38)”
} 
Na composição poética enigmática, que corresponde ao sentido do jogo como “brincadeira, passatempo, divertimento” (HOLLANDA, 1986: 990) e ainda à fórmula horaciana de prodesse et dilectare, temos uma origem mais profunda, como relata Ana Hatherly: uma origem "no oculto, no encoberto que se furta ao fácil acesso”, sendo por isso mesmo “um aliciante para o gosto da época, nutrido pelos mistérios da Fé e da Natureza”, num tempo em que, na cultura européia, “a ciência está grandemente ligada à magia, ao saber que necessita de iniciação” (idem).

A tradição do enigma, que gradualmente abandonou o caráter espiritual e se secularizou, tornando-se um divertimento palaciano, chegou a nossos dias como recurso de invenção poética, segundo Huizinga: “As escolas líricas modernas, que se movem e residem em domínios geralmente inacessíveis e gostam de envolver o sentido numa palavra enigmática, permaneceram, portanto, fiéis à essência da sua arte” (HUIZINGA, 1994: 150). Despido do caráter metafísico original e da função de passatempo mundano, o enigma foi incorporado na criação poética de autores como Stéphane Mallarmé, Paul Valéry, Lezama Lima, Paul Celan.

Na poesia lírica de Ana Hatherly, desde suas primeiras obras, como o livro A Dama e o Cavaleiro (1960), encontramos o uso livre deste recurso, por exemplo neste poema composto de adivinhas que se chama, justamente, Os Enigmas: “São barcos sem quilha / E passageiro o leme. / O mastro submerso / Na água que voa / E velas, mil velas / Caminham / Na palma das praias / Que crescem com as ondas” (HATHERLY, 1980: 30).

Nesta peça, dividida em três seções, o mistério é construído pela associação inusitada de imagens, que altera o caráter e a função dos elementos, na forma de bizarras metáforas; em outros versos, surgem definições ainda mais estranhas: “O sol é um coral de síntese / Intacta anêmona / Translúcida, fria / E o ventre das conchas / Que geram flores / 
Ondula na sombra / Das sombras da sombra” (idem). Na terceira seção do poema, o vínculo formal com os enigmas é ainda mais explicitada, nos versos "É um peso / Um presságio / Que atinge os arcanos / Secretas cisternas / Dos encantamentos. / As cifras ocultas / Na penugem branca / Ficaram perdidas / Ficaram suspensas / Negaram a esperança / O momento supremo: / Mataram o grifo” (idem, 34).

A referência ao grifo, animal fantástico com cabeça e asas de águia e corpo de leão, é significativa, desde a imagem alegórica até a própria definição do vocábulo, que também quer dizer, conforme o dicionário, "questão difícil, embaraçosa, enigma”, e ainda “elocução ambígua” (HOLLANDA, 1986: 868). A morte do grifo, no poema é justamente o mistério por decifrar: trata-se, possivelmente, de uma representação simbólica do silêncio ou exílio imposto às artes do barroco por uma concepção mais clássica da poesia, avessa ao furor estético da "pérola irregular" 58 .

As metáforas enigmáticas estão presentes em outras obras líricas da autora, como Eros Frenético (1968), O Cisne Intacto (1983), Rilkeana (1999) e mesmo nos poemas em prosa das Tisanas (2006), onde encontramos, por exemplo, as afirmações de que "O mistério supremo é a claridade” (Tisana 121) e “a letra no momento do salto é uma abertura de possibilidades” (Tisana 122). Não causa surpresa encontrarmos o gnomo da obscuridade nesse livro que é uma síntese ou filtro de gêneros literários; o enigma, desde suas origens, é uma forma híbrida, capaz de se associar a outras formas. A hibridização, freqüente na poesia barroca portuguesa, pode ser encontrada, por exemplo, no poema

\footnotetext{
58 O livro A Dama e o Cavaleiro, ao apresentar poemas que dialogam com temas e recursos estilísticos da poesia barroca portuguesa, realiza, de certo modo, um ritual simbólico, intertextual, de ressurreição do grifo. As experiências poéticas do barroco português animariam as aventuras mais radicais do Experimentalismo Poético Português, na década de 1960, em especial no campo da poesia visual, como vimos no primeiro capítulo deste trabalho.
} 
Aplauzos Acadêmicos em honra do Conde de Vila Flor, incluído na coletânea organizada por D. António Álvares da Cunha e comentado por Ana Hatherly em A Casa das Musas. O poema, que se assemelha a uma carta celeste, com o sol no centro de uma série de círculos concêntricos, combina as formas do enigma, do hieróglifo, do labirinto e do anagrama com o propósito de “acumular dificuldades” para assim não apenas demonstrar a "superior capacidade do autor”, mas também a “correspondente virtuosidade do leitor” (HATHERLY: 1995a, 171). Esta divisa nos parece adequada como emblema para sintetizar a obra da própria Ana Hatherly, cultora de insólitos labirintos.

\section{9 - Leitura comparada: $O$ Mestre e Tisanas}

“O jogo não é compreendido pela antítese entre sabedoria e loucura, ou pelas que opõem a verdade e a falsidade, ou o bem e o mal. Embora seja uma atividade material, não desempenha uma função moral, sendo impossível aplicar-lhe as noções de vício e virtude” (HUIZINGA, 2007, 9). Por estar além das dicotomias habituais da ética e da metafísica e assumir “acentuados elementos de beleza” (idem), o jogo está próximo da estética. Estas formulações de Huizinga guardam um forte paralelo com o texto inicial do romance $O$ Mestre, de Ana Hatherly: “A Mentira é recriação de uma Verdade. O mentiroso cria e recria. Ou recreia. A fronteira entre estas duas palavras é tênue e delicada. Mas as fronteiras entre as palavras são todas tênues e delicadas. Entre a recriação e o recreio assenta todo o jogo” (HATHERLY, 2006b: 21).

Nesta passagem programática, além de relativizar as noções de verdadeiro e falso — tema aliás abordado na Tisana $298^{59}$ — , a autora brinca com as diferentes acepções da

\footnotetext{
59 "Era uma vez uma verdade que era defendida pelos inimigos da verdade os quais defendiam a sua desonra. Eram espantosamente certeiros no errado, mas isso acontece muito.” (HATHERLY, 2006a: 116)
} 
palavra jogo, entre elas a de “recreio” (que no dicionário de Aurélio Buarque de Hollanda aparece como “brinquedo”, “passatempo” e “divertimento”), num tom irônico e ardiloso que aponta para outras definições, como “escárnio, ludíbrio” e “manha, astúcia, ardil” (HOLLANDA, 1986: 990). A palavra “recrio” também é estratégica, pois indica o engenho inventivo da autora, que se propôs a escrever um romance que em nada se parece com a tradição clássica do gênero, situado fora das dimensões narrativas tradicionais e com peripécias que se resumem a breves diálogos e poucas ações. O jogo entre recriação e recreio tramado nesta obra "rompe com as fronteiras estabelecidas entre a narrativa e a poesia”, diz Nadiá Paulo Ferreira (HATHERLY, 2006b: 14), inserindo-se, portanto, na zona híbrida e miscigenada de Anacrusa e das Tisanas: não se trata de prosa poética ou romance em versos, mas de texto experimental, que despreza os limites entre os gêneros.

Conforme observou Maria Alzira Seixo na segunda edição portuguesa de $O$ Mestre, há nessa obra “um grande afastamento em relação à definição das estruturas romanescas consideradas normais (tempo, personagens, espaço, intriga)” (HATHERLY, 1976: 10), o que diferencia este livro da "tradição do romance oitocentista que se prolonga (...) pelas primeiras décadas do século XX afora, tanto na Presença quanto no Neo-Realismo” (HATHERLY, 2006b), como escreveu José Carlos Barcello na contracapa da edição brasileira. “Ana Hatherly não escreveu este livro como se Virgínia Woolf e James Joyce nunca tivessem existido. Escreveu a partir do seu legado, sem deixar de se associar à efervescência experimental dos anos 60”, segundo Silvina Rodriges Lopes, em seu prefácio à terceira edição portuguesa do romance (HATHERLY: 1995b, 8) ${ }^{60}$.

\footnotetext{
${ }^{60}$ Marjorie Perloff escreveu em seu livro O momento futurista: “ 'J'aime le romanesque’, observou Roland Barthes numa entrevista em 1975, 'mais je sais que le roman est mort'. O desejo de um 'romancístico' sem as restrições do romance, do 'poético’ que não é mais encaixado no poema - é certamente a nossa própria ânsia
} 
Ao contrário das narrativas ficcionais de cunho linear, em O Mestre "as personagens não têm nome próprio ${ }^{61}$. As palavras que têm como função substituir o nome próprio apontam para o lugar que as personagens ocupam em uma história de amor”, diz Nadiá Paulo Ferreira (HATHERLY, 2006b, 13). Em vez de nomes, o romance traz epítetos para os personagens: assim, temos “uma Discípula que procura obstinadamente um Mestre para amar e ser amada, o que lhe permitiria (...) ‘atingir a Alegria’” (idem, 14), e um Mestre cuja “principal característica é o riso” (idem, 15). “Mestre e discípulo são conceitos fundamentais envolvidos no processo pedagógico que visa a transmissão e renovação de conhecimento”, escreve Silvina Rodrigues Lopes (HATHERLY, 1995b, 11).

“Os Mestres vêm do Oriente”, diz a autora, “confundindo-se com os enigmas das suas falas; são, como Sócrates, exemplares e irônicos (...). Por um movimento de abstractização, o Mestre torna-se todos os mestres” (idem), assim como “a Discípula, que é todos os discípulos” (idem). Ela “representa a capacidade de pergunta e de questionação, a perseguição de uma finalidade que aqui se chama amor ou ciência”, conforme Maria Alzira Seixo (HATHERLY, 1976: 14). Temos aqui tipos dramáticos, portanto, como no teatro vicentino $^{62}$ : o Mestre, com um perfil de monge zen ou sábio taoísta, que prefere o riso, o silêncio ou sentenças enigmáticas a um ensinamento direto da verdade (assim como nos koans budistas, parodiados nas Tisanas); e uma Discípula ávida pelo saber, que para ela é o mesmo que o amor e a alegria (numa palavra: a plenitude).

pos-moderna de romper com as categorias centralizadas e hierarquizadas do passado que faz o momento futurista parecer tão atraente” (PERLOFF, 1993: 20-21).

${ }^{61}$ Nas Tisanas, o personagem-narrador também não é nomeado; apenas o porco de estimação Rosalina possui um nome.

${ }^{62}$ Conforme Ana Hatherly: “O Mestre é um personagem porque é uma pessoa e na origem da pessoa está a máscara. Além disso o Mestre usa máscara, tem máscara, é máscara. Um dos aspectos da sua máscara (ou da sua pessoa) é ser Mestre — usa a máscara de Mestre.” (HATHERLY, 2006b: 22) 
Este livro desconcertante, narrado ora na terceira pessoa, ora na primeira (como as Tisanas), é, paradoxalmente, um ensaio sobre o amor, ou ainda sobre a impossibilidade do amor, um dos temas básicos de Ana Hatherly, sintetizado na Tisana 285: “O verdadeiro amor é um ato indisponível” (HATHERLY, 2006a: 113). Conforme Nadiá Paulo Ferreira, “O Mestre se insere de forma bastante original na tradição do mito de amor das literaturas em língua portuguesa” (HATHERLY, 2006b, 13), embora sem os “artifícios românticos que velam o amor impossível” (idem). A originalidade da autora, diz Ferreira, está na “conjugação entre amor e saber, sendo que este último se torna condição para a descoberta do amor e sua verdade” (idem, 14). O vínculo pedagógico ${ }^{63}$ e de sedução entre Mestre e Discípula é justamente o eixo narrativo do livro, cuja estrutura é similar à de um jogo ${ }^{64}$.

“Começando pelos elementos constitutivos, deparamos com uma introdução em que um narrador apresenta uma espécie de programa teórico relativo ao conhecimento (...) e uma experiência particular que é a relação (...) entre um Mestre e uma Discípula”, escreve Maria Alzira Seixo (HATHERLY, 1976: 13). Após essa abertura programática, o romance apresenta “dez capítulos, divididos em parágrafos, em que o Mestre e a Discípula se perseguem, tentando comunicar e atingir a ciência” (idem). Temos aqui a definição do espaço estrutural em que acontece o jogo, a apresentação dos jogadores e ainda uma breve descrição de suas jogadas. A Discípula anseia obter o amor do Mestre, e todas as ações que desenvolve ao longo do romance são executadas neste sentido; logo, este é o objetivo do

\footnotetext{
${ }^{63}$ Segundo Johan Huizinga, a palavra japonesa asobu significa "estudo sob a direção de um professor ou numa universidade, o que nos faz lembrar o uso da palavra latina ludus no sentido de escola” (HUIZINGA, 2007: 40). Em japonês e em latim, aprender junto a um professor é uma forma de jogo.

${ }^{64}$ Silvina Rodrigues Lopes aponta, no romance de Ana Hatherly, o “jogo lúdico que é tanto o jogo de palavras como a criação de cenas informadas pelos princípios da anamorfose. Reflexão e jogo coincidem desde a apresentação das personagens enquanto tais, que alarga a interrogação da representação à dos próprios limites entre o ficcional e o não-ficcional, até a própria relação entre personagens e conceitos” (HATHERLY, 1995: 11).
} 
jogo. Se ela for vencedora, obterá “a Alegria plena e perfeita, como metáfora da aspiração amorosa” (HATHERLY, 2006b, 15); se for derrotada, poderá recolher resultado inauspicioso, pois, como adverte o Mestre, “há coisas que a gente não deve querer” (idem, 22), este, para ela, é o risco do jogo. Os lances da partida transcorrem em dois cenários básicos, a sala de visitas da casa do Mestre, onde a Discípula vai visitá-lo, e um jardim onde ela tenta simular encontros casuais (lugar simbólico que remete, possivelmente, ao jardim do Éden, com a árvore do conhecimento do bem e do mal, aos labirintos vegetais ${ }^{65}$, ao jardim de Belisa e Don Perlimplin, na peça de Lorca, e ainda ao Parque Eduardo VII, em Lisboa).

As tentativas de sedução da Discípula, observa Nadiá Paulo Ferreira, colocam em cena "a estrutura da paixão: o amante suplica ser correspondido e exige ser amado do modo que ele imagina que se deve amar" (idem, 15). Seguindo uma regra do jogo amoroso, "a Discípula se oferece amável para o Mestre, seduzindo-o, porque o que ela deseja é ser a preferida do seu Mestre. Ou seja: entregar-se ao Mestre e em troca tê-lo no regime de exclusividade” (idem). Essa trama, tradicional na literatura de amor, por si só constitui um jogo; segundo Huizinga, “aquilo que o espírito da linguagem tende a conceber como jogo não é propriamente o ato sexual enquanto tal, trata-se principalmente do caminho que a ele conduz, o prelúdio e preparação do amor, que frequentemente revela numerosas características lúdicas” (HUIZINGA, 2007: 49).

Entre os "elementos dinâmicos do jogo" inerentes ao processo da sedução encontram-se "a criação deliberada de obstáculos, o adorno, a surpresa, o fingimento, a tensão etc.” (idem, 49-50), que podemos identificar em diversas passagens, ao longo da

\footnotetext{
${ }^{65}$ Os labirintos eram construções edificadas geralmente em pedra, mas também havia "labirintos vegetais, inseridos nos jardins, igualmente com todas as suas implicações místicas e lúdicas”, conforme escreveu Ana Hatherly em A Experiência do Prodígio (HATHERLY, 1983: 83).
} 
leitura do romance, como por exemplo, na primeira visita da Discípula à casa do Mestre, em que este cria dificuldades para recebê-la.

Segundo Huizinga, a compreensão do amor como um tipo de jogo é "especialmente, ou mesmo exclusivamente, reservada para as relações eróticas que escapam à norma social” (idem, 50), conceito que ilustramos com o mito de Tristão e Isolda, estudado por Denis de Rougemont em História do Amor no Ocidente (traduzido em Portugal por Ana Hatherly), além de toda a literatura derivada da tradição trovadoresca, até o romantismo do século XIX e mesmo nos dias atuais. No caso de O Mestre, essa ruptura com a "norma social” não está num triângulo amoroso ou adultério, nem mesmo na assimetria de faixa etária ou posição social, mas na impossibilidade física da união erótica, já que o Mestre é homossexual, logo, incapaz de corresponder às expectativas da Discípula.

A dissociação entre eles é marcada também por expressivas diferenças de personalidade: o Mestre que sempre ri é “cheio de contradições” (HATHERLY, 2006b : 29), “perito na arte de simular” (idem, 30), “não sente” (idem, 35), está "sempre a mentir” (idem, 35), “troça de tudo” (idem, 45), é um “anjo indeciso” (idem, 81), comparável a um “muro” (idem). A Discípula, por sua vez, “não gostava de rir nem tampouco de chorar e é por isso que andava à procura da Alegria, já que essa devia excluir o riso e o choro” (idem, 22); ela "tem a mania do encontro das almas" e ainda “a mania do conhecimento, da aprendizagem, é curiosa, ávida, inquisidora, persistente” (idem, 32).

A comunicação entre eles sempre ocorre na fronteira da incomunicabilidade: nas reuniões lúdicas realizadas no jardim ou na casa do Mestre, os diálogos entre o Mestre e a Discípula são concisos, desencontrados, enigmáticos, quase antagônicos, num conflito ou tensão que evidencia a distância, mais do que o encontro entre aquela que ama e aquele que recusa ser amado. Conforme escreve Maria Alzira Seixa, a “perseguição” do Mestre pela 
Discípula “consiste num jogo de contatos de matiz deceptivo”, numa troca de "falas com o mesmo grau de desorientação e intangibilidade (...). Daí que se fale muito, neste texto (falas curtas, incisivas, pouco discursivas), e que não se entenda nada”66 (HATHERLY, 1976: 13). Por vezes, o diálogo entre eles assemelha-se ao teatro de Ionesco, ou ainda aos mondos (diálogos construídos como sucessão de enigmas) dos contos tradicionais zenbudistas, em mais um ponto de contato com as Tisanas, como nesta passagem do oitavo capítulo do romance:

— Então não há esperança de a gente se entender...

— Sim, deve haver, mas não sei bem como. Talvez fechando os olhos e passando a ouvir com os lábios.

— O quê? Descer aos sentidos?

— Quem é que falou em descer ou subir?

- Costuma-se dizer...

— O que é costume aqui não vale nada. É preciso ver tudo a uma nova luz.

— Que luz?

- A luz das trevas.

- Desisto.

— Então ficarás eternamente cego. (HATHERLY, 2006b, 89)

O diálogo entre Mestre e Discípula é lúdico: não comunica uma mensagem unívoca, embora opaca, mas dissimula, oculta, deforma ou confunde o sentido, para além das dicotomias entre verdade e mentira, e portanto fora da esfera de recepção de qualquer tipo de conhecimento. “A comunicação (aprendizagem) revela-se deste modo impossível; a

\footnotetext{
${ }^{66} \mathrm{O}$ tema da incomunicabilidade é outra chave temática comum a esta obra e às Tisanas, onde lemos, na composição de n. 49: "Estou aqui e contemplo o suicídio dos objetos habituais. Na mutilação da própria cadeira em que me sento vejo a morte lenta e saturada que consiste na imolação pela comunicação" (HATHERLY, 2006a: 44).
} 
única progressão realizada no texto é exatamente a descoberta dessa impossibilidade”, escreve Maria Alzira Seixo (HATHERLY, 1976: 14).

O jogo da dissimulação e ocultamento manifesta-se sobretudo na peripécia que transcorre nos episódios do jardim, em que a Discípula persegue furtivamente o Mestre para simular um encontro casual, e ele esquiva-se fingindo ignorar a perseguição, num jogo de avanços e recuos estratégicos, como os movimentos das pedras no tabuleiro de xadrez. Há um pacto lúdico entre eles, para usarmos uma expressão formulada por Affonso Ávila em seu estudo sobre o jogo no universo barroco (ÁVILA, 1994: 64). A própria narradora no romance define o jardim como "um lugar de jogo. Pequeno jogo de roda, pequeno duelo ao longe, pequeno torneio futuro, morte dos jogadores, começo de outro jogo, fim de outro jogo etc. nunca mais acaba” (idem, 79). O espaço dessa aparente brincadeira de escondeesconde é comparado a um círculo mágico, imagem que sugere a idéia de labirinto ${ }^{67}$ :

A Discípula é muito persistente. Vai todos os dias ao Jardim a ver se o fruto já está maduro. Sai calmamente de fora do círculo mágico para dentro do círculo mágico. Entra no Jardim. Começa olhando agudamente para todos os lados. Desce à direita o desenho grego da calçada e vai até ao fim (idem, 77).

Os movimentos da Discípula nesse campo simbólico recordam a perambulação do peregrino dentro de um labirinto barroco, onde ele teria de enfrentar "os perigos e as dificuldades de percurso" para "atingir a Jerusalém celeste, a cidade de Deus, ou seja, a união com Cristo”, conforme escreveu Ana Hatherly em seu estudo A experiência do prodígio - Bases teóricas e antologia de textos visuais portugueses dos séculos XVII e XVIII (HATHERLY: 1983a, 83). A perambulação tinha um caráter iniciático: em sua jornada mística da periferia até o centro da arquitetura simbólica, o peregrino deveria travar um

\footnotetext{
${ }^{67}$ A imagem do labirinto já estava presente na sala de visitas do mestre, cujo sofá tem "desenhos orientais" que lhe dá um aspecto de "tapete persa antigo" (idem, 28). A construção geométrica com arabescos da tapeçaria é similar a formas como a mandala tibetana, o yantra hindu e os labirintos ocidentais, que abordamos no primeiro capítulo deste trabalho.
} 
“confronto consigo próprio através dum combate-percurso cujo objetivo é destruir o mal (se no centro estiver um monstro) ou alcançar a salvação (se no centro estiver a Igreja)” (idem). A Discípula, no início do percurso, encara o Mestre como aquele a quem deseja se entregar, numa união mística (com o sentido de realização e plenitude), como se ele fosse um novo Cristo; num segundo momento, porém, ela o verá como um monstro, o Minotauro a quem é preciso matar (o que causará sua própria destruição), após perceber que o amor entre eles não é realizável, e tampouco a sabedoria ou a alegria.

Silvina Rodrigues Lopes observou que "o tema do desencontro amoroso", no romance, "é responsável pela deambulação labiríntica”, em cujo desfecho macabro a Discípula "vê a sua cabeça capturada como um dos troféus do Mestre que acabara de matar” (HATHERLY: 1995b, 10). Ao destruir seu objeto de desejo, convertido em inimigo monstruoso, a Discípula realiza uma ação de natureza simbólica ou arquetípica: nas palavras de Maria Alzira Seixo, neste romance “a única ação é a da morte e mesmo essa é a mitológica, o Mestre-minotauro morto por Ariana-a-Discípula, amante da luz e da verdade e por ele também assassinada” (HATHERLY, 1976: 16).

A descrição do crime nas páginas finais do romance é alegórica, paródica e não isenta de certo humor negro: a sala do Mestre é convertida numa "gruta ${ }^{68, " ~ o u ~ " c r i p t a ”, ~ q u e ~}$ está "toda decorada de pinturas, de retratos de jovens em movimento e em repouso, cândidos e ágeis guerreiros ou poetas ou copeiros do eterno rei Minos” (HATHERLY, 2006b, 115), numa desterritorialização simbólica de tempo e espaço que converte Lisboa na ilha de Creta. A Discípula "aparece agora criselefantina, pronta a dar o salto mortal por cima da cabeça do Mestre" (idem); ela "paramenta-se de oiro mas deixa o peito nu porque não há

\footnotetext{
${ }^{68}$ Conforme Gustav Hocke, os primeiros labirintos foram construídos em grutas, de onde aliás vem a palavra grotesco (HOCKE, 2005: 115).
} 
veste mais preciosa do que a pele” (idem). O local onde o Mestre dorme, por sua vez, está "rodeado de todos os seus troféus: discípulos e discípulos mortos estão acumulados aos seus pés. Troféus de caça de toda espécie e armas, redes, laços, fundas, venenos repousam ao seu lado” (idem, 116), numa crítica simbólica à pedagogia como forma de poder ${ }^{69}$.

Tal como o Minotauro helênico que devorava as virgens que eram enviadas ritualmente a ele como oferendas, o Mestre se alimentava simbolicamente de seus alunos: “Devorava os discípulos e depois cuspia só aquela grainhazinha deles, quer dizer, aquela mínima porção que não lhe interessava” (idem, 55). A mutação do Mestre em Minotauro ${ }^{70}$ e de Lisboa na ilha de Creta desloca a mímese em favor representação alegórica dos eventos, que atinge seu clímax no reflexo especular do assassinato, ou sacrifício ritual: após matar o Mestre com um golpe de punhal no coração, a Discípula (que assume ao mesmo tempo o papel de Ariadne e de Teseu) “resolve olhar para trás para ver pela última vez o Mestre”, num gesto que recorda o de Orfeu e o da mulher de Lot, e vê a si mesma imolada: o Mestre “segura pelos cabelos a cabeça da Discípula. A cabeça da Discípula está trespassada por um punhal enterrado na fronte até ao punho” (idem, 117). Ao destruir aquele a quem ama, ela destrói ao amor e a si mesma. Conforme Nadiá Paula Ferreira,

O coração como símbolo do amor e a cabeça como símbolo do saber são as causas desse duplo assassinato, em que se alegoriza o percurso do mito do amor na literatura portuguesa, desmistificando o que nele permanece velado, que é a impossibilidade de dois se fazer um. Amante e amado não podem complementar um ao outro, porque o que falta ao amante não é o que o amado tem para lhe oferecer. É na falta constitutiva da subjetividade de todo ser humano que está a origem do amor. Negar isso, no caso da Discípula, ou rir disso, no caso do Mestre, como nos avisa o narrador, "resulta trágico ou do trágico”. (idem, 16)

\footnotetext{
${ }^{69}$ Maria Alzira Seixo já notara, em O Mestre, uma "sátira do ensino como círculo vicioso. Como entronização da ignorância ou do psitacismo” (HATHERLY, 1976:13); Silvina Rodrigues Lopes, por sua vez, observou que "O aparecer do Mestre (...) instaura a relação do ensino como uma relação exorbitante, dissimétrica, sem denominador comum” (HATHERLY, 1995b: 10). O próprio Mestre, falando em primeira pessoa no romance, diz: "Procuro incutir-lhes no ânimo a submissão às regras” (HATHERLY, 2006b: 57).

${ }^{70}$ Convém recordar que o Minotauro é um “monstro andrógino, duplo e ambíguo” (DOURADO, 1974: 6) em que convivem o humano e o animal, a inteligência e o instinto, a solidão e o assassínio.
} 
O jogo da aniquilação recíproca, último lance de uma partida condenada ao fracasso, é prenunciado por outros episódios macabros, inseridos no romance fora de uma ordem cronológica ou de uma sequiência narrativa linear: as ações transcorrem no livro como os movimentos de um sonho, sem uma lógica mimética, tal como vimos em Anacrusa. Estes episódios registram cenas da metamorfose do desejo de fruição erótica num desejo tanático, que sonha com a imolação de si e do outro: no capítulo IV, por exemplo, a Discípula declara que gostaria de enfiar os dentes do Mestre numa fita para colocar em seu pescoço:

De resto foi sempre aí que eu os trouxe, os dentes dele, cravados na minha garganta. É uma maneira de me estrangular com o seu riso. Não creio que ele jamais tenha tido lábios porque lhe eram desnecessários; do que ele precisou sempre foi de dentes, para morder e para rir (idem, 55).

O Mestre é retratado como um gourmet antropófago, "muito voraz”, que "devorava os discípulos”, num festival de iguarias como “mãozinha de discípulo em geléia com molho tártaro" ou ainda ao "molho de vinaigrette" (idem). Quando lhe é servida a carne da Discípula, porém, ele não lhe come as mãos, e sim os olhos, "num prato de osso, talvez de marfim. Provavelmente no marfim dos cem vezes trinta e dois dentes da Discípula” (idem).

No capítulo VI, em vez do banquete canibalesco, temos uma cena de estrangulamento, em que o Mestre toca o corpo da Discípula não para acariciá-la, mas para torturá-la, numa inversão sádica da atitude erótica: “Entretanto o Mestre vai estrangulando a Discípula, mas todos os mestres estrangulam sempre os seus discípulos de uma maneira ou de outra. Toda aprendizagem é uma forma de estrangulamento de alguma coisa dentro de nós ${ }^{71 ”}$ (idem, 70).

\footnotetext{
${ }^{71} \mathrm{O}$ ensino do Mestre não conduz ao amor e à alegria, mas a uma relação de poder em que os discípulos são tragados em um sistema de regras; eles devem se integrar a uma ordem, no qual serão anulados. Esta dimensão política do livro pode ser relacionada ao contexto político de Portugal na época em que o romance foi escrito, quando o país vivia sob o regime ditadorial salazarista. Uma outra caricatura política inserida no
} 
A tensão destrutiva entre o Mestre e a Discípula atinge uma dimensão plástica no capítulo IX, que parodia o célebre quadro A lição de anatomia, de Rembrandt (acervo do Mauritshuis, Amsterdã): aqui, porém, é o cadáver do Mestre que se encontra “completamente nu deitado em cima duma mesa de pedra” (idem, 91), onde será analisado pelos estudantes, que passam a ler suas entranhas, nada encontrando além da escuridão (outra metáfora da incomunicabilidade: o corpo do Mestre convertido numa forma de escritura ilegível, um significante sem significado). Esta passagem, de múltiplos significados e camadas de leitura, sintetiza algumas das principais chaves temáticas do romance, presentes ainda em outras obras da autora, e em especial as Tisanas, como a solidão, a impossibilidade do amor e da sabedoria; tudo é um jogo caleidoscópico, desenhos mutáveis e impermanentes, geometria da transmutação.

Para representar essa visão da instabilidade e do mal-estar do viver no mundo, regido pela insatisfação, pela divisão interna do indivíduo (representada pela metáfora do Andrógino Potencial, ${ }^{72}$ dividido em três partes) e pelo conflito com a ordem estabelecida,

romance é a de Lisboa transformada numa cidade-museu: “A Discípula andava a passear à noite por entre as ruínas da cidade que estava transformada em espetáculo para turistas. A Discípula também é turística, turista e cicerone. Vai dizendo: - Meus senhores, olhai à esquerda o rio...” (idem, 102-103) Em outras passagens mais explícitas lemos: "Tudo faz parte de tudo, não? De resto, ele agora é o rei das ruínas, ou o rei da cidade em ruínas ou o rei das ruínas da cidade. Está arruinado porque vive das ruínas e nelas. Um rei arruinado e triste. Quando um rei está arruinado, como o não estarão seus vassalos?” (idem, 105). O diálogo entre a Discípula (convertida em cicerone) e os turistas sobre a escravidão é ainda mais enfático: “- - Somos todos escravos uns dos outros ou de alguma coisa, ao mesmo tempo que se escravizamos sempre alguma coisa ou alguém. Esta é que é a base da liberdade: para que alguém suba, alguém tem de descer. É como se o espaço em cima ou em baixo fosse limitado ou tão matematicamente regulado que uma determinada deslocação num nível tivesse de produzir inevitavelmente uma deslocação compensadora. Deve ser para manter as forças a um nível desejável. — Quais forças? — As forças da destruição”. (idem, 107)

${ }^{72}$ Segundo Silvina Rodrigues Lopes, “a noção de sujeito dividido é fundamental. O confronto de opostos, como constituição / destruição, vida / morte, não se encaminha nesta novela para nenhuma Aufhebung. Nenhuma plenitude é anunciada em O Mestre, embora o desejo de a atingir - a vontade de harmonia, de perfeição ou alegria — seja um dos impulsos dramatizados na novela (...) Qualquer tipo de oposição é desde o início perturbado pelo desdobramento das personagens, dos temas e das situações. Do lado da Discípula, surge uma 'terceira parte do andrógino potencial', que longe de ser o resultado de uma reconciliação / 
Ana Hatherly atualizou os recursos do barroco em diálogo com as poéticas da vanguarda, numa época em que Portugal se debatia entre a continuação de um regime autoritário já anacrônico na Europa e a saudade de um futuro com dimensões utópicas, que inspiraria a Revolução dos Cravos, em 25 de abril de 1974.

superação é, pelo contrário, uma interferência incontrolada cujo efeito gera inconciliabilidade — do desejo e do seu objeto, do significante e do significado, da vida e da morte”. (HATHERLY, 1995b: 8-9) 


\section{CAPÍTULO III}

\section{VANGUARDA E PÓS-VANGUARDA NA IDADE DA ESCRITA}

O conceito de vanguarda sempre esteve associado ao de ruptura com a tradição, compreendida como repertório de formas históricas superadas pela evolução tecnológica e pelo sentimento de mundo das novas gerações. O entusiasmo pela sociedade urbana e industrial, pelas máquinas, pela velocidade e pelos novos meios de comunicação e de transporte, nas primeiras décadas do século XX, motivou a exigência de "uma arte verbal completamente nova”, conforme escreve Marjorie Perloff em O momento futurista — avant-garde, avant-guerre e a linguagem da ruptura (PERLOFF, 1993: 116). O “discurso tradicional”, prossegue a autora, não podia transportar-se “para essa nova linguagem de telefones, fonógrafos, aeroplanos, cinema, o grande jornal” (idem). Havia um descompasso entre a sociedade moderna e as “formas canônicas do passado", que correspondiam a um certo “estado do mundo” e cuja “carga crítica implícita” e "grau de novidade” estariam “perdidos para sempre”, segundo escreveu o poeta e crítico uruguaio Eduardo Milán no ensaio Poesia: questão de futuro (MILÁN, 2002: 72).

A revolta da modernidade contra os modelos estéticos estabelecidos pela tradição, bem como "o desejo de criar novas formas e incorporar novos temas, característica que vem motivando os artistas ocidentais desde o tempo de Baudelaire” (KOSTELANETZ, 1967: 9), levou os criadores modernos a recusarem a estabilidade, o imobilismo e a repetição em favor do inesperado, do imprevisível, do ignorado, compreendido como informação estética nova por autores como Abraham Moles, para quem a "medida da quantidade de informação” encontra-se “reduzida à medida da imprevisibilidade, isto é, a uma questão de teoria das probabilidades” (MOLES, 1969: 36). A “medida da informação”, diz Moles, “deve ser baseada na originalidade e não na significação” (idem, 41). O novo seria, 
portanto, o inesperado formal, aquilo que surpreende a percepção estética do espectador, por encontrar-se fora de uma cadeia previsível de fenômenos ${ }^{73}$.

O desejo de criar novas estruturas formais, observa Richard Kostelanetz, é cúmplice do próprio devir temporal, pois acompanha processos históricos como “a I Guerra Mundial, a Depressão, a II Guerra Mundial — uma era de arte chegou a um fim somente para ser seguida, em todas as artes, por estilos consideravelmente diferentes” (KOSTELANETZ, 1967: 9). Neste aspecto, prossegue o ensaísta norte-americano, “o século XX sintetiza toda a história da arte”, e cita o historiador cultural Meyer Schapiro, para quem “importantes mudanças econômicas e políticas... são geralmente acompanhadas ou seguidas por mudanças nos centros da arte e em seus estilos” (idem). Com efeito, as transformações ocorridas na sociedade européia entre o final do século XIX e o início do XX foram decisivas para o surgimento das primeiras vanguardas artísticas, que, em dialética contínua com a história, aliaram o projeto da revolução estética a uma expectativa de profundas mudanças sociais, o que André Breton sintetizou em sua conhecida fórmula de que era preciso unir o “mudar a vida” de Rimbaud ao “mudar o mundo” de Marx.

Esta era a convicção que animou artistas e escritores das décadas de 1910 e 1920, como Apollinaire, Maiakovski, Duchamp ou Picabia, que alimentavam a "fé numa revolução próxima que fundiria arte, política e tecnologia” (PERLOFF, 1993: 73). O

\footnotetext{
73 Segundo Abraham Moles, "previsibilidade é a capacidade que tem o receptor de saber, na ordem de desenvolvimento da mensagem, quer seja temporal ou espacial, o que se seguirá a partir do que foi transmitido, de extrapolar a série temporal ou espacial dos elementos da mensagem (Wiener), de imaginar o futuro de um fenômeno a partir do seu passado. Esta previsibilidade só pode ser evidentemente de natureza estatística, não tendo um aspecto absoluto e sim quantitativo; há um grau de previsibilidade que não é outra coisa senão um grau de coerência do fenômeno, uma taxa de regularidade” (MOLES, 1969: 100). Partindo das concepções de Moles, o poeta experimental português Antônio Aragão afirma: "podemos dizer que a aventura artística caminha sempre do improvável ao possível, constantemente fazendo e refazendo este longo caminho inesgotável de previsões e imprevistos. Exatamente por isso a arte surge como um jogo necessário onde as possibilidades são incontáveis. Pelo que o acaso entra no jogo e tem uma contínua importância subjacente.” (HATHERLY, 1981: 103)
} 
“momento futurista”, expressão aliás criada por Renato Poggioli em Teoria dell'arte di avanguardia, correspondeu a uma "breve fase utópica do modernismo inicial, quando os artistas se sentiram às vésperas de uma nova era, que seria mais excitante, mais promissora e mais inspiradora do que qualquer outra precedente” (PERLOFF, 1993: 80).

Ou ainda, como escreveu Ana Hatherly no ensaio A reinvenção da leitura: “A depuração que os movimentos de vanguarda (...) têm procurado exercer no campo da literatura e das artes é o reflexo da mudança que se opera e se quer implantar na sociedade em que se produz” (HATHERLY, Ana, e MELO E CASTRO, E. M.: 1981, 150). “A literatura de vanguarda, que surge na sociedade burguesa, é antiburguesa”, diz a autora portuguesa. “Insurge-se 'contra a literatura' na medida em que esta reflete, ilustra a decadência da classe dominante, que dela se apropriou, tornando-a inoperante pelo uso rotineiro, institucionalizado, que é o da cultura oficial” (idem). A insurgência das vanguardas contra a cultura burguesa logo assumiu o aspecto da militância política comunista ou fascista, expressões opostas do mesmo ideal de virar o mundo pelo avesso.

O teórico italiano Renato Poggioli, escrevendo sobre os elementos típicos do espírito vanguardista, cita o “antagonismo: age-se contra alguma coisa ou contra alguém” (por exemplo, o estado, a burguesia, as instituições acadêmicas); o "culto da juventude" (identificada com a vitalidade, a energia, a oposição ao antigo); e a preponderância da poética sobre a obra” (ECO: 1991, 93), ou seja, as teses defendidas nos manifestos e a concepção revolucionária da obra artística eram mais importantes do que a própria obra.

A esse respeito, Umberto Eco faz uma importante distinção entre vanguarda e experimentalismo, em seu livro Sobre os espelho e outros ensaios: "O experimentalismo joga com a obra em si, da qual qualquer um poderá extrapolar uma poética, mas que vale antes de mais nada como obra” (idem), enquanto a vanguarda "joga com o grupo de obras 
ou de não-obras, algumas das quais são meros exemplos de poética” (idem). A conclusão do autor italiano, concisa e severa, é que "no primeiro caso, da obra extrapola-se uma poética; no segundo caso, da poética extrapola-se a obra” (idem). A partir da definição de Eco, podemos considerar os Cantos de Pound ou o Finnegans Wake de Joyce como obras experimentais, já que tendem a uma “provocação interna à história de determinada instituição literária (romance como anti-romance, poesia como não poesia)” (idem, 93-94). Já os manifestos de Marinetti pertencem à vanguarda, pois visam uma "provocação externa, isto é, quer que a sociedade como um todo reconheça a sua proposta como um modo ofensivo de entender as instituições culturais, artísticas e literárias” (idem, 94) ${ }^{74}$.

Em ambos os casos, porém, a contestação está presente, seja no aspecto de ativismo, que Poggioli define como “entusiasmo, fascínio pela aventura, gratuidade de fins”, seja no aspecto de niilismo, ou “desprezo pelos valores correntes” e vontade de "por abaixo os obstáculos tradicionais” (idem, 93). O ativismo das tendências surgidas nas décadas de 1910 e 1920 — futurismo, dadaísmo, surrealismo etc — esgotou-se, porém, nas décadas subseqüentes, em grande parte devido a fatores políticos: a perseguição efetuada aos artistas inovadores pelos regimes políticos totalitários e a devastação causada pela II Guerra Mundial. A primeira onda da vanguarda teve o seu fim causado pela mesma tecnologia, energia e militarismo saudados em seus manifestos.

Após um período de novo realismo social, no pós-guerra, ativo especialmente no romance e no cinema, a segunda metade do século $\mathrm{XX}$ assistiu à segunda onda de movimentos vanguardistas ou experimentais nas décadas de 1950-1970, com a Poesia

\footnotetext{
${ }^{74}$ A distinção entre experimentalismo e vanguarda não é aceita por autores como E. M. de Melo e Castro, para quem a poesia experimental "se preocupa com as bases e a evolução do ato poético e do poema como objeto. $\mathrm{O}$ estudo do resultado das experiências realizadas é fundamental. Nesse estudo reside de fato o valor de projeção do ato criador experimental. Por ele a poesia experimental é sinônimo de Arte de Vanguarda" (HATERLY, Ana e MELO E CASTRO, E. M.: 1981, 109).
} 
Concreta, a Language Poetry, o Neobarroco latino-americano, o Oulipo francês e o Experimentalismo Poético Português $(P O-E X)$, que retomaram a retórica, a pesquisa formal e o espírito utópico de seus antecessores, mas num contexto histórico distinto e aplicando diferentes vias de elaboração formal. Não é nosso propósito discutirmos cada uma dessas tendências, mas fazermos um paralelo entre o Experimentalismo Poético Português e as vanguardas históricas para apontarmos a sua condição de singularidade.

O movimento da $P O-E X$ surge numa época conturbada pela Guerra Fria, marcada por eventos como Guerra do Vietnã, os movimentos feministas e estudantis, a luta contra a discriminação racial, a expansão da contracultura e da música pop, a divulgação de filosofias orientais e por acontecimentos tecnológicos como as viagens espaciais. Portugal vivia então numa das últimas ditaduras de direita da Europa, comandada por Antônio Salazar (o outro regime autoritário era o de Francisco Franco, na Espanha), que sonhava em manter o domínio colonial em países como Angola e Moçambique e preservar um sistema nacionalista, messiânico e militarista, há muito anacrônico no continente europeu.

Conforme diz Ana Hatherly no livro Um calculador de improbabilidades, os poetas e intelectuais portugueses sentiram "uma premente necessidade de mudança e de abertura ao mundo”, mas também “uma necessidade íntima de rigor, de transparência e de audácia incomuns nesse tempo" (HATHERLY, 2001: 9). A PO-EX, prossegue a autora, "reflete essa conjuntura e ilustra-a à sua maneira, ao assumir uma postura de insubordinação estética e cívica”, característica de todas as tendências de vanguarda do século XX, mas é um fenômeno "peculiar na medida em que foi simultaneamente uma revolta contra o status quo local e a integração numa recusa dos valores de um establishment internacional, que se tornara intolerável para os jovens de então” (idem). 
O sentimento de desconforto em relação ao regime salazarista e o desejo de manifestar o repúdio na forma de uma arte inovadora foram essenciais à definição dos vetores estéticos e ideológicos da $P O-E X$, que tem como marcos fundadores os lançamentos das revistas Poesia Experimental, em 1964, e Operação, em 1967, além de happenings como o Concerto e Audição Pictórica (1965), a exposição coletiva VisoPoemas (1965) e a Conferência Objeto (1967), que reuniram poetas, músicos e artistas visuais.

O caráter provocativo e performático desses eventos é herdeiro do espírito de transgressão das vanguardas históricas, presente na leitura do "extenso poema sonoro" Zang Tumb Tuuum por Marinetti, que "explora a capacidade do perfomer para usar a voz, gesto e entonação", conforme diz Marjorie Perloff em O momento futurista (PERLOFF, 1993: 119), ou ainda nas intervenções de Maiakovski nos cabarés de Moscou, em que o poeta se apresentava com as faces pintadas ou com a célebre gravata amarela, conforme relata Angelo Maria Ripellino em Maiakovski e o teatro de vanguarda (1971).

No Concerto e Audição Pictórica, realizado em Lisboa, em 1965, com a participação de poetas como Salette Tavares, Melo e Castro e de músicos como Jorge Peixinho, foram tocadas composições de John Cage, com a colaboração adicional de um caixão, um piano de meia cauda, instrumentos de percussão vários, balões, metrônomos, uma harpa, um piano de criança, palavras soltas, chocalhos de várias espécies, com e sem badalo, uma flauta de bisel, uma couve, um bidê, risos, pandeiretas, música de Chopin, um ré-ré, um despertador, um rolo de papel higiênico, um jarro de água, um brinquedo de corda, 2 violinos de criança (brinquedos), uma máquina de barbear elétrica, um cravo (flor), uma casa de cão que ladra (brinquedo), pratos, guizos, um apito, espaço tempo, ritmo, luz, silêncio, uma pistola (brinquedo)” (HATHERLY, Ana, e MELO E CASTRO, E. M.: 1981, 46).

Já na Conferência Objeto, realizada na Galeria Quadrante, durante o lançamento das revistas Operação 1 e 2, foi preparado um ambiente para o público que recorda a técnica da instalação, com as folhas de cartolina que compunham o primeiro número da revista 
“dispostas na parede como numa exposição de pintura normal, suspensas de fios de nylon, mas sem moldura” (idem, 77), enquanto no chão da sala foram colocadas várias capas da OP.-1, “formando cubos em dois cantos da sala” (idem). No texto A crítica então, publicado sem crédito no livro PO-EX - Textos teóricos e documentos da poesia experimental portuguesa, o autor afirma que, com tais provocações, a vanguarda portuguesa "atacou e ataca destrutivamente o código fossilizado da leitura sentimentalista e opressiva da língua portuguesa no momento preciso em que o sistema fascista dele mais se reclama”, no início da década de 1960, com o objetivo de "galvanizar o povo para as guerras do Ultramar” (HATHERLY, Ana e MELO E CASTRO, E. M. 1981: 176).

A resistência estética era, em si mesma, um ato político, pois indicava outras possibilidades de comunicação e, portanto, de relacionamento entre indivíduo, sociedade, arte e história. A ruptura proposta pelos experimentalistas portugueses, porém, não significou uma recusa de toda a tradição literária, à maneira dos futuristas italianos, que opunham o automóvel à Vitória de Samotrácia e defendiam a destruição de museus e bibliotecas. Os experimentalistas recusavam a dicção lírico-discursiva, o sentimentalismo, a retórica, mas propunham o diálogo com o que houve de mais inventivo no passado.

“Nós falamos sempre em ruptura”, diz Melo e Castro, "mas essa ruptura diz respeito a um convencionalismo que nos era imposto, nunca ruptura com uma tradição que era preciso reconstruir” (idem, 20-21). Como exemplo da reconstrução ou reinvenção do passado, diz o autor, “fomos, por exemplo, desenterrar a Poesia Barroca Portuguesa, fomos recuperar, fazer uma revisão crítica das fontes culturais que eram sistematicamente, por uma razão ou (...) sistematicamente ocultadas” (idem, 21). E Ana Hatherly declara que “essa ruptura é uma recusa do ambiente que nos rodeia, e nunca é uma ruptura com as nossas raízes. (...) Pois, porque na verdade muitos dos meus trabalhos têm base numa 
espécie de quase reelaboração de maneiras de trabalhar antigas” (idem). A eleição de um repertório inventivo com o qual se poderia dialogar, o repertório barroco, maneirista e dos alfabetos arcaicos, é o que distingue, essencialmente, a $P O-E X$ das vanguardas históricas, que pretendiam criar algo totalmente novo, sem raízes em nenhuma tradição. Como vimos no primeiro capítulo deste trabalho, o diálogo com o barroco, e com a forma do labirinto poético em especial, foi decisivo para a evolução do trabalho poético de Ana Hatherly.

A colaboração entre poesia, música, performance e artes visuais, em direção a uma “arte total” que unisse as diferentes formas de expressão (projeto que tem como antecessores a missa barroca, o drama musical wagneriano e manifestações das vanguardas históricas, e que assumiria novas feições com a proposta concretista da linguagem verbivocovisual, neologismo criado por James Joyce e adotado no Plano-Piloto da Poesia Concreta) foi uma das preocupações centrais da $P O-E X$. Para a realização dessa ousada aventura que hoje nós chamaríamos de multimídia, no entanto, os experimentalistas contavam com extrema carência de recursos, compensada pelo esforço imaginativo.

“Uma das características fundamentais da Poesia Experimental Portuguesa é a sua escassez de meios”, afirmou Melo e Castro numa mesa-redonda realizada na Bienal de São Paulo, em 1977 (HATHERLY, Ana e MELO E CASTRO, E. M.: 1981, 24). "Nós trabalhamos sempre com meios pobres, (...) com coisas feitas à mão por nós próprios, nunca tivemos acesso a mecanismos sofisticados — foi assim que nós enfrentamos a era eletrônica e a era cibernética” (idem). Apesar disso, os experimentalistas mantiveram-se bem-informados sobre o que havia de mais avançado na época, desde a teoria da informação, o estruturalismo, a semiótica, até as pesquisas realizadas pela vanguarda internacional, e em particular com a Poesia Concreta. Os primeiros resultados apresentados pela $P O-E X$, em suas revistas e performances realizadas na década de 1960, apontam já o caminho de 
singularidade que seria percorrido nos anos posteriores, em que as influências concretistas foram somadas às do barroco, da caligrafia oriental e da pesquisa científica, em obras planejadas e executadas de acordo com regras específicas. Conforme escreve Ana Hatherly,

Nesse tipo de criação poética (experimental) o mais significativo fator é o da experiência (...). As regras que o poeta a si próprio impõe são as regras do jogo que ele executa e persegue com idéias, palavras e atos. A obra criadora não é tanto o poema: o poema é apenas o resultado. O mais importante é o conjunto de regras que o poeta a si próprio impõe, as possibilidades desse conjunto de regras (idem, 133).

O segundo número da revista Operação, que contou exclusivamente com poemas de Ana Hatherly, traz um detalhado programa em que a autora apresenta, de modo conciso, a experiência realizada em cada um dos poemas do ciclo. Assim, por exemplo, ela define o “Tipo A” como “deslocação semântica de uma palavra privilegiada num contexto”; o “Tipo E” seria a “deslocação por metáfora e metonímia”, e assim por diante (HATHERLY, 2001: 71). Esse tipo de programa, que já abordamos na Introdução, quando nos referimos a Leonorana, é essencial ao projeto experimentalista, pois evita a leitura caótica, dispersiva, sem limites de interpretação. A obra poética experimental, concebida a partir de regras específicas, concilia a pluralidade de leituras com um planejamento rigoroso efetuado pelo poeta, que está mais preocupado com o processo criativo do que com a obra acabada.

A visão estratégica da operação poética experimental, sem dúvida, afasta-se do subjetivismo expressionista, da retórica futurista, da anarquia dadá e do automatismo surrealista, aproximando-se das realizações do construtivismo russo e da noção do poema como estrutura defendida pelos poetas brasileiros do grupo Noigandres. A relação entre a PO-EX e a Poesia Concreta, porém, não foi de adesão incondicional e continuidade, havendo mesmo um momento de ruptura, no caso de Ana Hatherly, que agora vamos examinar. No ensaio A reinvenção da leitura, a autora reconhece que o movimento da Poesia Concreta "é fundamental para a evolução da leitura na medida em que contribui 
para que o texto deixe de ser apenas uma expressão lírico-literária para se tornar por fim uma pura combinação de sinais, estabelecendo desse modo uma nova trajetória da palavra para o signo”, alargando o âmbito de leitura "para fora dos limites literários tradicionais” (HATHERLY, Ana e MELO E CASTRO, E. M.: 1981, 148).

No entanto, “ao pretender que o poema concreto fosse imediatamente legível (...), isto é, sem a intervenção duma leitura decifradora, os seus teorizadores condenavam-no ao esgotamento imediato” (idem, 144). Os ideais de objetividade e rapidez comunicativa da Poesia Concreta, que dialogou com a linguagem do jornal, do jingle, do out-door, contrastava com a poesia mais cifrada, enigmática ou barroquista da poeta portuguesa, que por vezes se aproxima de uma deliberada abstração plástica, como nos Mapas da imaginação e da memória, no romance visual O escritor, em Leonorana e outras obras.

“Para os concretistas europeus, sobretudo os germânicos e os anglo-saxãos”, escreve Ana Hatherly, “a importância do aspecto formalmente visual acaba por impor-se e até sobrepor-se ao aspecto literário" (idem), reatando as relações com uma “tradição da vanguarda (embora esses termos possam parecer incompatíveis) em que língua, som, imagem se confundem, derrubando declaradamente as fronteiras entre as artes” (idem).

Como resultado da primazia estratégica do grafismo sobre a referencialidade, prossegue a autora, desenvolveram-se outras modalidades de poesia experimental, como “o poema visual, (...); a poesia objetiva, que implica a realização de objetos tridimensionais e a colaboração de músicos; (...); a poesia cinética ${ }^{75}$, tátil etc.” (idem, 147), até se alcançar o limite extremo da poesia-espetáculo, que se liga ao happening” (idem).

\footnotetext{
${ }^{75}$ Conforme Melo e Castro, a poesia cinética "propõe uma noção de sintaxe dinâmica, isto é, de uma possível e exeqüível modificação das relações entre os elementos simples que constituem as estruturas dos poemas, indo até a sua total modificação ou mesmo destruição - caso o utente do poema cinético o deseje. O caráter efêmero dos materiais em que estão realizados os poemas (papel e cartão) implica justamente que eles, sendo
} 
Antônio Aragão, poeta que participou ativamente do movimento da $P O-E X$, relata a experiência pioneira que realizou no campo da poesia eletrônica, com a colaboração do italiano Nanni Balestrini e de um computador da IBM, que resultou na criação de mais de três mil variações do mesmo grupo de versos. Aragão afirma, no artigo A arte como campo de possibilidades (que evidencia, já no título, o vínculo com a teoria de Abraham Moles), que "a regra de partida forneceu um princípio que originou a possibilidade. Em seguida, o cérebro IBM tentou todas as combinações” (idem, 105). Segundo o poeta português, “é indiscutível o alto nível lírico de alguns poemas. Aqui o homem fabrica o próprio calculador de possibilidades colocando-se depois como fruidor atento perante o milagre do imprevisível” (idem).

A experiência pioneira desenvolvida por Aragão, numa época em que era muito difícil o acesso a sistemas de informática, teve um extraordinário desenvolvimento nas décadas posteriores, graças à revolução tecnológica, que favoreceu o surgimento da nova poesia eletrônica, ou infopoesia, que tem hoje, entre seus expoentes, o português E. M. de Melo e Castro e os brasileiros Augusto de Campos, Arnaldo Antunes e André Vallias.

As mídias eletrônicas oferecem suportes dinâmicos e interativos no ambiente da internet, que realiza o sonho das vanguardas históricas de unir o som, a imagem, a palavra e o movimento, transcendendo as fronteiras nacionais e os limites da escrita - ou ainda ampliando a noção de escrita para além do seu sentido convencional, como Ana Hatherly prenunciou em seus labirintos visuais, como $O$ escritor e os Mapas da imaginação e da memória, realizados nas décadas de 60 e 70 com notória carência de recursos materiais.

uma evolução dinâmica do 'livro', convidam muito mais a uma utilização, a um consumo e por fim a uma destruição orgânica, que a uma simples leitura ou percepção visual” (HATHERLY, Ana e MELO E CASTRO, E. M.: 1981, 159-160). 
Neste sentido, podemos considerar que a era tecnológica, ao potencializar os aspectos sonoros, imagéticos e dinâmicos da linguagem, confirma as profecias da autora portuguesa, para quem “A noção de ESCRITA alargou-se / a TUDO / a QUASE TUDO / porque a escrita é sinônimo de IMAGEM / imagem para se ver / para se ter / para se ser / Escrevo para compreender / para apreender: / a escrita é o que me revela / um mundo / o mundo” (HATHERLY, Ana. 2005: 58). As novas tecnologias, ao "reinventarem a escrita” na tela de cristal líquido, retomam, ao mesmo tempo, a antiga tradição dos calígrafos, escribas, poetas-pintores e criadores de labirintos estudados por Ana Hatherly em A experiência do prodígio, numa reconciliação entre passado e presente, tradição e modernidade. 


\section{CONCLUSÃO}

Ana Hatherly, em sua pesquisa sobre a poesia visual barroca dos séculos XVI e XVII, longe de realizar um esforço de mera arqueologia literária, apresenta questões conceituais, formas e processos criativos que se relacionam com o pensamento e formas de representação estética das vanguardas da segunda metade do século XX.

Nosso estudo teve como objetivo desenvolver essa aproximação entre os textos visuais barrocos e a modernidade, que foi fundamental para a criação poética da própria Ana Hatherly, conforme vimos na análise de obras como Leonorana e O escritor.

Na introdução, fizemos uma breve descrição dos temas abordados, e em particular do conceito de obra aberta, formulado por Umberto Eco e Haroldo de Campos, que é essencial para a compreensão do pensamento estético da modernidade.

No primeiro capítulo, fizemos uma investigação do labirinto como estrutura ou rede que propicia diferentes caminhos de leitura e interpretação. Dentro deste tópico, abordamos aspectos históricos da forma arquitetônica dos labirintos, sua transposição para a forma literária, ainda na antiguidade, seu desenvolvimento na época barroca e os paralelos possíveis com obras de vanguarda como O lance de dados de Mallarmé, o Finnegans Wake de Joyce e obras da própria Ana Hatherly, como O escritor.

A relação entre a poesia e a pintura é outro tema desenvolvido nesse capítulo, assim como o resgate de alfabetos arcaicos, que a poeta estudou com o objetivo de desenvolver uma nova forma de escrita, em que a materialidade dos signos visuais se sobrepõem à referencialidade. É o que a autora chama de reinvenção da escrita, que exige uma outra forma de participação do leitor, numa reinvenção da leitura. 
As experiências realizadas por Ana Hatherly nesse campo, como a série de desenhos Mapas da imaginação e da memória, são formas híbridas entre a poesia, a narração e a pintura, e seguem um princípio construtivo próximo ao conceito da obra aberta e à forma do labirinto barroco, pela pluralidade de rotas interpretativas.

As experiências visuais, no entanto, são apenas uma parte da obra da poeta portuguesa, que realizou também interessantes experiências no campo da prosa de invenção, como nos livros 463 Tisanas, $O$ mestre e Anacrusa, que são estudados no segundo capítulo. Embora sejam obras de caráter diverso de Leonorana ou de $O$ escritor, por exemplo, podemos reconhecer aqui uma escrita labiríntica.

Ana Hatherly recusa o modelo linear da prosa narrativa, com desenvolvimento do tipo início-meio-fim; não há dimensões reconhecíveis de tempo e espaço, as intrigas são reduzidas ao mínimo e os personagens, em geral, não têm nome. Por outro lado, a autora incorpora recursos da estrutura dos jogos e da linguagem dos sonhos, faz uso de fábulas, parábolas, enigmas e paradoxos, dando ao texto o caráter de um labirinto destituído de centro, em que o leitor pode trilhar múltiplos caminhos de interpretação.

No terceiro capítulo deste trabalho, discutimos o conceito de vanguarda, a partir de formulações de autores como Richard Kostelanetz, Renato Poggioli e Marjorie Perloff, em paralelo com as tendências estéticas do início do século XX, com o objetivo de apontar a singularidade do Experimentalismo Poético Português (PO-EX), de que Ana Hatherly foi uma das principais teóricas e criadoras.

Nosso objetivo, aqui, não foi apenas fazer uma exposição conceitual e diacrônica (embora façamos uma breve contextualização histórica), mas sobretudo ressaltar a excepcionalidade do caso português, que, ao contrário do comportamento esperado de movimentos inovadores, não recusa a tradição, mas recupera um passado 
de invenção, em diálogo criativo com o presente, sem cair nas tentações da pósmodernidade. A esse respeito, incluímos, já na Introdução, o parecer de Guy Scarpetta, para quem a releitura crítica do barroco não se confunde com o pastiche de estilos históricos pela pós-modernidade por sua “exigência de invenção, de estilo”, enquanto o pós-modernismo, “tal como o kitsch, poderia definir-se como a incapacidade de criar um estilo, e pela pura substituição da invenção pela citação” (PEREIRA, 1990: 55).

Outra questão destacada neste capítulo é a relação de Ana Hatherly com a Poesia Concreta, que exerceu forte influência entre os jovens autores portugueses na década de 1960. Conforme demonstramos, embora a autora reconheça a importância do trabalho do grupo Noigandres para a recuperação do caráter visual da escrita e incorpore seus procedimentos estruturais e sintáticos na fase inicial do movimento experimentalista, ela posteriormente se afasta da visão concretista, para buscar outros caminhos criativos.

Enquanto os poetas concretos brasileiros, herdeiros da lição de clareza e objetividade de Ezra Pound, buscavam a rapidez comunicativa do cartaz, Ana Hatherly buscava outro tipo de escrita, em que a visualidade se sobrepõe ao sentido, numa deliberada abstração imagética, que vamos encontrar em diferentes momentos de sua obra criativa, e em especial em O escritor e nos Mapas da imaginação e da memória.

Por fim, fazemos um pequeno paralelo entre a concepção de Ana Hatherly da reinvenção da escrita e as novas possibilidades oferecidas pela revolução tecnológica, que permite concretizar o ideal experimentalista de unir imagem, som, palavra e movimento, rompendo limites entre fronteiras idiomáticas e geográficas. A nova poesia eletrônica ou digital hoje em curso, que tem entre seus cultores E. M. de Melo e Castro, é a nosso ver a continuação lógica do trabalho iniciado pela $P O-E X$, que longe de ser uma referência morta ou distante coloca-se novamente dentro do olho do furacão. 


\section{REFERÊNCIAS BIBLIOGRÁFICAS:}

\section{Bibliografia da autora:}

\subsection{POESIA:}

1.1.1 Um ritmo perdido. Lisboa: ed. do autor, 1958.

1.1.2 As aparências. Lisboa: Sociedade de Expansão Cultural, 1959.

1.1.3 A dama e o cavaleiro. Lisboa: Guimarães Editores, 1960.

1.1.4 Sigma. Lisboa, 1965.

1.1.5 Estruturas poéticas — Operação 2. Lisboa, 1967.

1.1.6 Eros frenético. Lisboa: Moraes Editores, 1968.

1.1.7 39 tisanas. Porto: Colecção Gêmeos, 1969.

1.1.8 63 tisanas. Lisboa: Moraes Editores, 1970.

1.1.9 Anagramático. Lisboa: Moraes Editores, 1970.

1.1.10 Poesia (1958-1978). Lisboa: Moraes Editores, 1970.

1.1.11 A reinvenção da leitura. Lisboa: Futura, 1975.

1.1.12 Joyciana (ob. col.). Lisboa. \& Etc, Edições Engrenagem, 1982.

1.1.13 O cisne intacto. Porto: Edições Limiar, 1983.

1.1.14 A cidade das palavras. Lisboa: Quetzal, 1988.

1.1.15 Escrita natural. Lisboa: Galeria Diferença, 1988.

1.1.16 Volúpsia. Lisboa: Quimera, 1994.

1.1.17 77 tisane. Verona: Colpo di Fulmine Editore, 1994.

1.1.18 351 tisanas. Lisboa: Quimera, 1997.

1.1.19 Tisanas. Berlim: Edition Tranvia, 1998.

1.1.20 Tisanas. Cidade do México: Verdehalago, 1998. 
1.1.21 A idade da escrita. Lisboa: Edições Tema, 1998.

1.1.22 Rilkeana. Lisboa: Assírio \& Alvim, 1999 (prêmio PEN Club).

1.1.23 Um calculador de improbabilidades. Lisboa: Quimera, 2001.

1.1.24 Théatres de la parole. Billière: Editions Vallongues, 2002.

1.1.25 O pavão negro. Lisboa: Assírio \& Alvim, 2003.

1.1.26 A mão inteligente. Lisboa: Quimera, 2003.

1.1.27 Itinerários. Vila Nova de Famalicão: Quási, 2003.

1.1.28 Fibrilações I e II. Lisboa: Quimera, 2004/05.

1.1.29 A idade da escrita e outros poemas (organização e prefácio de Floriano Martins). São Paulo: Editora Escrituras, 2005.

1.1.30 463 tisanas. Lisboa: Quimera, 2006.

1.1.31 A Neo-Penélope. Lisboa: ETC., 2007.

\subsection{FICÇÃO:}

1.2.1 O mestre. Lisboa: Arcádia, 1963; 2ª . ed., Lisboa: Moraes Editores, 1976; 3ª ed., Lisboa: Quimera, 1995.

1.2.2 O mestre. Rio de Janeiro: Sette Letras, 2006.

1.2.3 O escritor. Lisboa: Moraes Editores, 1975.

1.2.4 Crônicas, anacrônicas, quase-tisanas e outras neo-prosas. Lisboa: Iniciativas Editoriais, 1977.

1.2.5 Anacrusa. Lisboa: \& Etc, Edições Engrenagem, 1983.

1.2.6 ELLES - Um espistolado (com Alberto Pimenta). Lisboa: Editorial Escritor, 1999.

\subsection{ENSAIOS E EDIÇÕES CRÍTICAS:}

1.3.1 Nove incursões. Lisboa: Sociedade de Expansão Cultural, 1962.

1.3.2 O espaço crítico. Lisboa: Editorial Caminho, 1979. 
1.3.3 PO.EX - Teóricos e documentos da poesia experimental portuguesa (com E. M. de Melo e Castro). Lisboa: Moraes Editores, 1981.

1.3.4 A experiência do prodígio — bases teóricas e antologia de textos-visuais portugueses dos séculos XVII e XVIII. Lisboa. Imprensa Nacional - Casa da Moeda, 1983.

1.3.5 Defesa e condenação da Manice. Lisboa: Quimera, 1989.

1.3.6 Poemas em língua de preto dos séculos XVII e XVIII. Lisboa: Quimera, 1990.

1.3.7 Elogio da pintura (com Luís de Moura Sobral). Lisboa: Instituto Português do Património Cultural, 1991.

1.3.8 A preciosa, de Sóror Maria do Céu. Lisboa: Instituto Nacional de Investigação Científica, 1991.

1.3.9 Lampadário de cristal, de frei Jerónimo Babia. Lisboa: Editorial Comunicação, 1991.

1.3.10 O desafio venturoso, de António Barbosa Bacelar. Lisboa: Assírio \& Alvim, 1991.

1.3.11 O triunfo do rosário, de sóror Maria do Céu. Lisboa: Quimera, 1992.

1.3.12 A casa das musas. Lisboa: Editorial Estampa, 1995.

1.3.13 O ladrão cristalino. Lisboa: Editorial Cosmos, 1997 (Prémio de Ensaio $\mathrm{APE} / \mathrm{TEelecom})$.

1.3.14 Frutas do Brasil, de frei António do Rosário. Lisboa: Biblioteca Nacional, 2002.

1.3.15 Poesia incurável. Lisboa: Editorial Estampa, 2003.

1.3.16 Interfaces do olhar. Lisboa: Roma Editora, 2004.

\subsection{CATÁLOGOS DE EXPOSIÇÕES:}

1.4.1 Hand made. Lisboa: Fundação Calouste Gulbenkian, 2000.

1.4.2 Obra visual: 1960-1990. Lisboa: Fundação Calouste Gulbenkian, 1992.

1.4.3 Mapas da imaginação e da memória. Lisboa: Moraes Editores, 1973. 


\section{Bibliografia ativa}

2.1 Livros de Ana Hatherly citados:

2.1.1 HATHERLY, Ana. 463 tisanas. (cit., 1.1.30 )

2.1.2 HATHERLY, Ana. O mestre. (cit., 1.2.2)

2.1.3 HATHERLY, Ana. Um calculador de improbabilidades. (cit., 1.1.23)

2.1.4 HATHERLY, Ana. A idade da escrita e outros poemas. (cit., 1.1.29)

2.1.5 HATHERLY, Ana. Interfaces do olhar. (cit., 1.3.16)

2.1.6 HATHERLY, Ana. Hand made. (cit., 1.4.1)

2.1.7 HATHERLY, Ana. O ladrão cristalino. (cit, 1.3.13)

2.1.8 HATHERLY, Ana. A casa das musas. (cit, 1.3.12)

2.1.9 HATHERLY, Ana. Obra visual: 1960-1990. (cit., 1.4.2 )

2.1.10 HATHERLY, Ana. Anacrusa. (cit., 1.2.5)

2.1.11 HATHERLY, Ana. A experiência do prodígio - bases teóricas e antologia de textos visuais portugueses dos séculos XVII e XVIII. (cit., 1.3.4)

2.1.12 HATHERLY, Ana. Poesia 1958-1978. (cit., 1.1.10)

2.1.13 HATHERLY, Ana. O espaço crítico — do simbolismo à vanguarda. (cit., 1.3.2)

2.1.14 HATHERLY, Ana. O mestre. (cit., 1.2.1)

2.1.15 HATHERLY, Ana. O escritor. (cit., 1.2.3)

2.1.16 HATHERLY, Ana e MELO E CASTRO, E. M. PO-EX: textos teóricos e documentos da poesia experimental portuguesa. (cit., 1.3.3)

\subsection{Artigos sobre Ana Hatherly:}

2.2.1 ENGELMAYER, Elfriede. Tudo o que é profundo se revela à superfície. In: Interfaces do olhar — Uma antologia crítica, Uma antologia poética. Lisboa: Roma Editora, 2004. p. 65-68. 
2.2.2 FERREIRA, Nádia Paulo. O lugar do sujeito em Tisanas. In: Estudos universitários de língua e literatura (Homenagem ao prof. Dr. Leodegário A. de Azevedo Filho). Rio de Janeiro: Tempo Brasileiro, 1993).

2.2.3 GASTÃo, Ana Marques. Blasfémias em claro-escuro. Artigo publicado no Diário de Notícias, de Lisboa, em 11/08/06.

2.2.4 GOMES, Maria dos Prazeres. Leonorana: a escritura em palimpsesto. Artigo publicado na revista Estudos Portugueses e Africanos, de Lisboa, n. 20, julho/dezembro de 1992.

2.2.5 LINO, Pedro Sena. Uma tisana é um texto que refresca a arder. Artigo publicado no jornal Público, de Lisboa, em 15/07/2006.

2.2.5 MACEDO, Ana Gabriela. O ver/ler de Ana Hatherly. In: Interfaces do olhar Uma antologia crítica, Uma antologia poética. Lisboa: Roma Editora, 2004. p. 15-23.

2.2.7 MARTINHO, Fernando J. B. A viagem na poesia de Ana Hatherly: algumas implicações cronotópicas. In: Interfaces do olhar - Uma antologia crítica, Uma antologia poética. Lisboa: Roma Editora, 2004. p. 59-63.

\subsection{Artigos sobre o neobarroco português:}

2.3.1 GUIMARÃES, Fernando. Entre o barroco e o neobarroco. Artigo publicado na revista Claro Escuro. Lisboa: Quase Edições, 1990.

2.3.2 MELO E CASTRO, E. M. As fontes, as nuvens e o caos. Notas sobre o barroco, neobarroco e metabarroco na poesia portuguesa da $2^{a}$. metade do século $X X$, artigo publicado no n. 4/5 da revista Claro Escuro. Lisboa: Quimera edições, 1990.

2.3.3 PEREIRA, Paulo. O neobarroco como nova existência. Artigo publicado na revista Claro Escuro. Lisboa: Quase Edições, 1990.

\subsection{Livros sobre o neobarroco português:}

2.4.1 RUSSO, Vincenzo. Suspeita do avesso. Barroco e neobarroco na poesia portuguesa contemporânea. Vila Nova de Famalicão: Quasi Edições, 2008.

\subsection{Bibliografia geral:}

2.5.1 ASSUNÇãO, Ademir. Cinemitologias. Londrina: Atrito Art Editorial, 2002.

2.5.2 ÁvilA, Affonso: O lúdico e as projeções do mundo barroco. São Paulo: ed. Perspectiva, 1994. 
2.5.3 BENSE, Max. Pequena estética. São Paulo: ed. Perspectiva, 2003.

2.5.4 BORGES, Jorge Luis. História da eternidade. Porto Alegre: Globo, 1984.

2.5.5 BORGES, Jorge Luis. O livro dos sonhos. São Paulo: Difel, 1985.

2.5.6 BORGES, Jorge Luis. O livro dos seres imaginários. Porto Alegre: Editora Globo, 1982.

2.5.7 CAMPOS, Augusto e Haroldo de; PIGNATARI, Décio. Teoria da Poesia Concreta. São Paulo: Duas Cidades, 1965.

2.5.8 CAMPOS, Augusto de. À margem da margem. São Paulo: Companhia das Letras, 1989.

2.5.9 CAMPOS, Haroldo de. A operação do texto. São Paulo: Perspectiva, 1976.

2.5.10 CAMPOS, Haroldo de. A arte no horizonte do provável. São Paulo: Perspectiva, 1977 (Debates, 16).

2.5.11 CAMPOS, Haroldo de. Hagoromo de Zeami. São Paulo: Estação Liberdade, 1993.

2.5.12 CAMPOS, Haroldo de. O arco-íris branco. Rio de Janeiro: Imago, 1997.

2.5.13 CAPRA, Fritjof. O Tao da Física. São Paulo: ed. Pensamento, 1989.

2.5.14 CHIAMPI, Irlemar. Barroco e modernidade. São Paulo: Perspectiva, 1998.

2.5.15 COSTA, Horácio. Mar abierto. Ensayos sobre literatura brasileña, portuguesa y hispanoamericana. México DF: Fondo de Cultura Econômica, 1998.

2.5.16 DESHIMARU, Taisen. A tigela e o bastão. São Paulo: ed. Cultrix, 1983.

2.5.16 DOURADO, Autran. Proposições sobre labirinto. Artigo publicado na revista Colóquio Letras n. 20, julho de 1974.

2.5.17 ECO, Umberto. Obra aberta. São Paulo: Perspectiva, 1976.

2.5.18 ECO, Umberto. Sobre os espelhos e outros ensaios. Rio de Janeiro: Nova Fronteira, 1989.

2.5.19 ECO, Umberto. Os limites da interpretação. São Paulo: Perspectiva, 2008.

2.5.20 FREITAS, Lima de. Das geometrias labirínticas. Revista ICALP, vol. 2/3, 1985, 69-81. 
2.5.21 GOSWAMI, Amit. Universo autoconsciente. Rio de Janeiro: Rosa dos tempos, 1993.

2.5.22 HARVEY, Paul. Dicionário Oxford de literatura clássica grega e latina. Rio de Janeiro: Jorge Zahar Editor, 1987.

2.5.23 HOCKE, Gustav René. Maneirismo: o mundo como labirinto. São Paulo: Perspectiva, 2005.

2.5.24 HUIZINGA, Joahan. Homo ludens. O jogo como elemento da cultura. São Paulo: ed. Perspectiva, 2007.

2.5.25 JAKOBSON, Roman. Lingüística e comunicação. São Paulo: Cultrix / Edusp, 1969.

2.5.26 JOYCE, James. Panaroma do Finnegans Wake. Trad.: Augusto e Haroldo de Campos. São Paulo: Perspectiva, 2001.

2.5.27 JUNG, Carl Gustav. O homem e seus símbolos. Rio de Janeiro: Nova Fronteira, s/d.

2.5.28 KOSTELANETZ, Richard. Novos rumos das artes. Rio de Janeiro: Lidador, 1967.

2.5.29 LAUTRÉAMONT. Obras completas. Trad.: Claudio Willer. São Paulo: ed. Iluminuras, 2005.

2.5.30 LEMINSKI, Paulo. Bashô, A lágrima do peixe. São Paulo: ed. Brasiliense, 1983.

2.5.31 MALlarmÉ, Stéphane. Poemas. Trad.: Augusto e Haroldo de Campos. São Paulo: Perspectiva, 1980.

2.5.32 MARX, Karl, e ENGELS, Frederich. Sobre literatura e arte. São Paulo: Global Editora, 1980.

2.5.33 MILÁN, Eduardo. Estação da fábula. São Paulo: Fundação Memorial da América Latina, 2001.

2.5.34 MOISÉS, Massaud. Dicionário de termos literários. São Paulo: ed. Cultrix, 2004.

2.5.35 MOLES, Abraham. Teoria da informação e percepção estética. Rio de Janeiro: Tempo Brasileiro, 1969.

2.5.36 PERLOFF, Marjorie. O momento futurista. São Paulo: Edusp, 1993.

2.5.37 PINHEIRO, Amalio. Máquina e imaginário: o desafio das poéticas imaginárias. São Paulo: Edusp, 1993. 
2.5.38 PIVA, Roberto. Um estrangeiro na legião. São Paulo: Globo, 2005.

2.5.39 POUND, Ezra. A arte da poesia. São Paulo: Cultrix, 1988. Trad.: Heloysa de Lima Dantas e José Paulo Paes.

2.5.40 REHERMANN, Carlos. El hacha de dos filos. Artigo publicado na revista Insomnia n. 77, de Montevidéu, em 18/06/1999.

2.5.41 SHANKARA. A jóia suprema do discernimento. São Paulo: ed. Pensamento, 1992.

2.5.42 SILVA, Georges, e HOMENKO, Rita. Budismo: psicologia do autoconhecimento. São Paulo: Pensamento, 1993.

2.5.43 SILVA, Rogério Barbosa. Ana Hatherly: uma poesia em mutação. Artigo publicado na revista Et Cetera, de Curitiba, 2006, 156-161.

2.5.44 SPINA, Segismundo: Presença da literatura Portuguesa I (Era medieval). São Paulo: Difusão européia do livro, 1974.

2.5.45 VÁRIOS AUTORES. The Tormont Webster's Illustrated Encyclopedic Dictionary. Montreal: Tormont Publications Inc., 1990.

\section{Bibliografia passiva}

\subsection{Sobre o experimentalismo português e as vanguardas}

3.1.1 CRUZ, Gastão. A poesia portuguesa hoje. 2a . Ed. ver. E aum. Lisboa: Relógio D’Água, 1999.

3.1.2 DIOGO, Américo Lindeza. Linguagens de fazer, afazeres sem linguagem. Poesia experimental, Nuno Júdice, Herberto Helder. Braga: APPACDM, 1997. (Col. Cadernos do Povo - Ensaio).

3.1.3 GUIMARÃES, Fernando. A poesia contemporânea e o fim da modernidade. Lisboa: Editorial Caminho, 1989 (Col. Estudos da Literatura Portuguesa).

3.1.4 MELO E CASTRO, E. M. Dialética das vanguardas. Lisboa: Livros Horizontes, 1976.

3.1.5 MELO E CASTRO, E. M. Literatura de invenção. São Paulo: Difel, 1984.

3.1.6 MELO E CASTRO, E. M. As vanguardas na poesia portuguesa do século $X X$. Lisboa: Instituto de Cultura e Língua Portuguesa, 1987 (Biblioteca Breve; 52). 


\subsection{Sobre o barroco}

3.2.1 ÁVILA, Affonso. Barroco: teoria e análise. São Paulo: Perspectiva, 1997

3.2.2 BENJAMIN, Walter. Origem do drama barroco alemão. Trad. Sérgio Paulo Rouanet. São Paulo: Brasiliense, 1984.

3.2 3 CALABRESE, Omar. A idade neobarroca. Lisboa: Edições 70, s.d.

3.2.4 CAMPOS, Haroldo de. O seqüestro do barroco na formação da literatura brasileira: o caso Gregório de Matos. Salvador: Casa de Jorge Amado, 1989.

3.2.5 DELEUZE, Gilles. A dobra - Leibniz e o barroco. Campinas: Papirus, 1991.

3.2.6 FUENTES, Carlos. O espelho enterrado. Rio de Janeiro: Rocco, 2001.

3.2.7 GOMES, Maria dos Prazeres. "Barroco e poesia experimental: um diálogo de dois gumes”. In: MARQUES, Reinaldo; BITTENCOURT, Gilda N. (org.). Limiares críticos: ensaios sobre literatura comparada. Belo Horizonte: Autêntica, 1998. 195-206.

3.2.8 ROBAYNA, Andrés Sánchez. O barroco da leveza. In: Revista USP. São Paulo, n. 8, dez.1990-fev.1991, pag. 135-140.

3.2.9 SARDUY, Severo. Barroco. Lisboa: ed. Vega, 1989.

\subsection{Antologias de poesia portuguesa contemporânea}

3.3.1 MELO E CASTRO, E. M., e MENÉRES, Maria Alberta. Antologia da novíssima poesia portuguesa. Lisboa: Moraes Editora, 1971.

3.3.2 MENÉRES, Maria Alberta. Antologia da poesia portuguesa: 1940-1977. Lisboa: Moraes Editora, 1979.

3.3.3 MENÉRES, Maria Alberta. Antologia da novíssima poesia portuguesa. Lisboa: Moraes Edit., 1962 (Círculo de Poesia; 15).

\subsection{Teoria literária e obras de caráter geral}

3.4.1 ÁVILA, Carlos. Poesia e sociedade de consumo. In: COSTA, Horácio (org.) A palavra poética na América Latina. São Paulo: Fundação Memorial da América Latina, 1992, p. 109118.

3.4.2 BARRENTO, João. A espiral vertiginosa - ensaios sobre a cultura contemporânea. Lisboa: Edições Cotovia, 2001.

3.4.3 CAMPOS, Haroldo de. Poesia e modernidade: da morte do verso à constelação. $O$ poema pós-utópico. O arco-íris branco. Rio de Janeiro: Imago, 1997. 
3.4.4 MELO E CASTRO, E. M. Entre o oral $e$ o visual: uma rede de traduções intersemióticas. In: SEIXO, Maria Alzira (coord.). Poéticas do século XX. Lisboa: Livros Horizontes, 1984. P. 83-95.

3.4.5 MELO E CASTRO, E. M. Vôos da fênix crítica. Lisboa: Edições Cosmos, 1995.

3.4.6 COHEN, Nissim. Dhammapada - A senda da virtude. São Paulo: Palas Athena, 1985.

3.4.7 COMPAGNON, A. Os cinco paradoxos da modernidade. Trad. Cleonice Mourão et alli. Belo Horizonte: UFMG, 1996.

3.4.8 DIOGO, Américo Lindeza. Modernismos, pós-modernismos, anacronismos: para uma história da poesia portuguesa recente. Lisboa: Ed. Cosmos, 1993.

3.4.9 GRUZINSKI, Serge. Pensamento mestiço. São Paulo: Companhia das Letras, 2001.

3.4.10 JAMESON, Frederic. “Teorias do pós-moderno”; “Transformações da imagem na pósmodernidade”. In: _ Espaço e imagem: teorias do pós-modernismo e outros ensaios. Org. e trad. Ana Lúcia Almeida Gazzola. Rio de Janeiro: Editora UFRJ, 2004. p. 31-45; p. 129-161.

3.4.11 PAZ, Octavio. Los hijos del limo. Barcelona: Seix Barral, 1989. (Os filhos do barro. Trad. Olga Savary. Rio de Janeiro: Nova Fronteira, 1984.)

3.4.12 PÉCORA, Alcir. Máquina de gêneros. São Paulo: Edusp, 2001.

3.4.13 PIMENTA, Alberto. O silêncio dos poetas. Lisboa: Edições Cotovia, 2005.

3.4.14 RIPELLINO, Ângelo Maria. Maiakovski e o teatro de vanguarda.. São Paulo: Perspectiva, 1971. 
